CREATING INCUBATOR NEIGHBOURHOOD PERFORMING ARTS VENUES

IN THE CITY OF VANCOUVER USING GROWTH FINANCING TOOLS

by

David Godin

Bachelor of Arts, Political Science, 2008, Simon Fraser University

Bachelor of Arts, History, 2008, Simon Fraser University

Associate of Arts, 2005, Langara University College

A MRP presented to Ryerson University

in partial fulfillment of the

requirements for the degree of

Master of Planning

in the Program of

Urban Development

Toronto, Ontario, Canada, 2013

(C) David Godin 2013 


\section{AUTHOR'S DECLARATION FOR ELECTRONIC SUBMISSION OF A MRP}

I hereby declare that I am the sole author of this MRP. This is a true copy of the MRP, including any required final revisions.

I authorize Ryerson University to lend this MRP to other institutions or individuals for the purpose of scholarly research.

I further authorize Ryerson University to reproduce this MRP by photocopying or by other means, in total or in part, at the request of other institutions or individuals for the purpose of scholarly research.

I understand that my MRP may be made electronically available to the public. 


\title{
CREATING INCUBATOR NEIGHBOURHOOD PERFORMING ARTS VENUES USING GROWTH FINANCING TOOLS
}

(C) David Godin 2013

Master of Planning

Urban Development

Ryerson University

\begin{abstract}
A recommendation that Vancouver City Council implement the Culture Plan's commitment to address the persisting insufficiency of small rental performing arts venues by using Community Amenity Contributions (CACs) from the rezoning of properties to fund the creation of small, inexpensive 'incubator' neighbourhood performing arts venues, which are critical to the health and development of the performing arts community. The recommended development model is based on Havana Theatre; a small incubator performing arts venue located inside Havana Restaurant, which subsidizes the cost of operating the venue. In downtown, developers will build the venues and attached retail space using in-kind CACs. Outside of downtown, a 'renovation-first' approach will be taken by the City to buy existing buildings using accrued CACs and renovate them to create the venues and attached retail space. On the strength of experience and business plan, the City will select qualified bidders to operate the venues and attached businesses.
\end{abstract}

Key Words:

Planning; Culture; Exactions; Growth Financing Tools; Vancouver. 


\section{ACKNOWLEDGEMENTS}

I would like to begin by thanking Professor David Amborski for his assistance as supervisor for this MRP, and I want to convey my sincere appreciation for the time he took to sit down with me to talk about the Masters of Planning program, my background, interests, and professional goals, prior to my application to Ryerson. I would also like to thank Professor Mitch Kosny for his assistance as second reader for my MRP, and for the opportunity to be his Graduate Assistant twice during my Masters. It was a high-point of my experience at Ryerson and I am grateful to have found a mentor and friend. I want to also thank all my friends and classmates. I am proud of everyone and these two years together have been some of the best of my life.

Thank you to Scot Hein, of the City of Vancouver, for his mentorship and support and the opportunity for a practicum at the City. Thank you to Randy Pecarski, of the City of Vancouver, for his assistance with my Growth Financing background research, and Michael Gordon, also with the City, for his encouragement to apply to planning school and the introduction to Professor Amborski. I must thank Paul Sontz and Mae Whyte of Tourism Vancouver for their support and assistance with my performing arts venue research. Thank you to Bill Millerd, Howard Jang, Peter Chapek, Laura Eveleigh, and co-workers at the Arts Club Theatre Company, for their tremendous encouragement to pursue my passion for planning and make it my career. Without them I would not have had the spark for this MRP. I will carry forward my love of theatre and the performing arts into my career and work to help culture flourish in our city.

To my parents Nancy Strider and Michael Godin, my father's husband Eddy Fisher, and Charlie and Debbie Vanditmars, I want to profoundly thank them for all of their support, love, and encouragement to pursue planning, apply to graduate school, and move to Toronto to follow my dream of having the career I want. Most importantly, I must thank Jessica Vanditmars. My partner, my love; thank you for believing in me and us enough to come to cold, humid, windy, and confusing Toronto for two years so that I can pursue my dream career of being a planner. I could not have done this without you, and from the bottom of my heart I thank you. 


\section{Table of Contents}

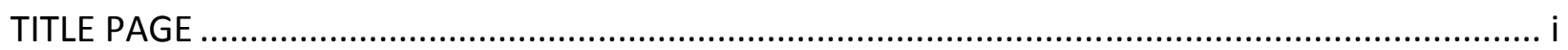

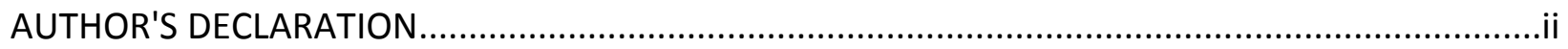

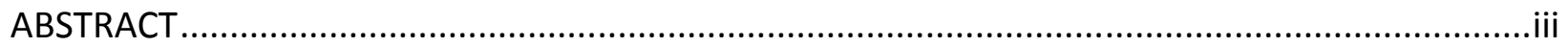

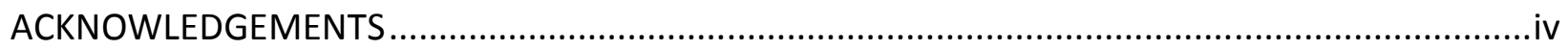

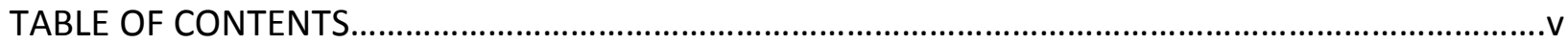

POLICY REPORT: CULTURAL PLANNING, DEVELOPMENT AND BUILDING .............................. 1

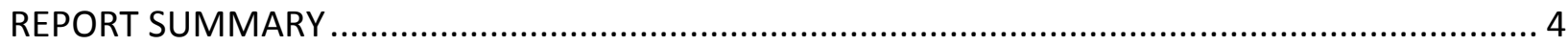

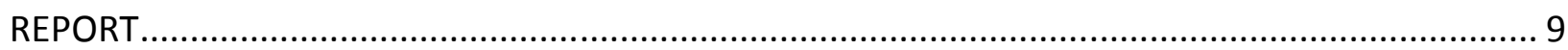

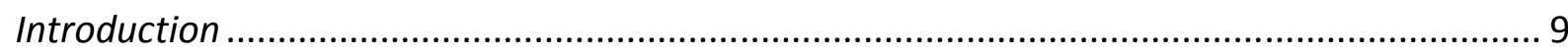

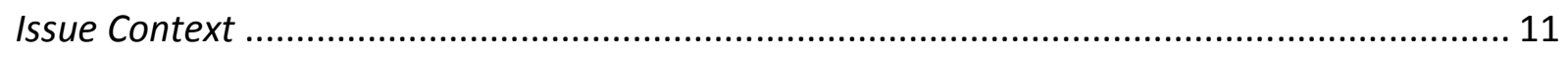

The Importance of incubator Performing Arts Venues.................................................... 14

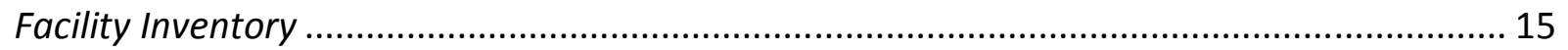

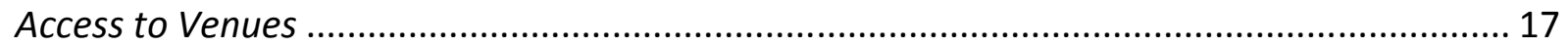

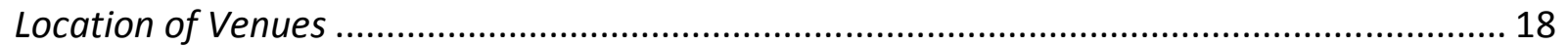

Review of Growth Financing Tools - Development Cost Levies ......................................... 20

Review of Growth Financing Tools - Community Amenity Contributions .............................. 22

Proposal - Precedent for Incubator Neighbourhood Performing Arts Venues ....................... 24

Proposal - The Havana Theatre Model ............................................................................. 25

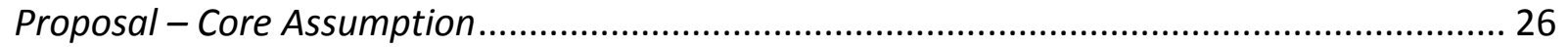

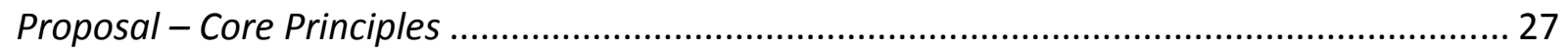

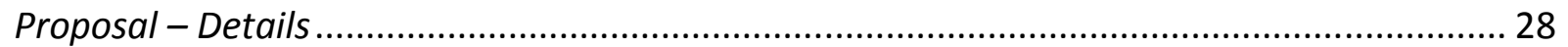

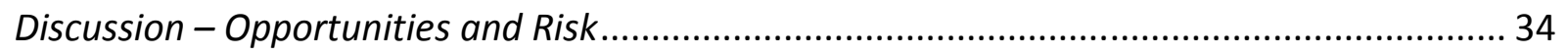

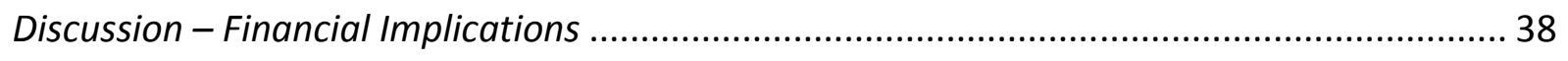

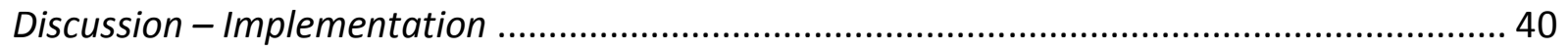

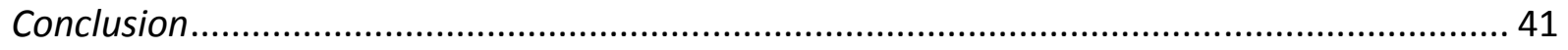

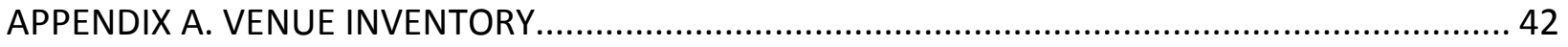

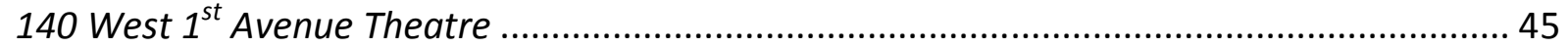

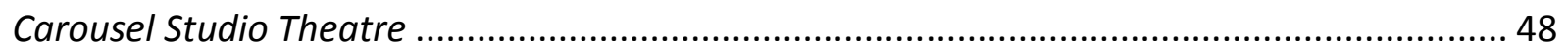

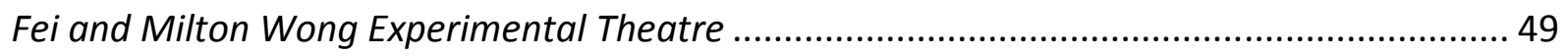

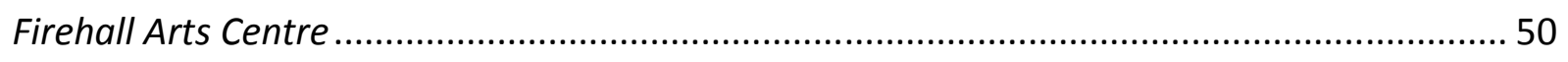

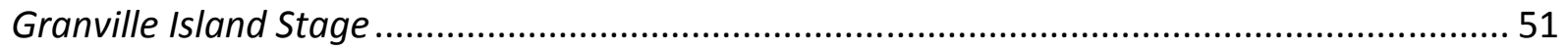




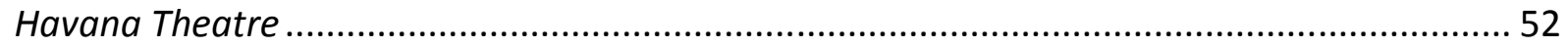

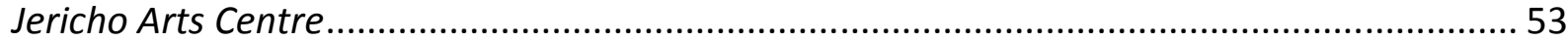

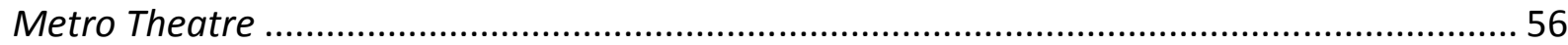

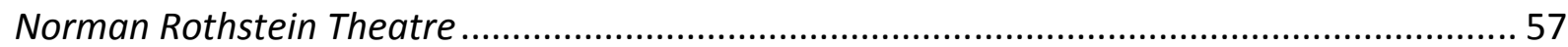

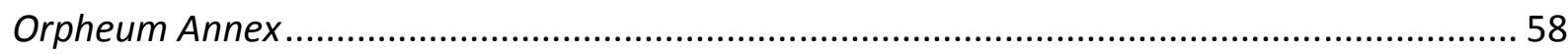

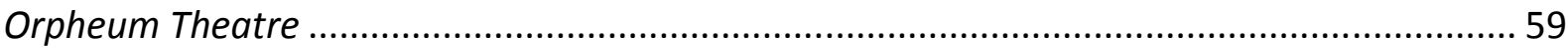

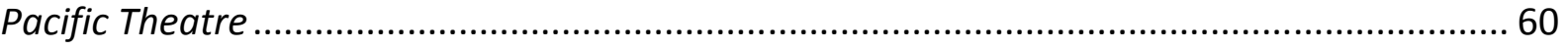

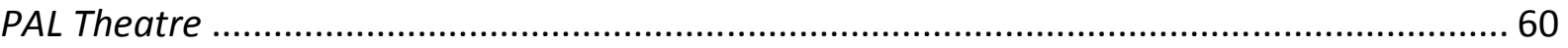

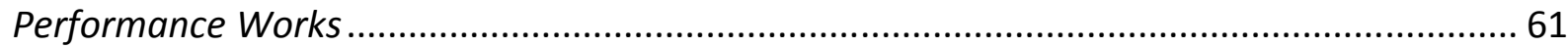

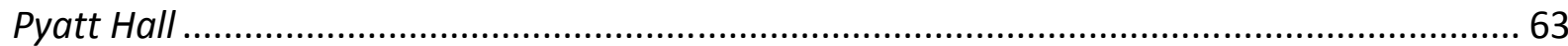

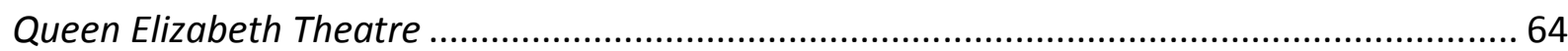

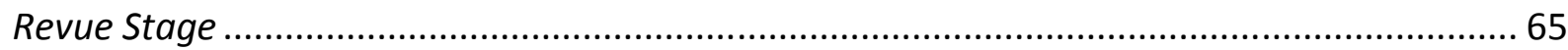

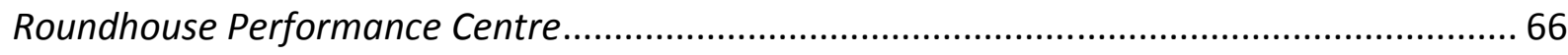

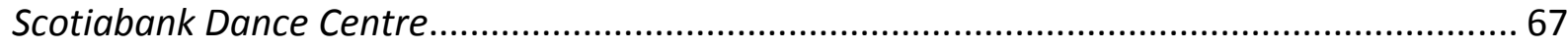

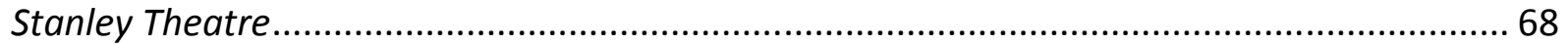

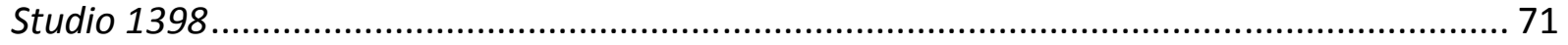

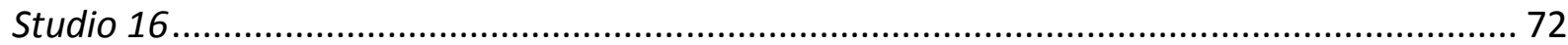

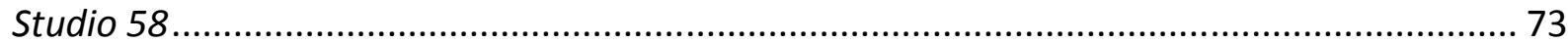

The Centre in Vancouver for Performing Arts ............................................................ 74

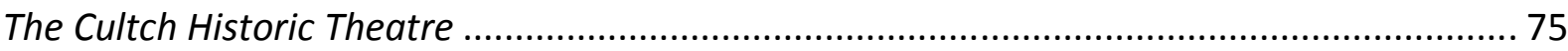

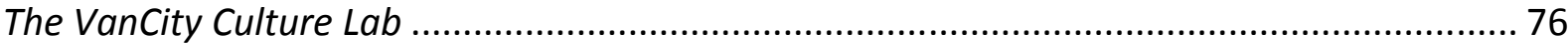

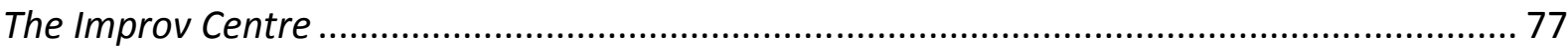

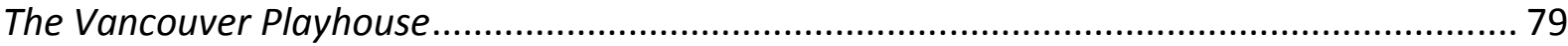

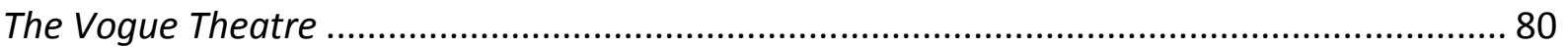

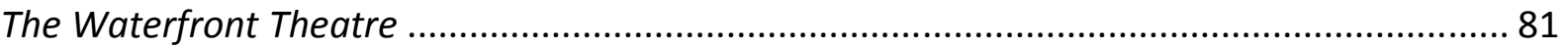

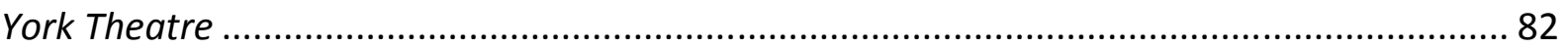

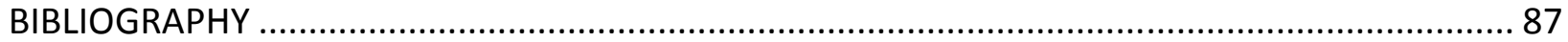




\section{TABLES}

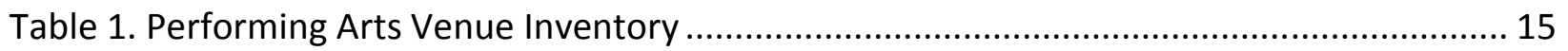

Table 2. Incubator Performing Arts Venues. ........................................................................... 24

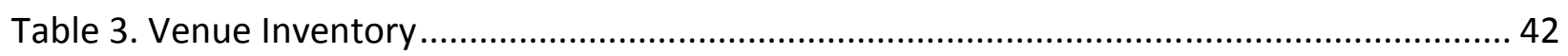

\section{FIGURES}

Figure 1. Map of Performing Arts Venues in the City of Vancouver .................................... 18

\section{PLATES}

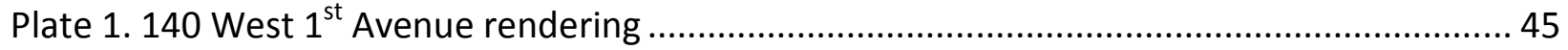

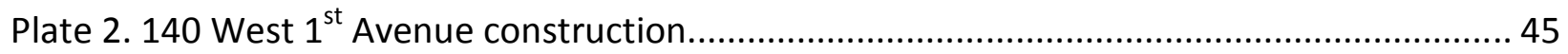

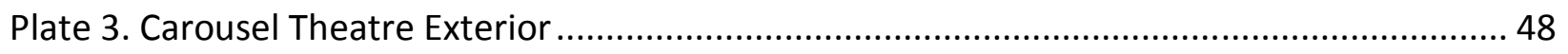

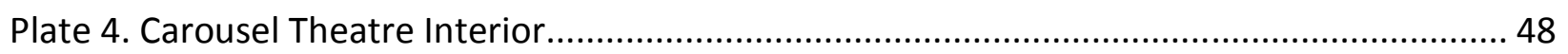

Plate 5. Simon Fraser University School for the Contemporary Arts, Exterior........................... 49

Plate 6. Fei and Milton Wong Experimental Theatre, Interior ............................................... 49

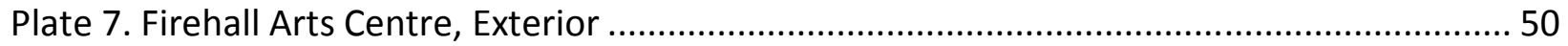

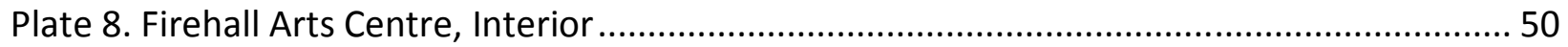

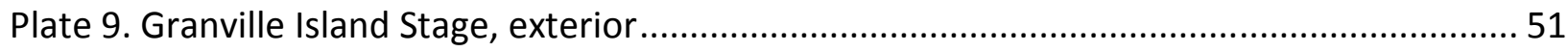

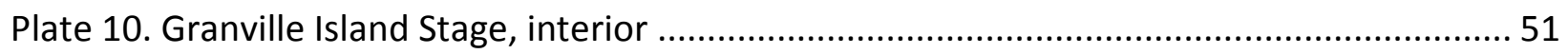

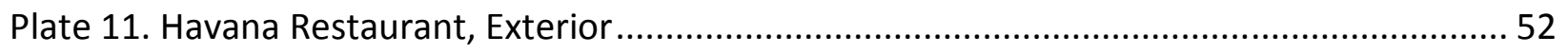

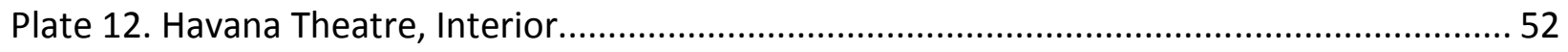

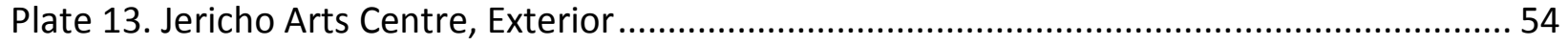

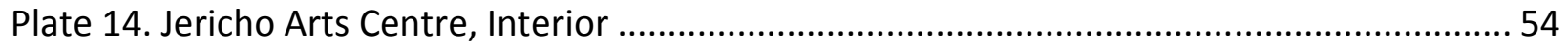

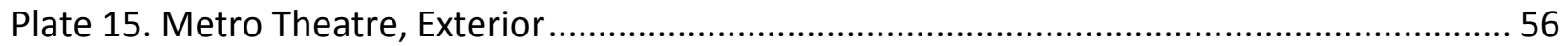

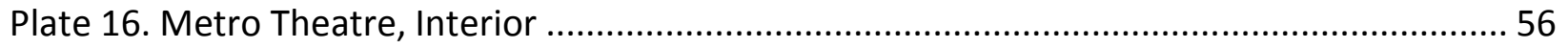

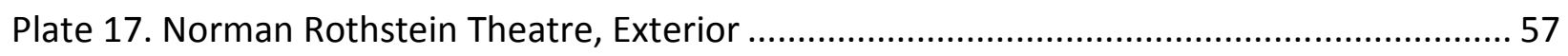

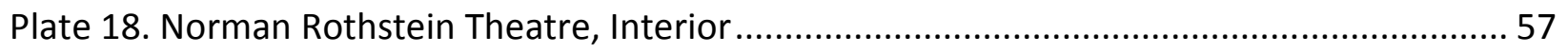

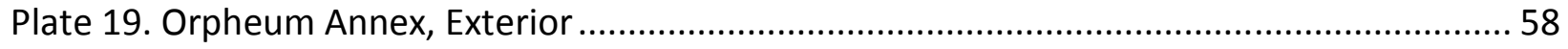

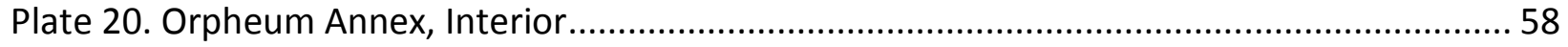

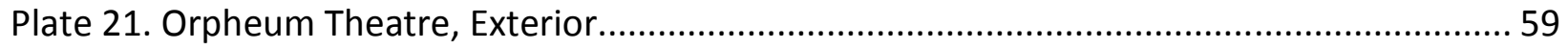

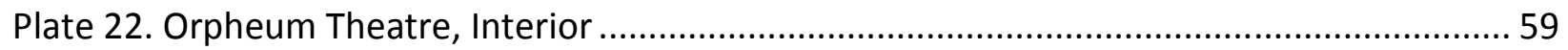




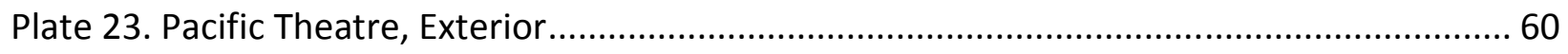

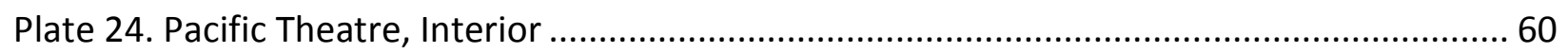

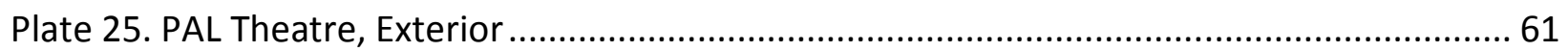

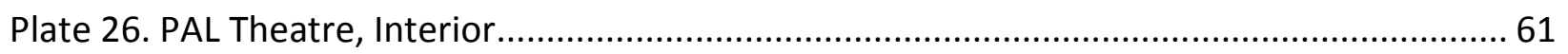

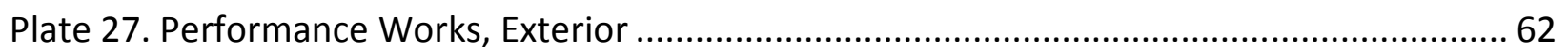

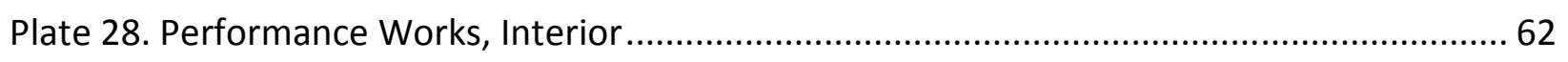

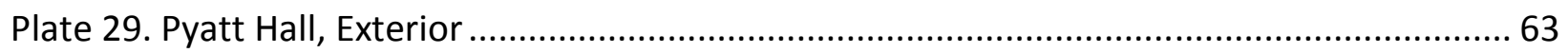

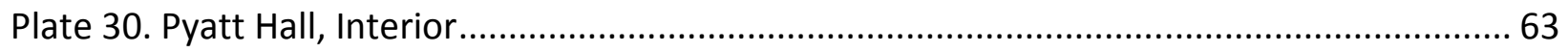

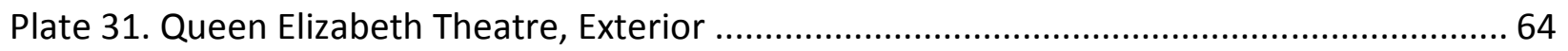

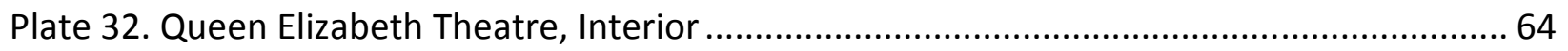

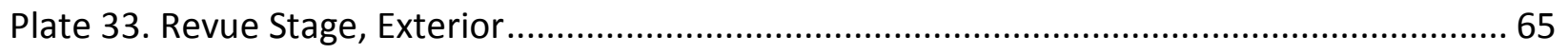

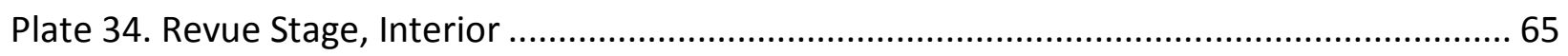

Plate 35. Roundhouse Performance Centre, Exterior ............................................................ 66

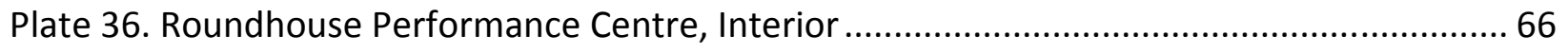

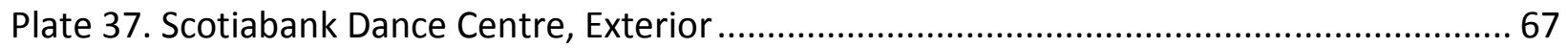

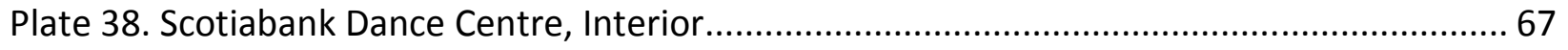

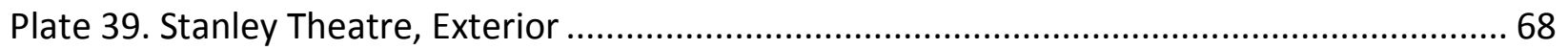

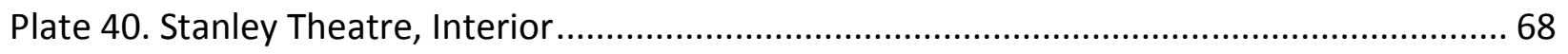

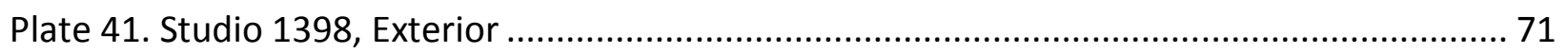

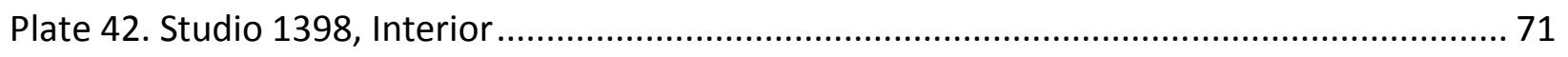

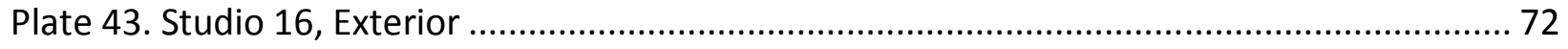

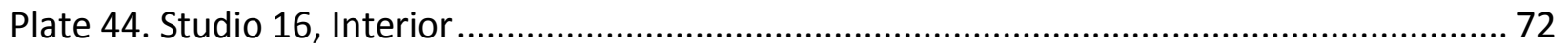

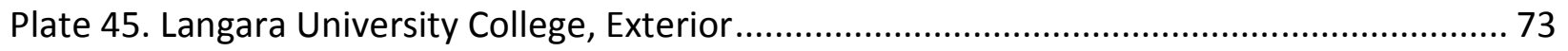

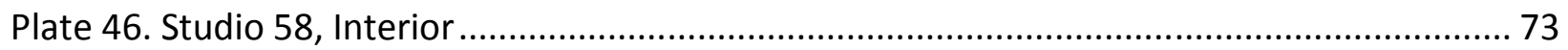

Plate 47. The Centre in Vancouver for Performing Arts, Exterior ......................................... 74

Plate 48. The Centre in Vancouver for Performing Arts, Interior ............................................. 74

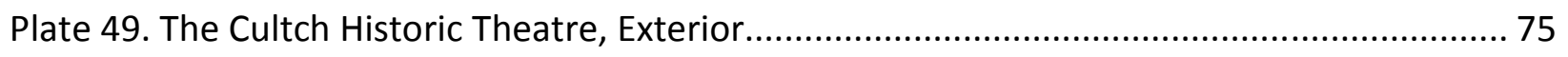

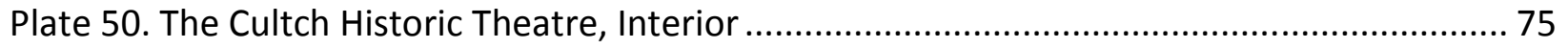

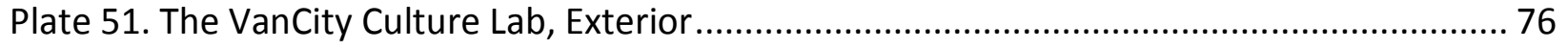

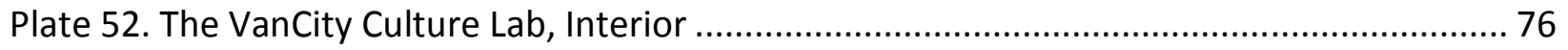

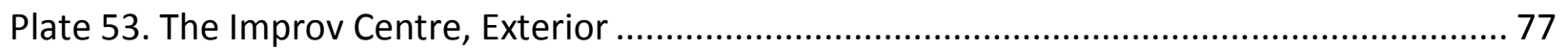

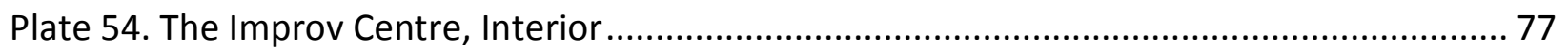

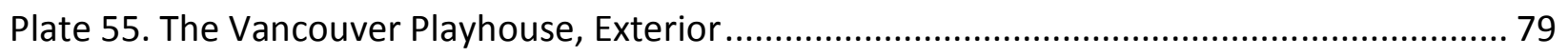




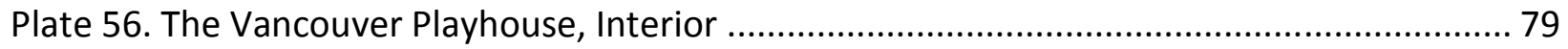

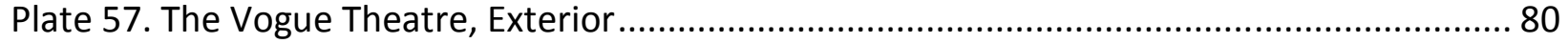

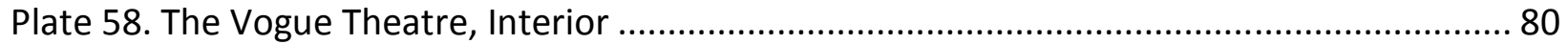

Plate 59. The Waterfront Theatre, Exterior ........................................................................... 81

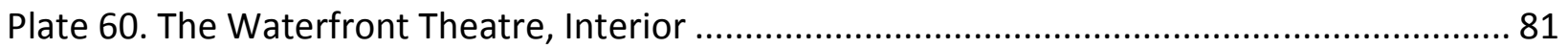

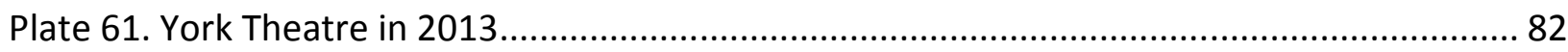

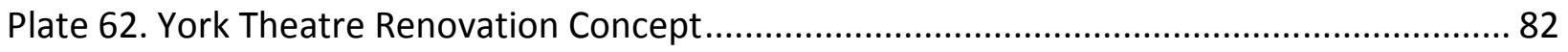

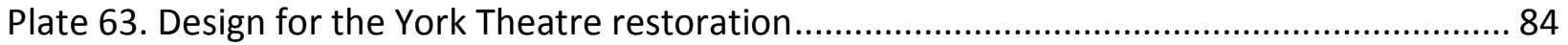

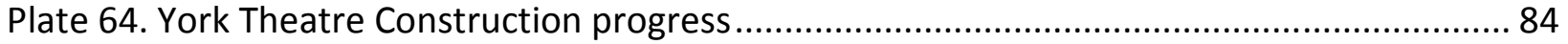




\section{POLICY REPORT: \\ CULTURAL PLANNING, DEVELOPMENT AND BUILDING}

Report Date: $\quad$ April $16^{\text {th }}, 2013$

Contact: David Godin

Contact No: $\quad$ 416-710-2570

Contact Email: dgodin@ryerson.ca

TO: $\quad$ Vancouver City Council

FROM: David Godin, Master of Planning, Urban Development (Candidate 2013)

School of Urban and Regional Planning, Ryerson University, Toronto

\section{SUBJECT: Creating Incubator Neighbourhood Performing Arts Venues Using Growth} Financing Tools

\section{RECOMMENDATION}

A. THAT Council receive the Creating incubator Neighbourhood Performing Arts Venues Using Growth Financing Tools report as information pertaining to Creative City, The Culture Plan for Vancouver, Financing Growth, and Local Area Planning.

B. THAT Council refer the report to the Managing Director, Cultural Services; the Co-Director, Policy, Planning and Infrastructure, Office of Cultural Affairs; the General Manager, Planning and Development; the General Manager, Real Estate and Facilities; and the City's Solicitor;

FURTHER THAT Council direct staff to report back with an implementation plan.

C. THAT in light of the completion of new and renovated performing arts venues since the Culture Plan was approved, and changes to the composition of the local performing arts sector as a result of decreased funding and the 'Great Recession', Cultural Services staff should update the Culture Plan research data to confirm that demand remains for additional small performance venues; 
D. THAT upon confirmation that demand remains for small performing arts spaces, Council adopt as Policy an implementation plan that creates incubator neighbourhood performing arts venues based the Havana Theatre model using the following principles:

i. Simple 'black box' performing arts venues with a capacity of 140 seats or less.

ii. A streamlined facility rental process and commitment to minimize rental fees.

iii. Each neighbourhood in the city will eventually receive a venue.

iv. Community Amenity Contributions (CACs) will be used to secure capital.

v. In the Central Area, in-kind CACs will be used to deliver venues on-site.

vi. Outside of the Central Area, accrued cash-in-lieu CACs will be used to deliver venues following a renovation-first approach that prioritizes the purchase and conversion of suitable buildings that would also have space for compatible revenue-generating commercial leases.

vii. The City of Vancouver Real Estate Division, operating on behalf of the Property Endowment Fund, would coordinate its investments with Cultural Services and the Planning Department to ensure that strategic buildings in a neighbourhood that would be suitable for later conversion to incubator performing arts venues would be optioned or purchased to protect them from redevelopment until sufficient CAC money has been accrued.

viii. Venues will be universally-accessible, energy efficient, and located on transit routes within established neighbourhood commercial areas.

ix. The City will retain ownership while competitively-chosen non-profit groups will operate the venues and associated businesses. 
E. THAT the Culture Plan Implementation Phase 1 - 2008-2023 Cultural Facilities Priorities Plan is amended to commit the City to purse the creation of new incubator neighbourhood performing arts venues.

FURTHER THAT the Cultural Plan 2008 - 2018, Section 3.4 Vancouver - A Creative City: Neighbourhoods, is amended to include the creation of new incubator neighbourhood performing arts venues. 


\section{REPORT SUMMARY}

In 2008, Vancouver City Council adopted a Culture Plan to support the city's rapidly growing cultural sector. The Culture Plan commits the City to addressing the persisting insufficiency of small performing arts venues that available for rent, despite the recent increase in the pace of construction and renovation of cultural facilities. Small, inexpensive live performing arts rental venues in neighbourhoods throughout the city are critical to the health and growth of Vancouver's performing arts community. These venues 'incubate' new companies by offering an affordable starting point for them to present their work and attract an audience. Once a company has produced successful shows in small 'incubator' performing arts venues it may advance along the venue continuum to larger spaces with additional seats and technical capacity. Without access to small incubator venues, new performing arts companies must prematurely begin renting larger venues and expose themselves to significant financial risk if they cannot attract an audience. Unsuccessful shows in a small incubator venue are a setback for a new company, but when it occurs in a large venue the financial burden is crippling and the company will likely fail, leaving its founders in difficult financial circumstances and the performers, technicians, and staff without work. In time, some of the successful small companies will grow and hire more performers and employees, secure permanent premises, and produce artistic work that enriches the lives of the performers and audiences, all while fostering local economic activity and positively influencing the city's reputation and character.

Incubator performing arts venues are generally simple 'black box' theatres that have no permanent stage; fewer than 140 seats, which may often be reconfigured from one show to the next; rudimentary lighting and sound equipment; and the ability to accommodate different types of performing arts and the display of artwork. While several incubator performing arts venues exist in Vancouver, including Havana Theatre, the PAL Theatre, and Studio 1398. Incubator performing arts venues are financially challenging to operate because of their limited seating, and they are difficult to create due to the difficulty accessing capital, regulatory and licensing barriers, expensive commercial lease rates, and the ongoing development pressure on suitable buildings in desirable neighbourhoods. 
It is the recommendation of this report that the City of Vancouver should commit to creating an incubator performing arts venue in each of the Vancouver's neighbourhoods using a model that will utilize capital secured as a public benefit through Community Amenity Contributions (CACs) from the rezoning of nearby properties. In the Central Area (downtown) of the city, in-kind CACs will allow the incubator performing arts venue to be built on-site in new developments. In the rest of the city, a renovation-first approach will utilize cash-in-lieu CACs from rezonings in the neighbourhood to purchase existing buildings in established commercial areas and renovate them to create the incubator performing arts venues and an attached commercial retail unit. Non-profit organisations will be selected through a competitive tenant call process to run each venue and the attached commercial retail unit, the revenue from which will be used to internally subsidize venue operating costs. Such an internal subsidy has been successfully used for 17 years to run the privately-owed Havana Theatre, Gallery, and Restaurant on Commercial Drive in the Grandview-Woodlands neighbourhood of the City of Vancouver.

No additional policy or revenue tools are required to proceed with the creation of incubator neighbourhood performing arts venues using this model and there is extensive local precedent for using Community Amenity Contributions to finance the creation or restoration of cultural facilities. Recent examples include:

- The Arts Club Theatre Company's Stanley Industrial Alliance Stage;

- The Vancouver East Cultural Centre's York Theatre;

- The Vancouver Symphony Orchestra School of Music's Pyatt Hall;

- The Vancouver International Film Festival's International Film Centre;

- The Performing Arts Lodge's PAL Theatre;

- Simon Fraser University's Fei and Milton Wong Experimental Theatre;

- The City of Vancouver's Orpheum Annex Theatre;

- The City of Vancouver's 140 West $1^{\text {st }}$ Ave Theatre. 


\section{CULTURAL POLICY}

- 1987, Council adopts The City's Cultural Goals, which made a commitment to ensuring the existence of sufficient facilities to make and present art in the City of Vancouver. (City of Vancouver, 2008)

- 1990, Council adopts a 10-year Cultural Faculties Priority Plan, which included a renewed commitment to the operation of the municipally-owned Civic Theatres (Orpheum Theatre, Queen Elizabeth Theatre, and the Vancouver Playhouse) and the planning of renewal and upgrades to the venues through a significant future capital investment. (City of Vancouver, 2008)

- 1995, Council adopts Artist Live/Work Review in support of The City's Cultural Goals of ensuring that a variety of production spaces for arts exist in the city, including legal allowance for studio space, retail sales, and inventory within residential dwellings. (City of Vancouver, 2008)

- 2008, Council adopts a new 2008-2018 Culture Plan for Vancouver, which "sets out the vision and strategic direction to ensure Vancouver's place as a Creative City". It also committed the City to undertaking a complete inventory of all existing rehearsal and performance spaces located in public, non-profit, and private facilities. (City of Vancouver, 2008)

- 2008, Council adopts the Cultural Plan Implementation Phase 12008 - 2023 Cultural Facilities Priorities Plan. This Far-reaching policy document commits the City to an energetic period of cultural development, including goals for the creation and preservation of cultural facilities. This plan identified key gaps and areas of focus for developing cultural facilities in the city, including the need to create additional smaller performance venues. (City of Vancouver, 2008)

- 2008, Council adopts the Cultural Plan Implementation Phase 1 - Cultural Tourism Strategy. This policy informs roles, responsibilities, and investment decisions in cultural tourism and partners the City with Tourism Vancouver to develop a Tourism Master Plan for the city. (City of Vancouver, 2013) 


\section{PLANNING AND DEVELOPMENT POLICY}

- 1993, Council adopts Transfer of Density Policy and Procedure. This framework allows developable density to be transferred from one site to another under a variety of circumstances. (City of Vancouver, 2012)

- 2003, Council adopts Heritage Building Rehabilitation Program Policies and Procedures. This policy updates the City's ability to enter into Heritage Restoration Agreements in which the building owner is compensated for the cost of restoring the structure through the permanent transfer of their developable density to a recipient site where it is treated as bonus density. (City of Vancouver, 2012)

- 2003, Council adopts City-wide Financing Growth policy and set a framework for how Development Cost Levies will be collected and allocated. (City of Vancouver, 2012)

- 2004, Council adopts Financing Growth: Paying for City Facilities to Serve a Growing Population: The role of City-Wide Charges on New Development. This updates the existing growth financing policy with new city-wide and area-specific Development Cost Levies. (City of Vancouver, 2004)

- 2006, Council adopts Community Amenity Contributions through Rezonings. This significant piece of legislation is effectively a land value capture tool and it allows the City to receive most of the value of the land-lift that is created when Council approves an upward change in zoning of a property. (City of Vancouver, 2011)

- 2009, Council adopts Transfer of Density Program and Heritage Building Rehabilitation Program Review. The temporary moratorium on the transfer of density into the 'Heritage Density Bank' was intended to allow accrued density to be landed in new development projects. This will lower the outstanding density in the bank and increase the value of remaining the density. The redevelopment of the York Theatre received special Council permission to bypass the moratorium. (City of Vancouver, 2012)

The proposed model presents creates numerous opportunities and exposure to certain risks, which can be mitigated by careful scrutiny on the part of the City during the tenant call and bidder selection process. The City's Solicitor and legal department will need to draft careful 
contracts and operating agreements and determine through what mechanisms enforcement will be pursued if an operator fails to live up to the agreement. The City's financial exposure and investment will vary from one venue to the next. In an area with a high rate of redevelopment and steady CAC revenue stream, it is likely that the City will not be required to deploy any non-CAC capital. In areas with slow rates of development the City may be required to utilize the resources of its Real Estate department to purchase a property for the venue and deploy capital from the Capital Plan in order to meet the Cultural Facilities Priorities Plan 20082023 end date.

The proposed plan for creating incubator neighbourhood performing arts venues can be implemented immediately. Staff in the Planning Department's Rezoning Centre would have the ability to begin negotiating in-kind CACs that would be used to build on-site incubator neighbourhood performing arts venues in the Central Area and cash-in-lieu CACs to be used under the renovation-first approach to creating venues in the rest of the City. The City's Real Estate Department would begin identifying candidate buildings that met the requirements of incubator neighbourhood performing arts venues. 


\section{REPORT}

\section{Introduction}

In 1986, the City of Vancouver hosted a successful World's Fair. This, and a subsequent influx of emigrants from Hong Kong, initiated a sustained period of growth and physical change that continues to the present. Considerable attention and interest has focused on the City's use of a highly discretionary, urban design-led planning and development model that prioritizes collaboration between the City and the private sector and the receipt of significant public benefits in exchange for rezoning and development permission (Sandercock, 2006) (Punter, 2003). The years since 'Expo86' have been defined by the transformation of much of the downtown waterfront from industrial uses into parks and waterfront promenades, while the internationally-recognized "Vancouverism" style of architecture and development planning emerged as a more than one hundred iterations of tall, slender glass residential point towers with townhouse podiums were built (Punter, 2003) (Boddy, 2005) (Berelowitz, 2005). This period of growth culminated in the hosting of the 2010 Vancouver Winter Olympic Games and its lasting physical legacy of the SkyTrain Canada Line rapid transit connection to the airport and City of Richmond, a new downtown convention centre with a spectacular green roof, and a real estate boom in the Southeast False Creek sub-neighbourhood.

What was less visible during this period of physical change was the renaissance that was under way in the performing arts community and the city's broader cultural sector. While tremendous investment has been made in the construction and renovation of medium and large-sized performing arts venues and cultural facilities, what has been partially overlooked are the small but critically important incubator performing arts venues. These spaces nurture new companies through their affordable rents and flexible interiors that can be used for theatre, dance, music, and experimental mixed-media. The performing arts community needs these spaces and the City of Vancouver has concluded that they are unlikely to be forthcoming from the private or non-profit sectors without City policy and direct intervention and partnership. However, the capacity already exists to cost-effectively create new incubator performing arts venues and 
improve the geographic equity of live entertainment options in neighbourhoods throughout the city. The City's Financing Growth policies allow for capital for these venues to be raised via Community Amenity Contributions from the rezoning of properties in a neighbourhood. This financing mechanism has already been used successfully to help deliver cultural facilities and performing arts venues of a range of size and no additional policies or by-laws are required. 


\section{Issue Context}

Since the mid-1990s, the success of the Guggenheim-Bilbao Museum in Spain has ignited a global trend of investment in cultural facilities - museums, concert halls, theatres, and performing art centres - as a means of local economic development (Woronkowicz, et al., 2012) (Plaza, 2007). In Bilbao, the local economy received a boost as a sustained increase in tourism to the small city was induced by the new museum and its daring Frank Gehry-designed architecture. Property values surged and business in unrelated sectors of the economy experienced a lift. The phenomenon of fostering local economic development through investment in cultural facilities is known as the Bilbao Effect (Plaza, 2007).

Woronkowicz, et al, (2012) of the University of Chicago have noted a significant increase in the pace of investment in cultural facilities throughout the United States during the late 1990s and the 2000s. They also note that with considerable frequency the performing arts centres and concert halls that were built during this period were the host community's first purpose-built, modern cultural buildings. The authors caution municipalities about allowing over-investment in large cultural facilities that cannot be adequately supported by local audiences and existing funding tools, and they find that cities with an array of small and medium venues have a greater likelihood of being able to support the large 'signature' or 'iconic' cultural facilities that have been built in the spirit of the Bilbao Effect (Woronkowicz, et al., 2012). In Canada, a similar trend of investment in cultural facilities occurred and the cautionary note about over-building is transferable. In Toronto, eight significant new cultural facilities were built - or substantially renovated - during the cultural facilities boom and these house the Art Gallery of Ontario, the Royal Ontario Museum, the National Ballet School, the Bata Shoe Museum, the Gardiner Museum of Ceramic Art, the Toronto Film Festival, and the Four Seasons Centre for the Performing Arts (Stanwick \& Flores, 2007). During this time in the City of Vancouver, ten new venues for theatre, comedy, cinema, dance, and music were created, while five additional venues were extensively renovated and refurbished. These venues are the Stanley Industrial Alliance Stage, the Vancouver International Film Centre, the Fei and Milton Won Experimental Theatre, Pyatt Hall, the Orpheum Annex, The VanCity Culture Lab, 140 West $1^{\text {st }}$ Theatre, the 
Improv Centre, the PAL Theatre, the York Theatre, the Revue Stage renovation, The Cultch Historic Theatre renovation, the Vogue Theatre renovation, Queen Elizabeth Theatre renovation, and the Orpheum Theatre renovation.

This expansion of facilities coincided with a period of sustained growth in the overall employment of the city of Vancouver's cultural sector, which grew tremendously - a $23.7 \%$ increase since 1996 - and at a rate five times greater than general employment (City of Vancouver, 2008). The City of Vancouver now has the largest per-capita number of artists of any Canadian city and this concentration represents a globally-significant 'economic cluster' that has fostered the growth of related fields that include film and television production and post-production, computer-generated special effects, video game development, architecture and design, publishing, and lifestyle apparel design (Florida, 2012) (City of Vancouver, 2008).

At a national level, as of 2007 , approximately 670,000 people were employed directly by the arts and cultural sectors and this contributed $\$ 46$ billion to the national economy (McKinsley and Company, 2009). This impact increases to more than 1.1 million jobs and $\$ 84.7$ billion (7.4\% of GDP) of activity in the Canadian economy when the induced and indirect impacts of the arts and cultural sectors are calculated (Conference Board of Canada, 2008). This includes more than $\$ 5$ billion in cultural exports, such as Cirque Du Soleil (Conference Board of Canada, 2008). The arts and cultural sectors also induce philanthropy and volunteerism. Canadians donated \$188 million to arts and cultural organisations in 2004, while Statistics Canada determined that volunteers - who contribute an average of 120 hours a year - donated the equivalent of $\$ 3.2$ billion of their time in the year 2000 (Conference Board of Canada, 2008).

At the local level, more than three million people a year attend the more than 2,400 performing arts shows, festivals, and special cultural events held in the City of Vancouver; an attendance that eclipses even professional sport (City of Vancouver, 2008). The direct ticket revenue, theatre rents, and salaries to performers, technicians, and staff all amount to a substantial direct benefit to the local economy, while a steady stream of induced benefits also flow as 
event patrons take taxis, transit, or park, eat at restaurants, and even buy homes and start businesses in interesting and artistic neighbourhoods (McKinsley and Company, 2009).

As Vancouver continues to transition away from primary industry to a post-industrial knowledge and serviced-based economy fostering and maintaining a high quality of life and amenities becomes increasingly important. Richard Florida has written extensively about how global competition in the knowledge economy is now focused on mega-regions instead of countries, and within these mega-regions cities are competing to attract and retain the 'creative class' (Florida, 2012). People who earn their living in fields that require advanced education, like finance and real estate, healthcare, and law, are considered 'creative professionals' in Florida's classification, and are the foundation of knowledge economies. A subgroup of 'super-creative' professionals include the problem-solving disciplines of design, research, and engineering, along with artists and those in the cultural sector. This core group of the creative class can have a proportionately greater impact on the fortunes of cities through the creation of ideas and the fostering of positive notoriety for the city being tolerant, cultural, and creative which, in turn, attracts more like-minded people in a self-reinforcing cycle (Florida, 2012). Vancouver is well positioned to compete for the 'creative class', and the performing arts community is an important part of the broader narrative of Vancouver emerging as a welcoming cosmopolitan city with a high quality of life (Mercer, 2012). 


\section{The Importance of incubator Performing Arts Venues}

The performing arts are an entirely talent-based sector, where little proprietary information exists and all progress stems from the creativity and collaboration of people working together and experimenting. Performing artists' work is presented primarily in permanent professionallyrun venues that are purpose-built or extensively renovated to become venues. While the City of Vancouver owns and runs several marquee performing arts venues through its Civic Theatres division, the majority of the city's performing arts venues are privately owned and run by nonprofit and for-profit organisations that vary in size, age, mandate, and artistic discipline. Some performing arts companies own their own venue and are able to produce work throughout the year on a schedule of their own creation. However, most companies, especially those that have recently formed, or have niche appeal, are in a position where they rent access to venues one production at a time.

The lack of proprietary information, low initial barriers to entry, and the inherent support for collaboration and innovation all result in a high rate of company formation and cooperation within the performing arts sector. It is a fluid environment where people within the community meet socially or professionally, pursue some form of creative partnership, and frequently decide to formalize the endeavour by creating a new company to produce a piece of work. Up until the point where capital is required to hire performers, start production, and secure a venue in which to produce the show, most creative partnerships require little investment and no fixed premises. Many new performing arts companies start this way and are financed out of pocket and on credit by their founders. Until the crucial first show has been successfully produced, the new company has no track record upon which to seek significant capital, either through government and foundation grants or direct private investment. For these new companies to be able to take root and grow they need access to small and very low cost incubator performing arts venues. 


\section{Facility Inventory}

Vancouver is fortunate to have thirty permanent indoor professional performing arts venues that can accommodate theatre, music, and dance. There are additional rehearsal spaces, galleries, and multi-use spaces in the city that can accommodate some types of performance, along with many restaurants, cafes, lounges, and night clubs that host live music performances, however these spaces have not been included either because their primary purpose is not as a dedicated performance venue or because they are operated exclusively as live music venues and are unsuitable for other art forms. The thirty primary professional performing arts venues come in an eclectic variety of sizes and shapes that range from small hole-in-the-wall theatres tucked behind restaurants and under churches, all the way up to a magnificently gilded heritage theatre and a coolly mid-century modern opera house. (See table 1, below, and Appendix A,

\section{Venue Inventory)}

\section{Table 1. Performing Arts Venue Inventory}

\begin{tabular}{|c|c|c|c|c|}
\hline Name & Type & Seats & Classification & Neighbourhood \\
\hline 140 West 1st Ave & Black box studio theatre & 250 & Medium & Mount Pleasant \\
\hline Carousel Studio Theatre & Black box studio theatre & 49 & Incubator & Fairview \\
\hline $\begin{array}{l}\text { Fei and Milton Wong } \\
\text { Experimental Theatre }\end{array}$ & Black box studio theatre & 440 & Large & Downtown \\
\hline Firehall Arts Centre & Black box studio theatre & 136 & Incubator & Downtown East Side \\
\hline Granville Island Stage & Proscenium Stage Theatre & 450 & Large & Fairview \\
\hline Havana Theatre & Black box studio theatre & 60 & Incubator & Grandview-Woodland \\
\hline Jericho Arts Centre & Black box studio theatre & 135 & Incubator & Point Grey \\
\hline Metro Theatre & Proscenium Stage Theatre & 285 & Medium & Marpole \\
\hline Norman Rothstein Theatre & Proscenium Stage Theatre & 318 & Medium & Oakridge \\
\hline Orpheum Annex & Black box studio theatre & 193 & Medium & Downtown \\
\hline Orpheum Theatre & Proscenium Stage Concert Hall & 2,672 & Large & Downtown \\
\hline Pacific Theatre & Black box studio theatre & 128 & Incubator & Fairview \\
\hline PAL Theatre & Black box studio theatre & 120 & Incubator & Coal Harbour \\
\hline Performance Works & Black box studio theatre & 150 & Medium & Fairview \\
\hline Queen Elizabeth Theatre & Proscenium Stage Theatre & 2,765 & Large & Downtown \\
\hline Revue Stage & Proscenium Stage Theatre & 198 & Medium & Fairview \\
\hline $\begin{array}{l}\text { Roundhouse Performance } \\
\text { Centre }\end{array}$ & Black box studio theatre & 170 & Medium & Downtown \\
\hline Scotiabank Dance Centre & Black box studio theatre & 154 & Medium & Downtown \\
\hline
\end{tabular}




\begin{tabular}{|c|c|c|c|c|}
\hline $\begin{array}{l}\text { Stanley Industrial Alliance } \\
\text { Stage }\end{array}$ & Proscenium Theatre & 650 & Large & Fairview \\
\hline Studio 1398 & Black box studio theatre & 96 & Incubator & Fairview \\
\hline Studio 16 & Black box studio theatre & 78 & Incubator & Fairview \\
\hline Studio 58 & Black box studio theatre & 100 & Incubator & Oakridge \\
\hline $\begin{array}{l}\text { The Centre in Vancouver for } \\
\text { Performing Arts }\end{array}$ & Proscenium Stage Theatre & 1,836 & Large & Downtown \\
\hline The Cultch Historic Theatre & Proscenium Stage Theatre & 195 & Medium & Grandview-Woodland \\
\hline $\begin{array}{l}\text { The Cultch VanCity Culture } \\
\text { Lab }\end{array}$ & Black box studio theatre & 74 & Incubator & Grandview-Woodland \\
\hline The Improv Centre & Proscenium Stage Theatre & 186 & Medium & Fairview \\
\hline The Vogue Theatre & Proscenium Stage Theatre & 1,114 & Large & Downtown \\
\hline Vancouver Playhouse & Proscenium Stage Theatre & 668 & Large & Downtown \\
\hline Waterfront Theatre & Proscenium Stage Theatre & 224 & Medium & Fairview \\
\hline York Theatre & Proscenium Stage Theatre & 350 & Medium & Grandview-Woodland \\
\hline
\end{tabular}

Of the city's thirty primary venues, eight may be considered 'large' with capacities greater than 440 seats and the ability to mount technically challenging productions like Broadway plays, orchestral concerts, opera, and the ballet. Twelve venues are considered 'medium' with capacities that range from 150 to 350 seats. Many of have 'proscenium' stages, which are permanent and elevated from the floor for better audience visibility, and they typically also have spaces beside, behind, and sometimes above the stage which are not visible to the audience and used to store sets, costumes, props, and generally facilitate the technical staging of the performance. These venues are the main stages used by the theatre community and they combine a high degree of technical capacity and a relatively large number of seats with the ability to operate the venues using a limited number of technical crew and customer service staff. This balances revenue generating capacity against operating costs while still retaining the ability to mount most types of productions. A further ten small venues are considered 'incubators' with capacities that range from 49 to 136 seats. These highly flexible spaces are typically 'black box' studio theatres, which are defined by the absence of a permanent stage, a limited number of portable seats that may be configured differently from one production to the next, and a rudimentary lighting and sound equipment that can be run by a handful of crew. 


\section{Access to Venues}

In addition to size, the availability of venues in Vancouver can pose a challenge for new performing arts companies. Of the ten small incubator performing arts venues, four are affiliated or owned by arts organisations that produce an annual season of their own productions, which limits when the venues is available for rent. One venue is part of a postsecondary institution and is unavailable for rent. An additional two venues have limitations: one is available for rent for only part of the year and it primarily hosts youth-friendly shows; the other only presents works in French (Centre Culturel Francophonie de Vancouver, 2013) (Carousel Theatre for Young People, 2012). As a result of these constraints, in the City of Vancouver, there are only three permanent professional multi-disciplinary incubator performing arts venues - Havana Theatre, Studio 1398, and the PAL Theatre - that are available to rent throughout the year without the presence of a programmed season or constraints on programming. Finding a way to expand the number of small, available, and affordable incubator performing arts venues is a main priority of the Culture Plan for Vancouver and addressing this gap in the continuum of venues is an important to the health and sustained growth of the local arts and cultural sector. 


\section{Location of Venues}

While the characteristics of venues vary, their location within the city is fairly uniform. Twentytwo out of thirty venues are located in the three neighbourhoods (Downtown, Fairview, and Mount Pleasant) that make up the Metropolitan Core of the city; leaving only eight venues spread out among for the city's remaining eighteen neighbourhoods. (See Figure 1, Map of

\section{Performing Arts Venues in the City of Vancouver, on the following page)}

Figure 1. Map of Performing Arts Venues in the City of Vancouver

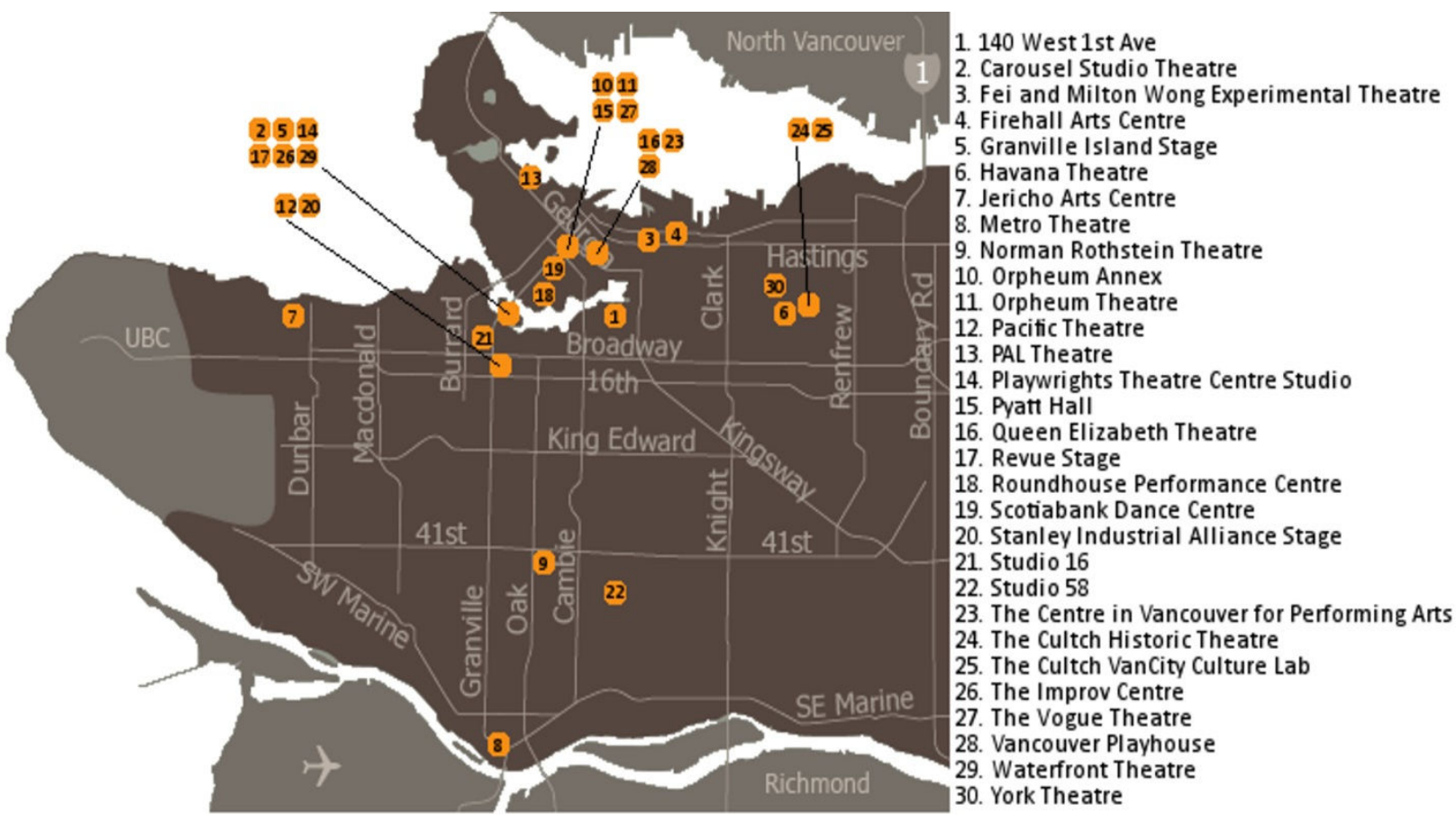

There are benefits to this concentration of venues, especially for businesses that are located close enough to benefit from regular patronage by audiences before and after they attend their performances. In this respect, the venue essentially acts as an 'anchor tenant' for the neighbourhood's commercial district. However, the concentration of venues also forfeits the opportunity to enliven commercial areas in other parts the city, some of which have no neighbourhood live entertainment options. It is good urban planning and a longstanding Council goal to foster 'complete' neighbourhoods in which residents have sufficient choice among commercial services, public amenities, and entertainment options near their homes to 
be able to choose to not travel elsewhere in the city. This fosters a sense of community and reduces vehicle travel in the city while simultaneously strengthening local neighbourhood economies. 


\section{Review of Growth Financing Tools - Development Cost Levies}

The Financing Growth development policy framework operates on the principle that growth should pay for itself and that public benefits will flow from the redevelopment of the city (City of Vancouver, 2011) (Punter, 2003). When a new development is proposed there is an expectation that the costs the City will incur - staff time for inspections and permit approvals, as well as the civil engineering to connect the new building to municipal water and sewage should be borne by the project proponent. These costs are recovered using Development Cost Levies (DCLs) and they have been in effect since 1990 and underwent substantial update in 2003 and 2012 (Punter, 2003) (City of Vancouver, 2012). In addition, the marginal cost associated with the new development for the capital-intensive facilities that the City provides to its citizens are factored into the DCL. These include levies for park land acquisition and improvements, affordable housing for those in core housing need, childcare facilities, and certain blended public realm/transportation facilities like neighbourhood greenways and streetscape improvements (City of Vancouver, 2009).

The revenue that is raised through DCLs, excluding the portion intended for immediate use on project staff and civil engineering costs, is allocated to a series of dedicated accounts for parks, affordable housing, childcare, and transportation. All development projects are assessed areaspecific, city-wide, or layered DCLs on a per-square-foot basis and these correspond to the amount of money that will be allocated to projects within the same geographic area and to those located elsewhere that service the city as a whole (City of Vancouver, 2004). A key rule of the $\mathrm{DCL}$ system is that none of the revenue may be allocated to general revenue. This is required by the Vancouver Charter, under which the City of Vancouver is incorporated, and it requires that all of it the $D C L$ is allocated to the accounts or active projects for which the fees were levied (City of Vancouver, 2009). DCLs supply a steady trickle of revenue that accrue until enough has been collected to build the project or facility for which it was intended. The City's Capital Plan process takes the amount of money that has been collected through DCLs throughout the city into account when decisions are made about borrowing. Debt-financing may be used to secure the capital that is required to accelerate a specific project or 
improvement, especially if its importance has increased due to changes in the neighbourhood context (City of Vancouver, 2009). While DCLs are a reliable source of funds for important 'must-haves' for the city, the high quality of life and ample 'nice-to-have' public amenities that are increasingly expected by citizens cannot be provided exclusively through this means or via the City's Capital Plan. 


\section{Review of Growth Financing Tools - Community Amenity Contributions}

As of right, the owner of a property is entitled to build and operate a building that is in compliance with the zoning and only pay DCLs. If they wish to pursue a form of development on their property that is not in compliance with the prevailing zoning, they must seek the assent of Council to approve a change in zoning; a process known as a rezoning (Punter, 2003). In 1989, Council approved a new form of land value capture called a Community Amenity Contribution (Punter, 2003). Community Amenity Contributions (CACs) were introduced in an effort to begin to broadly apply a philosophical principle that the Public should have a direct benefit from the increase in land value that is created by Public Officials' decision to rezone a property to a higher and better use (Punter, 2003). The increase in land value is called 'land lift' or the 'unearned increment'. Until the introduction of CACs, the benefits of the land lift had solely resided with the property owner.

Land lift occurs because a change in a property's zoning conveys additional rights and privileges (Slack, 2009). Only Council can change a property's zoning and it is City of Vancouver policy that the public, on whose behalf and best interest Council acts, should receive the majority of the benefit from a rezoning. The City aims to receive on behalf of its citizens approximately $85 \%$ of the land lift and use this money to build growth-supporting public amenities in the neighbourhood where the development occurs (City of Vancouver, 2011). The CAC is the dollar amount that is owed due to the land lift of a rezoning and this is determined through a rigorous pro-forma analysis by City staff and the applicant (City of Vancouver, 2011).

Once the dollar amount is agreed upon, City staff and the applicant negotiate how the CAC will be converted into public benefits to be delivered in-kind within the development project, or as cash-in-lieu to be used off-site but in the neighbourhood (City of Vancouver, 2011). CACs are primarily intended to cover the capital costs, but when appropriate they may also cover operating expenses via endowment funds (Punter, 2003). The City maintains guidelines for its Staff to follow when determining the type of amenity that should be pursued in negotiation with the project applicant. The CAC should be: 
1. Located in the community in which the rezoning takes place and/or serve the site;

2. Growth-related, or meet past deficiencies or other community priorities;

3. Operationally viable - i.e. long-term operating and maintenance costs are supportable;

4. Within City servicing standards - i.e. a type of service normally provided or supported by the City and at a service level supported by City policy;

5. Identified through an assessment of:

(a) the full range of City services and the adequacy of existing City amenities in the area;

(b) opportunities to meet needs;

(c) City plans and policies;

(d) the cost to provide the amenities;

(e) community input obtained during the rezoning and through community plans or Visions, and/or city-wide plans and policies; and,

(f) for negotiated rezonings, the development economics of the donor project.

(City of Vancouver, 2011)

This system is highly discretionary and if what the property owner proposes is not in compliance with the local area plan, neighbourhood plan, or Official Development Plan, the City may still allow a 'spot rezoning.' However, the project must earn its rezoning by demonstrating the application of City policy, good urban design and architecture, and a willingness to make every effort to incorporate needed public amenities through in-kind CACs that place the amenity on-site (Sandercock, 2006) (Punter, 2003). There may be compelling policy reasons for staff to support the rezoning proposal of a building that is out of scale with its neighbours. The immediate predecessor to the current Greenest City policy was the EcoDensity Charter. It calls for new growth to "achieve greater densities smartly and strategically in land-use patterns, locations and designs where carbon footprint improvements and environmental gains are highest" and Staff may use this as their policy rationale for recommending that Council approve a proposal that land significant density at site in a bustling neighbourhood that will be served by rapid transit in the relatively near future (City of Vancouver, 2008). 


\section{Proposal - Precedent for Incubator Neighbourhood Performing Arts Venues}

The local precedent for the following proposed concept of incubator neighbourhood performing arts venues is based a review of the current inventory of incubator performing arts venues. (See Table 2, below, and Appendix A. Venue Inventory)

Table 2. Incubator Performing Arts Venues.

\begin{tabular}{|l|l|l|l|l|}
\hline Name & Type & Seats & New/renovation & Neighbourhood \\
\hline Carousel Studio Theatre & Black box studio theatre & 49 & Renovation & Fairview \\
\hline Firehall Arts Centre & Black box studio theatre & 136 & Renovation & Downtown East Side \\
\hline Havana Theatre & Black box studio theatre & 60 & Renovation & Grandview-Woodland \\
\hline Jericho Arts Centre & Black box studio theatre & 135 & Renovation & Point Grey \\
\hline Pacific Theatre & Black box studio theatre & 128 & Renovation & Fairview \\
\hline PAL Theatre & Black box studio theatre & 120 & Incubator & Coal Harbour \\
\hline Studio 1398 & Black box studio theatre & 96 & Incubator & Fairview \\
\hline Studio 16 & Black box studio theatre & 78 & Incubator & Fairview \\
\hline Studio 58 & Black box studio theatre & 100 & Incubator & Oakridge \\
\hline The VanCity Culture Lab & Black box studio theatre & 74 & Incubator & Grandview-Woodland \\
\hline
\end{tabular}

These incubator venues share the common characteristic of being black box studio theatres. Their small size of 135 seats or less allows for inexpensive operation by a small running crew. The limited number of seats - and, thus, revenue generating capacity - also translates into an inexpensive venue to rent. Half of the venues are housed in buildings that were purpose-built to include the performing arts venue, while the other half is housed in buildings that were renovated to accommodate the cultural facilities. Most of the venues are located within a short distance of such a street, but only Havana Theatre is located directly on a main street in a mixed-use commercial area and it serves as an 'anchor tenant' for its portion of the commercial district. Havana Theatre is also the only venue that is not operated by a non-profit organisation or an institution, and its co-location with a retail business - a restaurant - helps to underwrite its operating costs and insulate it from the need to receive a cultural grant subsidy. It is upon Havana Theatre's operating model that the following proposal for incubator neighbourhood performing arts venues is based. 


\section{Proposal - The Havana Theatre Model}

Havana Theatre is an award-winning 60-seat performing arts venue located on Commercial Drive in the Grandview-Woodlands neighbourhood of Vancouver. The theatre is located inside Havana Restaurant in a mixed-use space that combines a lively Latin restaurant with an outdoor patio overlooking Grandview Park, and a gallery space for showcasing local talent that also functions as a lobby for theatre patrons. The black box studio theatre space has three levels of seating on risers and the performers use the floor as the stage.

The theatre and restaurant opened in 1996, and the theatre space was a part of the building renovation (Havana Restaurant, 2013). The financial viability of Havana Theatre is directly tied to its intentional sharing of space and operational costs with the restaurant portion of the business. This allows the theatre to be located on an expensive commercial street in a highly visible and accessible location without having to bear the cost of this location wholly through ticket receipts and venue rental fees. Furthermore, theatre patrons often choose to have a drink and a meal before the play and by eating in the restaurant they avoid the anxiety of missing the start of the show. Afterwards, some patrons may remain for a late meal or a drink. The theatre functions as an incubator performing arts venue due to its small size, very low rental fees, and simple operational requirements regarding staff and technicians. 


\section{Proposal - Core Assumption}

The following proposal is predicated upon the need for additional incubator performing arts venues. The Culture Plan identified that such a need exists and included the amelioration of the shortage of small venues in the Phase 1 2008-2023 Cultural Facilities Priorities Plan (City of Vancouver, 2008). However, there is risk that since the Culture Plan and the Cultural Facilities Priorities Plan were approved in 2008 the demand for additional venues has waned due to a combination of some or all of the following factors:

(1) schedule maximization of existing rental venues creating more 'room' for productions in the existing inventory;

(2) shorter runs (fewer performances) for productions creates more 'room' for productions in the existing inventory;

(3) additional rental capacity has been created through the renovation or construction of venues since 2008, specifically the renovation of the Revue Stage and the construction of the Improv Centre, Fei and Milton Wong Experimental Theatre, Pyatt Hall, The VanCity Culture Lab, and the Orpheum Annex;

(4) contraction of the performing arts sector due to cuts to Provincial and Federal cultural grants and declining philanthropy due to the 2008 'Great Recession' economic crisis; and

(5) contraction of the performing arts audience due to changing audience tastes and greater competition from other forms of entertainment and recreation.

In light of these changes Cultural Services staff should update the Culture Plan research data to confirm that demand remains for additional small performance venues. 


\section{Proposal - Core Principles}

If demand is proven, it is the recommendation of this report that Council adopt as Policy an implementation plan that creates incubator neighbourhood performing arts venues based the Havana Theatre model using the following principles:

i. Simple 'black box' performing arts venues with a capacity of 140 seats or less.

ii. A streamlined facility rental process and commitment to minimize rental fees.

iii. Each neighbourhood in the city will eventually receive a venue.

iv. Community Amenity Contributions (CACs) will be used to secure capital.

v. In the Central Area, in-kind CACs will be used to deliver venues on-site.

vi. Outside of the Central Area, accrued cash-in-lieu CACs will be used to deliver venues following a renovation-first approach that prioritizes the purchase and conversion of suitable buildings that would also have space for compatible revenue-generating commercial leases.

vii. The City of Vancouver Real Estate Division, operating on behalf of the Property Endowment Fund, would coordinate its investments with Cultural Services and the Planning Department to ensure that strategic buildings in a neighbourhood that would be suitable for later conversion to incubator performing arts venues would be optioned or purchased to protect them from redevelopment until sufficient CAC money has been accrued.

viii. Venues will be universally-accessible, energy efficient, and located on transit routes within established neighbourhood commercial areas.

ix. The City will retain ownership while competitively-chosen non-profit groups will operate the venues and associated businesses. 


\section{Proposal - Details}

\section{Inexpensive and Adaptable}

The purpose of incubator performing arts venues is that they are the first step of the venue ladder and they must be inexpensive to rent and simple to operate. For this reason, the new venues should be of a 'black box' theatre design, which has no permanent stage or fixed seating, limited lighting and sound equipment, and only essential backstage space for dressing rooms, costumes and props. In order to keep these venues small in physical size and manageable to operate by a small crew, the venues should have with a capacity of approximately 140 seats or less. Black box studio theatres are highly adaptable for different mediums of performing art and the lack of fixed seating and stage allow the space to be configured in a variety of ways that are impossible in a more conventional theatre or concert hall.

\section{Operationally Streamlined}

To help keep the cost of renting a venue as low and accessible as possible, it will be important to utilize a simple online venue booking system that incorporates all of the new City-created incubator neighbourhood performing arts venues. In the same way one searches online for flights and hotel options that match up with one's budget and time constraints, this online venue booking tool will allow performing arts companies to search for an available space during the span of time they wish to mount a production, input their venue technical requirements and preferred seating capacity, as well as their choice of neighbourhoods and then book the venue. This online venue booking tool would also be a smartphone app, which would allow for a producer to search, reserve, place a deposit, and sign off on the legal contract, all from one's smartphone or tablet.

\section{Geographically Equitable}

The City would commit that each neighbourhood in the city would eventually receive a venue by 2023: the end date for Phase 12008 - 2023 Cultural Facilities Priorities Plan. This equity is important because the current concentration of venues within a small number of venues 
precludes residents in much of the city from being able to enjoy live entertainment close to home. For neighbourhoods that are unlikely to receive new development, or are receiving ground-oriented infill development, such as detached single family homes, duplexes, and feesimple row houses, which are excluded from the CAC system, the City could chose to include incubator neighbourhood performing arts venues in its Capital Plan (City of Vancouver, 2004). While the potential exists for the Development Cost Levy system to be amended to include exactions for area-specific and city-wide cultural amenities, this is not recommended as part of this report.

\section{Growth-Driven}

The new incubator neighbourhood performing arts venues would be funded by capital secured by Community Amenity Contributions. This ties the creation of new amenities to the pace of growth in a neighbourhood and builds on existing precedent of examining existing amenity gaps when considering how a CAC will be allocated. Based on the one million dollar renovation budget required to create the 186-seat Improv Centre on Granville Island through an extensive renovation of an existing industrial building, it can be reasonably expected that the cost of creating incubator neighbourhood performing arts venues would be comparable or less (VanCity, 2010). Even with a \$1 million budget ceiling for the creation of a new facility, this is still within easy reach of the CACs that are produced by typical projects in the City of Vancouver (City of Vancouver, 2012).

\section{Purpose-built Venues Downtown}

In downtown Vancouver, the CACs that are generated through the rezoning of a typical tower and podium building are sufficient to cover the cost of creating an incubator neighbourhood performing arts venue through the renovation of an existing building (City of Vancouver, 2012). However, the property values and the scarcity of available developable lots downtown make the renovation of existing buildings into cultural facilities very unlikely. What has been achieved on numerous occasions, including the PAL Theatre, Pyatt Hall, and the Orphem Annex, is the incorporation of a CAC-funded cultural facility into a new building. When the CAC is allocated to 
the project from which it was generated, it is considered an in-kind contribution; meaning that the developer is using the CAC money to build the facility rather than transferring it to the City.

The advantage of this approach is that the developer can have their architects and engineers include the design of the cultural facility into the overall building project, thus saving the City the cost of hiring consultants and, thus, allowing more of the CAC to go towards the physical construction and fit-out of the space. Furthermore, the developer already owns the property in which the CAC-funded amenity will be built, and this saves the City the cost of purchasing a property in which to house the facility, or incur an opportunity cost of accommodating the amenity in a City-owned building instead of a rent-paying commercial tenant.

Finally, the developer may enthusiastically support the inclusion of the cultural facility in their building because it affords an opportunity to brand the building and differentiate it from others on the market. This was the case with Amacon's Brava towers in downtown Vancouver, which house the Vancouver International Film Centre and the offices of the Vancouver International Film Festival; both were created using a large CAC generated from permitting the property to be rezoned to a size and density that were sufficient to finance the new cultural facilities (Punter, 2003).

\section{Renovation-First Approach Outside of Downtown}

Outside of the Central Area, accrued cash-in-lieu CACs will be used to deliver venues following a renovation-first approach. This would prioritize the purchase and conversion of suitable existing buildings over efforts to incorporate the cultural facility into a new development. This approach allows for the incubator neighbourhood performing arts venue to be added into the existing fine-grain urban fabric of the neighbourhood without requiring the redevelopment of the subject property. In neighbourhoods where there is resistance to change and redevelopment, the preservation of the existing urban fabric at the heart of the neighbourhood, while simultaneously adding vitality and cultural activity to the area, is likely to gain resident support and more directly connect the principles of positive change flowing from development. 
A thorough study of current zoning, local area plans, community plans, and official community development plans for the city's neighbourhoods finds that much of the new development that is expected to occur in the near future will be of the mid-rise built form (City of Vancouver, 2013). The success and support for this type of built-form is highly dependent on its urban design, specifically setbacks and height that is proportional to the street. To date, there is no experience with incorporating performing arts venues in this type of building, where sound and vibration can easily carry through the wood frame structure.

Finally, for future projects that will be of significant enough size to be able to generate CACs through their rezoning that could create incubator neighbourhood performing arts venues inkind and on-site, there are other pressing public benefits that are also expected to be created as a result of new growth. Daycares, affordable housing, and public parks and green space are likely to be considered more appropriate candidate amenities when determining how the CACs for a large project will be apportioned.

\section{Strategically Buy Properties}

The City of Vancouver Real Estate Division, operating on behalf of the Property Endowment Fund, would coordinate its investments with Cultural Services and the Planning Department to ensure that strategic buildings in a neighbourhood that would be suitable for later conversion to incubator performing arts venues would be optioned or purchased to protect them from redevelopment until sufficient CAC money has been accrued. In areas of the city where high rates of development and growth are occurring, only a relatively short period of time would be required to accrue sufficient CAC resources to buy a building and renovate it to house an incubator neighbourhood performing arts venue. For fast-growing neighbourhoods, the decision of whether to deploy Real Estate Division capital to secure a building would depend on the available stock of suitable properties and the rate at which property values were increasing. If there were a limited number of suitable candidate buildings, it would be prudent to utilize 
the Real Estate division to purchase the property and then reimburse the Property Endowment Fund using CAC money once the project was initiated. For slow-growing neighbourhoods, the Real Estate Division may still need to purchase a suitable candidate building in order to meet the proposed 10-year, 2023 deadline for completing the venues.

\section{Accessible and Efficient}

The new venues must be universally-accessible for audience members and performers. This includes level access to the building via the street entrance and fire exits, as well as being fully code-compliant for the venue's internal fit out and washrooms. The preferred location of the venues is on main neighborhood commercial streets where the sidewalks offer universal accessibility with curb let-downs and accessible intersections. Main streets also facilitate movement via public transit and the HandyDart para-transit service.

The venues should be designed to be energy efficient with an emphasis on silent mechanical systems for the performance area in the venue and places where noise could travel to the audience chamber. These facilities are an opportunity to put the Greenest City Action Plan into practice and simultaneously educate the public about the sustainability attributes of the space. If the incubator neighbourhood performing arts venue is built as part of a new development, it will have to contribute to the building achieving LEED (Leadership in Energy and Environmental Design) Gold certification, which is mandatory for all rezoned buildings as of January $1^{\text {st }}, 2012$ (City of Vancouver, 2013). For renovated buildings, achieving LEED Gold is not a requirement, but the core principles of aggressive energy and water conservation are to be followed. To date, only the only LEED-certified performing arts space in Vancouver is the renovated Cultch Historic Theatre, which attained the LEED Silver designation (The Vancouver East Cultural Centre, 2013). 


\section{Financially Sustainable Operation}

The City will retain ownership of the incubator neighbourhood performing arts venues, but they will be operated by competitively-chosen non-profit groups. Tenant calls will be issued for qualified operators to take on multi-year leases for venues and they will be responsible for every aspect of their operation while paying a nominal annual rent to the City.

It is difficult to operate a small venue at a profit, particularly when there is a mandate to have the venues serve as a cultural incubator. Many of Vancouver's venues - small and large include a revenue-generating bar or lounge to help subsidize the cost of operating the theatre, while two even operate full service restaurants. Each incubator neighbourhood performing arts venues will also include an attached commercial retail unit that will be a part of the venue lease. The tenant call will require respondents to present a viable business plan that includes the cost of fitting out and operating the retail component and it is likely that most proponents will propose a restaurant for this space. Operators would be allowed to run multiple incubator neighbourhood performing arts venues, provided that their business cases are sound and they successfully win the tenant call for each venue. Efficiencies from operating multiple venues would be considered in order to assure the greatest likelihood of success and to secure against business failures that would shutter a venue until a new operator could be chosen.

Large established arts organisations would also be eligible to bid on a venue and their experience and financial resources would be favourable attributes in the tenant call evaluation process. Joint-ventures between established arts organisations would also be allowed and such a scenario has occurred for the tenant call of the 140 West $1^{\text {st }}$ Avenue performing arts venue wherein the Arts Club Theatre Company, Pacific Theatre Company, and Bard on the Beach jointly applied to operate the new 44,000 square foot, 250-seat facility (Hoekstra, 2012). 


\section{Discussion - Opportunities and Risk}

The proposed model presents creates numerous opportunities and exposure to certain risks.

\section{Opportunities:}

- Employment in the performing arts sector will grow as more companies have the ability to simultaneously produce work for paying audiences.

- A significant increase in the performing arts presentation capacity in the city may induce a greater number of performances in annual and per capita measures.

- Businesses in the immediate vicinity of the new venues will benefit when audiences patronize restaurants, bars, and shops before or after a performance.

- The venues and their on-site businesses - likely restaurants or bars - may prove to be neighbourhood hot spots and have a positive 'halo' effect on other nearby businesses.

- The preservation of buildings through the renovation-first approach to venue creation outside of the Central Area secure pieces of each neighbourhood's built environment from redevelopment. The impact on the city's built history will be even greater if sufficient capital is deployed to save historic or architecturally significant buildings.

- Established theatre companies may bid to operate the incubator neighbourhood performing arts venues and offer apprenticeships to train the next generation of technical crews and staff.

- Complex and technically demanding shows that are artistically most appropriate in an intimate venue could be executed by venues that are run by established theatre companies, whose staff would have expertise with running such shows in their larger venues.

- A joint-institution practical learning model could be created to a venue that would be jointly run by Langara University College's Studio 58 theatre school and Vancouver Community College's culinary school and entrepreneurial business program. Studio 58 theatre students would continue their practice of producing and performing in shows directed by industry professionals, while also gaining the practical operational experience 
of operating the venue. The culinary students and entrepreneurial business students would run the business end of the venue as a restaurant or café.

Risk:

- The cost of purchasing a property and renovating the building to house the venue may require too great a proportion of a neighbourhood's CACs between the present and the 2023 end date for the Cultural Facilities Priorities Plan 2008-2023. When decisions are made between allocating CACs for the incubator neighbourhood performing arts venue or daycares, affordable housing, libraries, and other public amenities, the former may not be deemed to be a sufficient priority - especially if the neighbourhood is already home to performing arts venues.

- There may not be sufficient redevelopment activity and rezoning proposals for each neighbourhood to self-finance their own venue through CACs in slow-growing parts of the city or if the real estate sector slows and the pace of development declines. There may not be sufficient political or public support to add incubator neighbourhood performing arts venues to the City's Capital Plan and debt-financing schedule.

- Community resistance to the redevelopment of their neighbourhood may lead the City and project applicants to favour rezonings that strictly comply with a local area plan and the existing zoning by-laws, instead of spot-rezonings that involve the creation of a new CD-1 zoning by-law. This will forfeit sufficient CAC revenue to build the incubator neighbourhood performing arts venues on a rapid schedule since the land-lift would generally be lower on a project that was in compliance with existing zoning and local area plans.

- The business case for building incubator neighbourhood performing arts venues in each neighbourhood may not be supportable. Some parts of the city may not be able to support a restaurant or business that would be, in turn, able to support the operations of the venue.

- The for-profit business that should sustain the venue may fail for reasons including poor management, uncompetitive product or service, or failure to generate sufficient revenue 
to cover its own operations and meet its contractual obligations to operate the venue as per the tenant agreement with the City.

- Failed venues may require extensive renovations prior to a new operator being able to open for business and some venues may remain dormant for years before a new tenant call is successful.

- Inexperience with business planning may result in the successful bidder of a venue being unable to complete the necessary renovations that will permit them to open and operate. If opening is possible, the operator may not be able to execute their business plan and create a going concern.

- The simultaneous operation of a performing arts venue and a restaurant or bar in the same premises may prove to be incompatible. Significant sound insulation will be required, along with physical separation of inner and outer walls to minimize vibrations and sound transfer. Even so, the artistic quality and audience enjoyment of works presented in these venues may be comprised to the point of avoidance on the part of performers and audiences alike.

- Ownership quarrels between business partners may result in the business declining and affecting the ability for it to continue as a going concern. The ability to sell the business would also need to be determined so that the operators with whom the City signed the lease and operating contract are the same as those who actually operate it.

To address many of the risks, careful scrutiny on the part of the City during the tenant call and bidder selection process will be essential for the proposed model to be successful. The City's Solicitor and legal department will need to draft careful contracts and operating agreements and determine through what mechanisms enforcement will be pursued if an operator fails to live up to the agreement. The length of the contract will also need to be balanced against the capital that the proponent will require to renovate the business component of the venue facility and launch the business. If the estimated return on investment with industry-standard margins is longer than the contract period, the response to tenant calls will be poor and the quality of the bidders will reflect the absence of experienced restaurateurs and business 
operators. A further consideration is whether the City would collect rent on a cost-recovery or profit-generating model, and whether it would assess property taxes. All of these considerations will need to be addressed by Staff working groups as they prepare the implementation plan. While the model was successful for Havana Theatre, it is possible that a unusually loyal customer base and the drawing power of Havana Restaurant's location on Commercial Drive may be ' $X$ factors' that incubator neighbourhood performing arts venues elsewhere in the city may lack. 


\section{Discussion - Financial Implications}

The City's financial exposure and investment will vary from one venue to the next. In an area with a high rate of redevelopment and steady CAC revenue stream, it is likely that the City will not be required to deploy any non-CAC capital. In areas with slow rates of development the City may be required to utilize the resources of its Real Estate department to purchase a property for the venue and deploy capital from the Capital Plan in order to meet the Cultural Facilities Priorities Plan 2008-2023 end date. An alternative is to accept that the venues will be built out as fast as CAC revenue will allow and not commit to meeting the 2023 end date of the Plan.

CAC revenue would also be used to renovate the purchased buildings in order to create the incubator neighbourhood performing arts venue. The venue would be fully fitted out using CAC money so that it would be ready to commence operations as soon as renovations were complete. The commercial retail space that would accompany the venue would be roughed in, with all the necessary electrical, plumbing, air handling, and mechanical connections, but it would be up to the successful bidder of the tenant call to complete the space to the specifications of their business plan. Neither CAC nor City resources would not be utilized for the fit-out and construction of this portion of the project.

There would be no financial implications for the City with regards to the operation of the incubator neighbourhood performing art venues. The operator would be responsible for all utility and business costs, including staff wages and benefits, payroll and business taxes, and WorkSafe BC premiums. The operator would also be responsible for ensuring that their business and the venue meet or exceed all applicable codes and by-laws, and it would be responsible for insuring the business, including potential payments to the City to cover the marginal cost of the municipality's policy on sites it owns. It is possible that an established nonprofit arts group that successfully won a bid on the tenant call of a venue could also receive City cultural grants to support its work, but the grant could not be used to fund the operating cost of the venue. Furthermore, it is possible that City cultural grants may be received by a performing arts company that presents work at an incubator neighbourhood performing arts 
venue, but this would not construe a subsidy of the operation of the venue. If a building were chosen to house the venue and its commercial retail unit and it also had additional leasable space, the revenue that would be generated would flow to the City's Real Estate division and the Property Endowment Fund. 


\section{Discussion - Implementation}

The proposed plan for creating incubator neighbourhood performing arts venues can be implemented immediately. Staff in the Planning Department's Rezoning Centre would have the ability to begin negotiating in-kind CACs that would be used to build on-site incubator neighbourhood performing arts venues in the Central Area and cash-in-lieu CACs to be used under the renovation-first approach to creating venues in the rest of the City. The City's Real Estate Department would begin identifying candidate buildings that met the requirements of incubator neighbourhood performing arts venues, including:

- Street-level presence on a main street in a neighbourhood's established commercial area.

- High ceilings and good structure that will allow for the construction of an audience chamber for the venue with sufficient clearance for a grid to be hung from the ceiling for lighting and sound equipment and commercial kitchen loads.

- Floors with sufficient dead load capacity to support audience seating and the weight loads associated with production equipment.

- Capacity to use or create a commercial retail unit on-site that would subsidize the operations of the venue.

- Emergency exit capacity and egress routes to accommodate the expected occupant load of venue patrons and business patrons.

- Preferably a building with some street presence due to its location, architectural character, or community significance.

- Adjacent restaurants and retail businesses.

- No residential uses on-site. Additional commercial uses are acceptable, including retail and office, but compatibility with the venue will take precedence.

- Level access and the ability to make the facility universally accessible. 


\section{Conclusion}

The Culture Plan for Vancouver is the current framework for Council to support the city's arts and cultural sectors. It reaffirms support for the cultural sector and commits the city to the continued deployment of targeted funding and programming and nuanced policy-making. The Plan acknowledges that access to small performance spaces is a priority for the performing arts community and Council has taken steps to ease the process of City approval for unconventional cultural spaces (Cole, 2013). The Culture Plan, and its Phase 1 Cultural Facilities Priorities Plan support the creation of new and renovated incubator neighbourhood performing arts venues and recognize that these are vital components of a healthy and growing cultural sector in the City of Vancouver. These new venues can be created throughout the city using existing growth financing tools in order to ease the shortage of small performance venues and support the performing arts community, while further establishing Vancouver as a city of culture.

Due to the small physical size and limited technical requirements of black box theatres, they are the ideal format for creating new incubator neighbourhood performing arts venues. In the neighbourhoods of downtown Vancouver, these new venues would be created through the use of in-kind CACs and be built on-site in new developments. Outside of downtown they would be created primarily through the renovation of existing buildings. This will allow the venues to be located right in the heart of the neighbourhood without the alteration of the established finegrain built fabric of the street.

The fundamental vision of incubator neighbourhood performing arts venues is a constellation of local, low-cost cultural hubs throughout the city. They will be cozy, familiar places for residents of the immediate neighbourhood, who would take pride and feel a sense of ownership. For residents living elsewhere in the city, they will be quirky and exciting destinations that prompt a visit from time to time. Most importantly, the incubator neighbourhood performing arts venues will help new performing arts companies get a foothold and thrive and, in time, help create new culturally-significant works. 


\section{APPENDIX A. VENUE INVENTORY}

Table 3. Venue Inventory

\begin{tabular}{|c|c|c|c|c|c|c|}
\hline Name & Venue Type & Seats & Neighbourhood & Operator & $\begin{array}{l}\text { New vs } \\
\text { Renovation }\end{array}$ & Source \\
\hline 140 West $1^{\text {st }}$ & $\begin{array}{l}\text { Black box } \\
\text { studio } \\
\text { theatre }\end{array}$ & 250 & Mount Pleasant & $\begin{array}{l}\text { City of Vancouver } \\
\text { (Formerly) } \\
\text { Vancouver } \\
\text { Playhouse } \\
\text { Theatre Company }\end{array}$ & New & $\begin{array}{l}\text { (City of } \\
\text { Vancouver, } \\
\text { 2012) }\end{array}$ \\
\hline $\begin{array}{l}\text { Carousel Studio } \\
\text { Theatre }\end{array}$ & $\begin{array}{l}\text { Black box } \\
\text { studio } \\
\text { theatre }\end{array}$ & 49 & Fairview & $\begin{array}{l}\text { Carousel Theatre } \\
\text { for Young People }\end{array}$ & Renovation & $\begin{array}{l}\text { (Carousel } \\
\text { Theatre for } \\
\text { Young People, } \\
\text { 2012) }\end{array}$ \\
\hline $\begin{array}{l}\text { Fei and Milton } \\
\text { Wong } \\
\text { Experimental } \\
\text { Theatre }\end{array}$ & $\begin{array}{l}\text { Black box } \\
\text { studio } \\
\text { theatre }\end{array}$ & 440 & Downtown & $\begin{array}{l}\text { Simon Fraser } \\
\text { University }\end{array}$ & New & $\begin{array}{l}\text { (Simon Fraser } \\
\text { University, } \\
\text { 2013) }\end{array}$ \\
\hline Firehall Arts Centre & $\begin{array}{l}\text { Black box } \\
\text { studio } \\
\text { theatre }\end{array}$ & 136 & $\begin{array}{l}\text { Downtown East } \\
\text { Side }\end{array}$ & $\begin{array}{l}\text { Firehall Arts } \\
\text { Centre }\end{array}$ & Renovation & $\begin{array}{l}\text { (Firehall Arts } \\
\text { Centre, 2013) }\end{array}$ \\
\hline $\begin{array}{l}\text { Granville Island } \\
\text { Stage }\end{array}$ & $\begin{array}{l}\text { Proscenium } \\
\text { stage theatre }\end{array}$ & 450 & Fairview & $\begin{array}{l}\text { Arts Club Theatre } \\
\text { Company }\end{array}$ & Renovation & $\begin{array}{l}\text { (Arts Club } \\
\text { Theatre } \\
\text { Company, } \\
\text { 2013) }\end{array}$ \\
\hline $\begin{array}{l}\text { Havana Theatre } \\
\text { and Gallery }\end{array}$ & $\begin{array}{l}\text { Black box } \\
\text { studio } \\
\text { theatre }\end{array}$ & 60 & $\begin{array}{l}\text { Grandview- } \\
\text { Woodland }\end{array}$ & $\begin{array}{l}\text { Havana } \\
\text { Restaurant }\end{array}$ & Renovation & $\begin{array}{l}\text { (Havana } \\
\text { Restaurant, } \\
\text { 2013) }\end{array}$ \\
\hline Jericho Arts Centre & $\begin{array}{l}\text { Black box } \\
\text { studio } \\
\text { theatre }\end{array}$ & 135 & Point Grey & $\begin{array}{l}\text { Jericho Arts } \\
\text { Centre Society }\end{array}$ & Renovation & $\begin{array}{l}\text { (Friends of } \\
\text { Jericho Arts } \\
\text { Centre Society } \\
\text {, No date) }\end{array}$ \\
\hline Metro Theatre & $\begin{array}{l}\text { Proscenium } \\
\text { stage theatre }\end{array}$ & 285 & Marpole & $\begin{array}{l}\text { Metro Theatre } \\
\text { Co-op }\end{array}$ & Renovation & $\begin{array}{l}\text { (Metro } \\
\text { Theatre } \\
\text { Vancouver, } \\
\text { 2013) }\end{array}$ \\
\hline $\begin{array}{l}\text { Norman Rothstein } \\
\text { Theatre }\end{array}$ & $\begin{array}{l}\text { Proscenium } \\
\text { stage theatre }\end{array}$ & 318 & Oakridge & $\begin{array}{l}\text { Jewish } \\
\text { Community } \\
\text { Centre of Greater } \\
\text { Vancouver }\end{array}$ & New & $\begin{array}{l}\text { (Jewish } \\
\text { Community } \\
\text { Centre of } \\
\text { Greater } \\
\text { Vancouver, } \\
\text { 2013) }\end{array}$ \\
\hline Orpheum Annex & $\begin{array}{l}\text { Black box } \\
\text { studio } \\
\text { theatre }\end{array}$ & 193 & Downtown & $\begin{array}{l}\text { The Vancouver } \\
\text { Symphony } \\
\text { Orchestra }\end{array}$ & New & $\begin{array}{l}\text { (City of } \\
\text { Vancouver, } \\
2012 \text { ) }\end{array}$ \\
\hline Orpheum Theatre & $\begin{array}{l}\text { Proscenium } \\
\text { stage concert } \\
\text { hall }\end{array}$ & 2,672 & Downtown & $\begin{array}{l}\text { Civic Theatres } \\
\text { (City of } \\
\text { Vancouver) }\end{array}$ & $\begin{array}{l}\text { New (with) } \\
\text { renovations }\end{array}$ & $\begin{array}{l}\text { (City of } \\
\text { Vancouver, } \\
2013 \text { ) }\end{array}$ \\
\hline
\end{tabular}




\begin{tabular}{|c|c|c|c|c|c|c|}
\hline Pacific Theatre & $\begin{array}{l}\text { Black box } \\
\text { studio } \\
\text { theatre }\end{array}$ & 128 & Fairview & Pacific Theatre & Renovation & $\begin{array}{l}\text { (Pacific } \\
\text { Theatre, 2013) }\end{array}$ \\
\hline PAL Theatre & $\begin{array}{l}\text { Black box } \\
\text { studio } \\
\text { theatre }\end{array}$ & 120 & Coal Harbour & $\begin{array}{l}\text { Performing Arts } \\
\text { Lodge }\end{array}$ & New & $\begin{array}{l}\text { (Performing } \\
\text { Arts Lodge } \\
\text { Society, 2010) }\end{array}$ \\
\hline $\begin{array}{l}\text { Performance } \\
\text { Works }\end{array}$ & $\begin{array}{l}\text { Black box } \\
\text { studio } \\
\text { theatre }\end{array}$ & 150 & Fairview & $\begin{array}{l}\text { Granville Island } \\
\text { Cultural Society }\end{array}$ & Renovation & $\begin{array}{l}\text { (Performance } \\
\text { Works, 2013) }\end{array}$ \\
\hline Pyatt Hall & Recital Hall & 120 & Downtown & $\begin{array}{l}\text { Vancouver } \\
\text { Symphony } \\
\text { Orchestra School } \\
\text { of Music }\end{array}$ & New & $\begin{array}{l}\text { (Vancouver } \\
\text { Symphony } \\
\text { School of } \\
\text { Music, 2013) }\end{array}$ \\
\hline $\begin{array}{l}\text { Queen Elizabeth } \\
\text { Theatre }\end{array}$ & $\begin{array}{l}\text { Proscenium } \\
\text { stage opera } \\
\text { house }\end{array}$ & 2,765 & Downtown & $\begin{array}{l}\text { Civic Theatres } \\
\text { (City of } \\
\text { Vancouver) }\end{array}$ & $\begin{array}{l}\text { New (with } \\
\text { renovations) }\end{array}$ & $\begin{array}{l}\text { (City of } \\
\text { Vancouver, } \\
\text { 2013) }\end{array}$ \\
\hline Revue Stage & $\begin{array}{l}\text { Proscenium } \\
\text { stage theatre }\end{array}$ & 198 & Fairview & $\begin{array}{l}\text { Arts Club Theatre } \\
\text { Company }\end{array}$ & Renovation & $\begin{array}{l}\text { (Arts Club } \\
\text { Theatre } \\
\text { Company, } \\
\text { 2013) }\end{array}$ \\
\hline $\begin{array}{l}\text { Roundhouse } \\
\text { Performance } \\
\text { Centre }\end{array}$ & $\begin{array}{l}\text { Black box } \\
\text { studio } \\
\text { theatre }\end{array}$ & 170 & Downtown & $\begin{array}{l}\text { Roundhouse } \\
\text { Community Arts } \\
\text { and Recreation } \\
\text { Centre }\end{array}$ & Renovation & $\begin{array}{l}\text { (Roundhouse } \\
\text { Community } \\
\text { Arts and } \\
\text { Recreation } \\
\text { Centre, 2013) }\end{array}$ \\
\hline $\begin{array}{l}\text { Scotiabank Dance } \\
\text { Centre }\end{array}$ & $\begin{array}{l}\text { Black box } \\
\text { dance studio }\end{array}$ & 154 & Downtown & The Dance Centre & New & $\begin{array}{l}\text { (Scotiabank } \\
\text { Dance Centre, } \\
\text { 2013) }\end{array}$ \\
\hline $\begin{array}{l}\text { Stanley Industrial } \\
\text { Alliance Stage }\end{array}$ & $\begin{array}{l}\text { Proscenium } \\
\text { stage theatre }\end{array}$ & 650 & Fairview & $\begin{array}{l}\text { Arts Club Theatre } \\
\text { Company }\end{array}$ & Renovation & $\begin{array}{l}\text { (Arts Club } \\
\text { Theatre } \\
\text { Company, } \\
\text { 2013) }\end{array}$ \\
\hline Studio 1398 & $\begin{array}{l}\text { Black box } \\
\text { studio } \\
\text { theatre }\end{array}$ & 96 & Fairview & $\begin{array}{l}\text { Playwrights } \\
\text { Theatre Centre }\end{array}$ & New & $\begin{array}{l}\text { (Granville } \\
\text { Island Cultural } \\
\text { Society, 2013) }\end{array}$ \\
\hline Studio 16 & $\begin{array}{l}\text { Black box } \\
\text { studio } \\
\text { theatre }\end{array}$ & 74 & Fairview & $\begin{array}{l}\text { Centre Culturel } \\
\text { Francophonie de } \\
\text { Vancouver }\end{array}$ & New & $\begin{array}{l}\text { (Centre } \\
\text { Culturel } \\
\text { Francophonie } \\
\text { de Vancouver, } \\
\text { 2013) }\end{array}$ \\
\hline Studio 58 & $\begin{array}{l}\text { Black box } \\
\text { studio } \\
\text { theatre }\end{array}$ & 120 & Oakridge & $\begin{array}{l}\text { Langara } \\
\text { University College }\end{array}$ & New & $\begin{array}{l}\text { (Langara } \\
\text { University } \\
\text { College, 2013) }\end{array}$ \\
\hline $\begin{array}{l}\text { The Centre in } \\
\text { Vancouver for } \\
\text { Performing Arts }\end{array}$ & $\begin{array}{l}\text { Proscenium } \\
\text { stage theatre }\end{array}$ & 1,836 & Downtown & $\begin{array}{l}\text { The Centre in } \\
\text { Vancouver for } \\
\text { Performing Arts }\end{array}$ & New & $\begin{array}{l}\text { (The Centre in } \\
\text { Vancouver for } \\
\text { Performing } \\
\text { Arts, 2007) }\end{array}$ \\
\hline
\end{tabular}




\begin{tabular}{|c|c|c|c|c|c|c|}
\hline $\begin{array}{l}\text { The Cultch Historic } \\
\text { Theatre }\end{array}$ & $\begin{array}{l}\text { Proscenium } \\
\text { Stage theatre }\end{array}$ & 195 & $\begin{array}{l}\text { Grandview- } \\
\text { Woodland }\end{array}$ & $\begin{array}{l}\text { The Vancouver } \\
\text { East Cultural } \\
\text { Centre }\end{array}$ & Renovation & $\begin{array}{l}\text { (The } \\
\text { Vancouver } \\
\text { East Cultural } \\
\text { Centre, 2013) }\end{array}$ \\
\hline $\begin{array}{l}\text { The VanCity } \\
\text { Culture Lab }\end{array}$ & $\begin{array}{l}\text { Black box } \\
\text { studio } \\
\text { theatre }\end{array}$ & 74 & $\begin{array}{l}\text { Grandview- } \\
\text { Woodland }\end{array}$ & $\begin{array}{l}\text { The Vancouver } \\
\text { East Cultural } \\
\text { Centre }\end{array}$ & New & $\begin{array}{l}\text { (The } \\
\text { Vancouver } \\
\text { East Cultural } \\
\text { Centre, 2013) }\end{array}$ \\
\hline The Improv Centre & $\begin{array}{l}\text { Proscenium } \\
\text { stage theatre }\end{array}$ & 186 & Granville Island & $\begin{array}{l}\text { Vancouver } \\
\text { Theatresports } \\
\text { League }\end{array}$ & Renovation & $\begin{array}{l}\text { (Vancouver } \\
\text { Theatresports } \\
\text { League, 2013) }\end{array}$ \\
\hline $\begin{array}{l}\text { The Vancouver } \\
\text { Playhouse }\end{array}$ & $\begin{array}{l}\text { Proscenium } \\
\text { stage theatre }\end{array}$ & 668 & Downtown & $\begin{array}{l}\text { Civic Theatres } \\
\text { (City of } \\
\text { Vancouver) }\end{array}$ & $\begin{array}{l}\text { New (with } \\
\text { renovations) }\end{array}$ & $\begin{array}{l}\text { (City of } \\
\text { Vancouver, } \\
\text { 2013) }\end{array}$ \\
\hline The Vogue Theatre & $\begin{array}{l}\text { Proscenium } \\
\text { stage concert } \\
\text { hall }\end{array}$ & 1,114 & Downtown & $\begin{array}{l}\text { The Vogue } \\
\text { Theatre }\end{array}$ & New & $\begin{array}{l}\text { (The Vogue } \\
\text { Theatre, 2010) }\end{array}$ \\
\hline Waterfront Theatre & $\begin{array}{l}\text { Proscenium } \\
\text { stage theatre }\end{array}$ & 224 & Fairview & $\begin{array}{l}\text { Granville Island } \\
\text { Cultural Society }\end{array}$ & Renovation & $\begin{array}{l}\text { (Granville } \\
\text { Island Cultural } \\
\text { Society, No } \\
\text { date) }\end{array}$ \\
\hline York Theatre & $\begin{array}{l}\text { Proscenium } \\
\text { stage theatre }\end{array}$ & 350 & $\begin{array}{l}\text { Grandview- } \\
\text { Woodlands }\end{array}$ & $\begin{array}{l}\text { Vancouver East } \\
\text { Cultural Centre }\end{array}$ & Renovation & $\begin{array}{l}\text { (The } \\
\text { Vancouver } \\
\text { East Cultural } \\
\text { Centre, 2013) }\end{array}$ \\
\hline
\end{tabular}


140 West $1^{\text {st }}$ Avenue Theatre

\begin{tabular}{|c|c|c|c|c|c|c|}
\hline Name & Type & Size & Location & Operator & $\begin{array}{l}\text { New vs } \\
\text { Renovation }\end{array}$ & Source \\
\hline $\begin{array}{l}140 \text { West } 1^{\text {st }} \\
\text { Avenue }\end{array}$ & $\begin{array}{l}\text { Black box } \\
\text { studio } \\
\text { theatre }\end{array}$ & 250 & $\begin{array}{l}\text { Mount } \\
\text { Pleasant }\end{array}$ & $\begin{array}{l}\text { City of } \\
\text { Vancouver }\end{array}$ & New & $\begin{array}{l}\text { (City of } \\
\text { Vancouver, 2012) }\end{array}$ \\
\hline
\end{tabular}

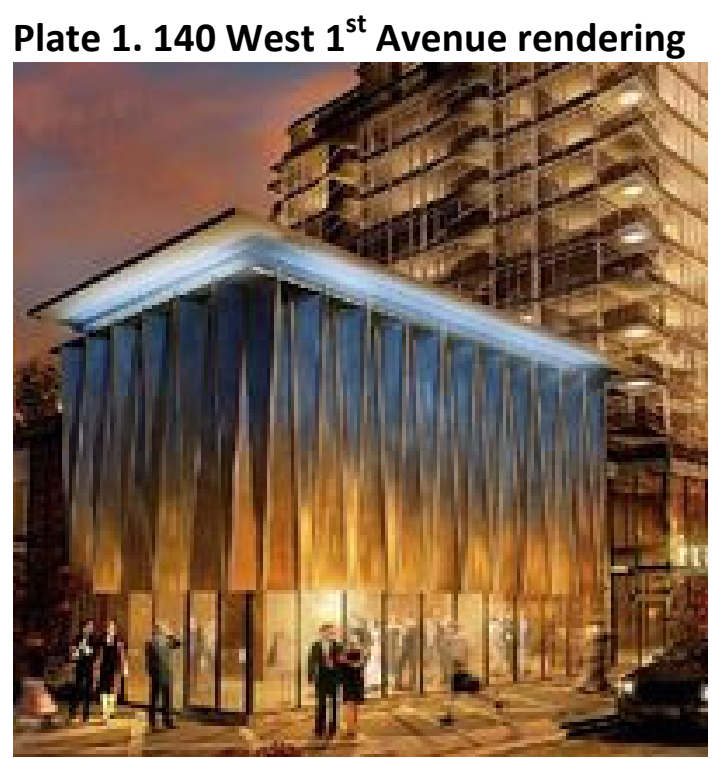

(Wall Financial Corporation, No date)
Plate 2. 140 West $1^{\text {st }}$ Avenue construction

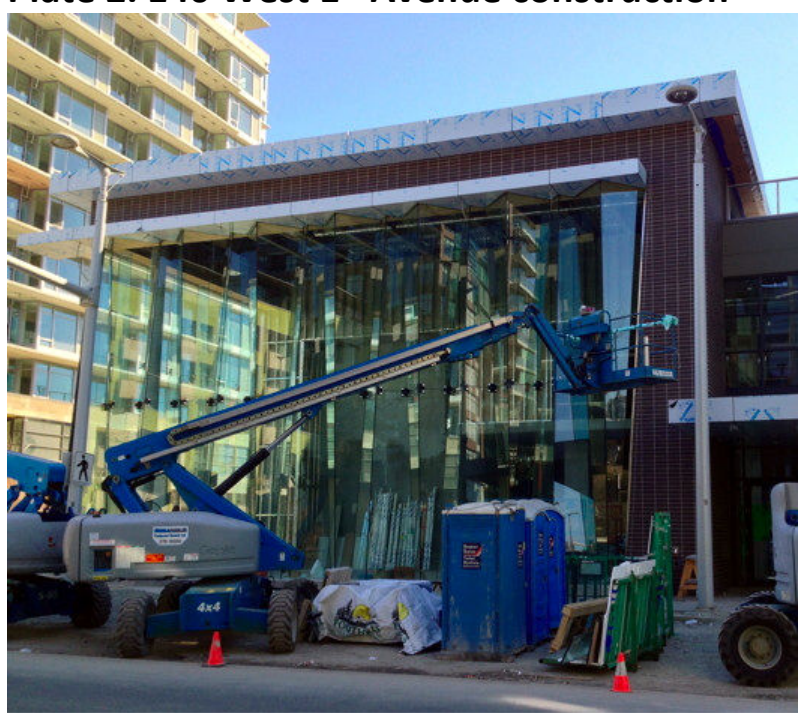

(Crilly, Wall Centre False Creek, 2013)

\section{Venue Description}

140 West $1^{\text {st }}$ Avenue is the street address and working name for a 250 -seat black box studio theatre that is under construction in the Southeast False Creek area of the Mount Pleasant neighbourhood in the City of Vancouver. The theatre and an accompanying 44,000 square foot office and production space were purpose-built to house the Vancouver Playhouse Theatre Company, however the company ceased operation prior to project completion and occupancy (Vancouver Playhouse Theatre Company, 2013). The interior of the theatre, offices, and production space have not been built and only the building structure and exterior are part of the scope of work that the project's developer, Wall Financial Corporation, is undertaking as part of its construction of a four-tower mixed-use residential complex. 
The 140 West $1^{\text {st }}$ Avenue theatre, offices, and production space were created via a Community Amenity Contribution (CACs) that were secured by the City from Wall Financial Corporation when it assembled and rezoned the property. The change in zoning from industrial to mixeduse comprehensive development produced a significant CAC and this was applied to the in-kind creation of the cultural facility (City of Vancouver, 2010). The original intent was that the Vancouver Playhouse Theatre Company would move its head offices and production shop to the new facility and end its practice of leasing space. The theatre would become a second stage for the Playhouse to present its own work. The facility would have remained the property of the City of Vancouver and operated in a long-term lease agreement with the Vancouver Playhouse Theatre Company, though it was unclear whether the theatre would be operated by the City of Vancouver' Civic Theatres operational unit, which runs the Orpheum Theatre, Vancouver Playhouse Theatre, and the Queen Elizabeth Theatre.

\section{Further Discussion}

The Southeast False Creek neighbourhood is undergoing significant redevelopment and change as it transitions from a low-density and largely vacant industrial district into a high-density mixed-use residential neighbourhood. The Olympic Village constitutes the heart of the Southeast False Creek (SEFC) neighbourhood and the subject site at 140 West $1^{\text {st }}$ Avenue is immediately adjacent. The SEFC Official Development Plan locates most of the commercial activity of the neighbourhood around the public plaza in the centre of the Olympic Village and Manitoba Street, which acts as a north-south spine (City of Vancouver, 2013). The choice to locate a theatre and a major cultural production facility adjacent to the Olympic Village will help enliven the new neighbourhood and add employment to an otherwise predominantly residential neighbourhood. The theatre will be large enough to put on professional productions of theatre, dance, and music, and with a capacity of 250 seats, it will act as a significant trip generator for visits to local restaurants and businesses. The theatre is located at a mid-block pedestrian mews, which features a continuous pedestrian thoroughfare from $2^{\text {nd }}$ Avenue down to the waterfront and a plaza in front of the theatre itself. 
140 West $1^{\text {st }}$ Avenue is a cautionary example of how a well thought-through plan for the creation of a cultural facility for one of the city's leading theatre companies can be derailed. The 2008 recession delayed construction of the Wall Centre False Creek development, of which the 140 West $1^{\text {st }}$ Avenue cultural facility is a part. The original offices and production shop of the Vancouver Playhouse Theatre Company were demolished to make way for the Wall Centre False Creek development and as a resulted in the Vancouver Playhouse Theatre Company had to take secure expensive short-term leases on nearby buildings. Matters were made worse when the building they had leased was itself closed for demolition of a new development and the Vancouver Playhouse Theatre Company had to scramble to secure temporary premises. These added costs proved to be too great a burden to allow the company to continue operating as a going concern, despite a bail-out by the City in the year before the Playhouse declared bankruptcy (Lee \& Hall, 2012). The City has put out a tenant call for a non-profit organisation to operate the theatre and utilize the 44,000 square-foot facility. The leading respondent to the tenant call was a joint application by the Arts Club Theatre Company, Pacific Theatre Company, and Bard on the Beach to run the theatre and utilize the remaining space for rehearsal halls, costume and prop storage, and office space (Hoekstra, 2012). 


\section{Carousel Studio Theatre}

\begin{tabular}{|c|c|c|c|c|c|c|}
\hline Name & Type & Size & Location & Operator & $\begin{array}{l}\text { New vs } \\
\text { Renovation }\end{array}$ & Source \\
\hline $\begin{array}{l}\text { Carousel } \\
\text { Studio } \\
\text { Theatre }\end{array}$ & $\begin{array}{l}\text { Black box } \\
\text { studio } \\
\text { theatre }\end{array}$ & 49 & Fairview & $\begin{array}{l}\text { Carousel } \\
\text { Theatre for } \\
\text { Young People }\end{array}$ & Renovation & $\begin{array}{l}\text { (Carousel Theatre for } \\
\text { Young People, 2012) }\end{array}$ \\
\hline
\end{tabular}

Plate 3. Carousel Theatre Exterior

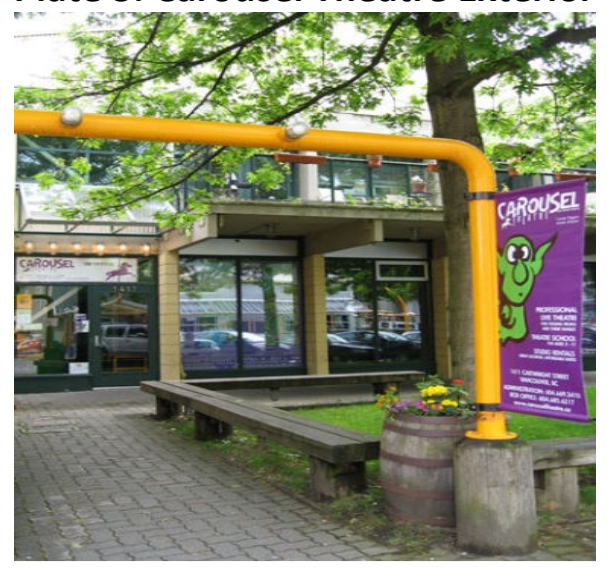

(Rijn, 2013)
Plate 4. Carousel Theatre Interior

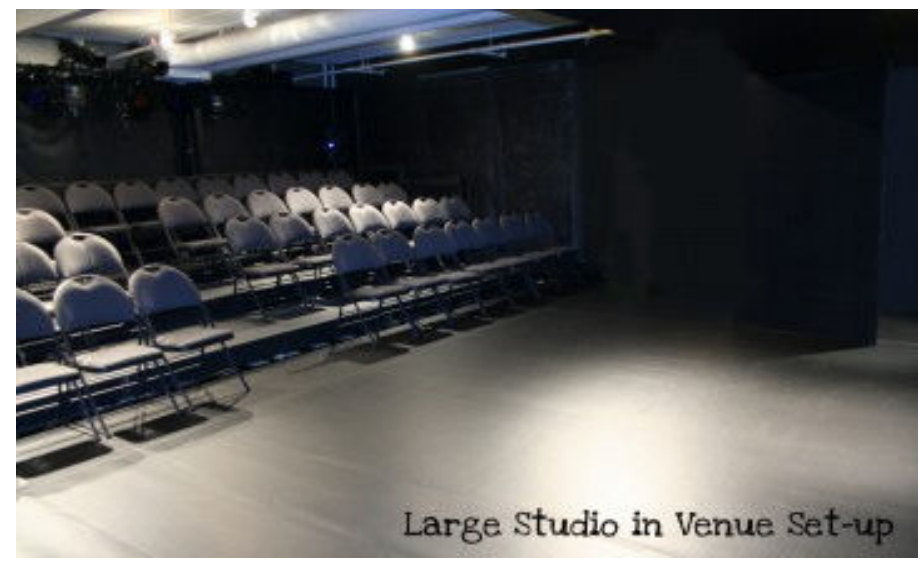

(Greater Vancouver Professional Theatre Alliance, 2013)

\section{Venue Description}

In 1993 Carousel Theatre for Young People moved to a permanent facility on Granville Island.

An existing industrial building was renovated to accommodate offices, production, and rehearsal spaces for Carousel Theatre, including a main studio that can accommodate performances in a 49-seat black box studio theatre configuration. Granville Island has converted numerous industrial buildings into facilities for the arts, including offices, rehearsal halls, and performance spaces. Carousel Theatre is the smallest permanent indoor performance space on the Island and it is used for only a portion of the year in this configuration. For the balance of the year the space functions as a closed rehearsal hall. The intimate space and clear mandate for the creation and presentation of theatrical work for young people make this a valued performing arts venue, and one that can function as an incubator performing arts venue (Carousel Theatre for Young People, 2012). 
Fei and Milton Wong Experimental Theatre

\begin{tabular}{|c|c|c|c|c|c|c|}
\hline Name & Type & Size & Location & Operator & $\begin{array}{l}\text { New vs } \\
\text { Renovation }\end{array}$ & Source \\
\hline $\begin{array}{l}\text { Fei and } \\
\text { Milton Wong } \\
\text { Experimental } \\
\text { Theatre }\end{array}$ & $\begin{array}{l}\text { Black box } \\
\text { studio } \\
\text { theatre }\end{array}$ & 440 & Downtown & $\begin{array}{l}\text { Simon Fraser } \\
\text { University }\end{array}$ & New & $\begin{array}{l}\text { (Simon Fraser } \\
\text { University, 2013) }\end{array}$ \\
\hline
\end{tabular}

Plate 5. Simon Fraser University School for the Contemporary Arts, Exterior

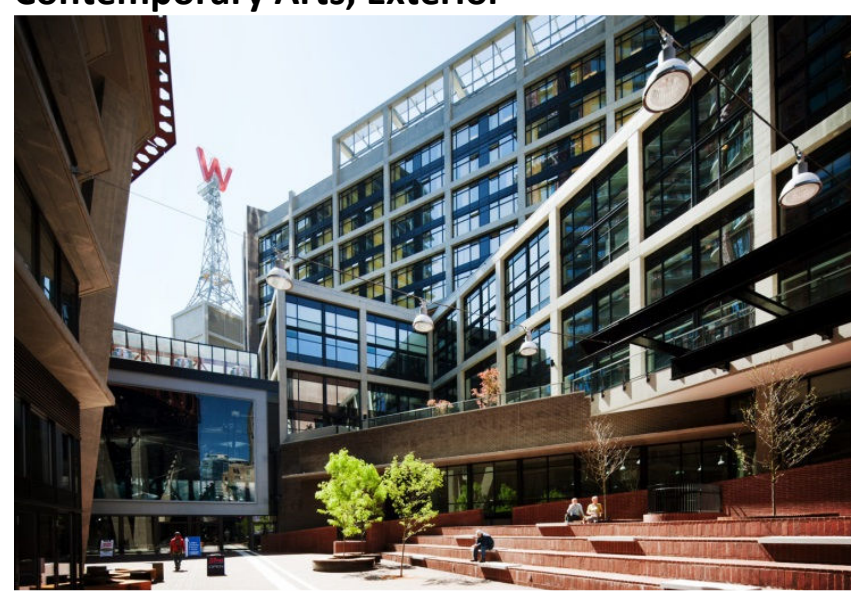

(Westbank, 2012)
Plate 6. Fei and Milton Wong Experimental Theatre, Interior

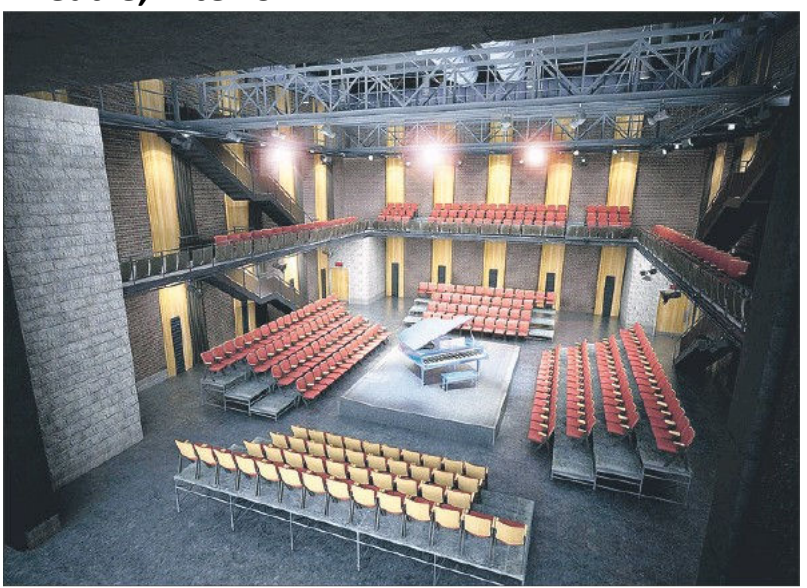

(Greater Vancouver Professional Theatre Alliance, 2012)

\section{Venue Description}

The 440-seat Fei and Milton Wong Experimental Theatre is large black block studio theatre with highly reconfigurable seating options. It was built as part of Simon Fraser University's Goldcorp School for the Contemporary Arts and designed to function as an extracurricular rental venue. The theatre is unusual in that it is entirely contained within a larger structure that includes academic space for the 1,500 students who attend Simon Fraser University, 120 low-income apartments, and a London Drugs department store. The complete Woodwards redevelopment project also includes 550 condominiums, a further 80 low-income family rental apartments, office space for the City of Vancouver, the National Film Board of Canada, and local non-profits, a grocery store, and an assortment of small retail spaces (Westbank, 2012). 
Firehall Arts Centre

\begin{tabular}{|c|c|c|c|c|c|c|}
\hline Name & Type & Size & Location & Operator & $\begin{array}{l}\text { New vs } \\
\text { Renovation }\end{array}$ & Source \\
\hline $\begin{array}{l}\text { Firehall Arts } \\
\text { Centre }\end{array}$ & $\begin{array}{l}\text { Black box } \\
\text { studio } \\
\text { theatre }\end{array}$ & 136 & $\begin{array}{l}\text { Downtown } \\
\text { East Side }\end{array}$ & $\begin{array}{l}\text { Firehall Arts } \\
\text { Centre }\end{array}$ & Renovation & $\begin{array}{l}\text { (Firehall Arts Centre, } \\
\text { 2013) }\end{array}$ \\
\hline
\end{tabular}

Plate 7. Firehall Arts Centre, Exterior

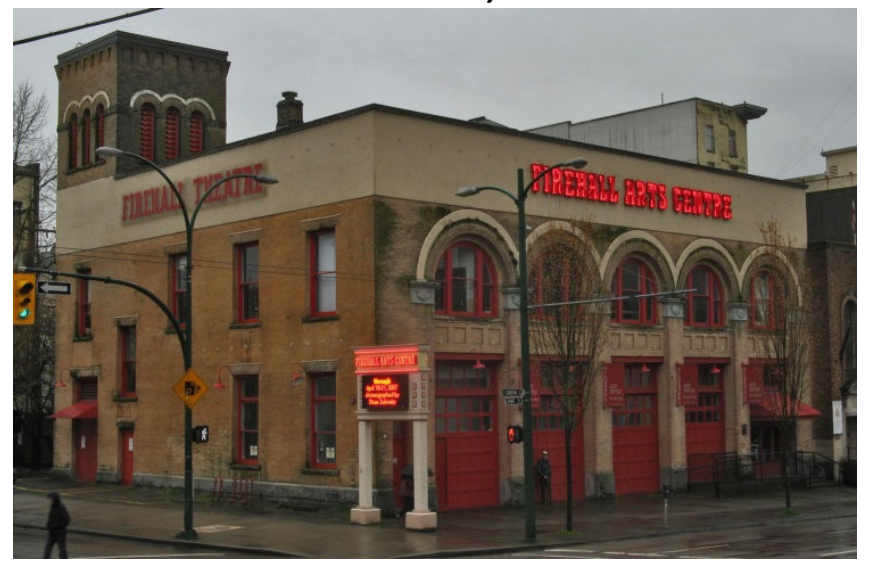

(Bobanny, 2007)

\section{Plate 8. Firehall Arts Centre, Interior}

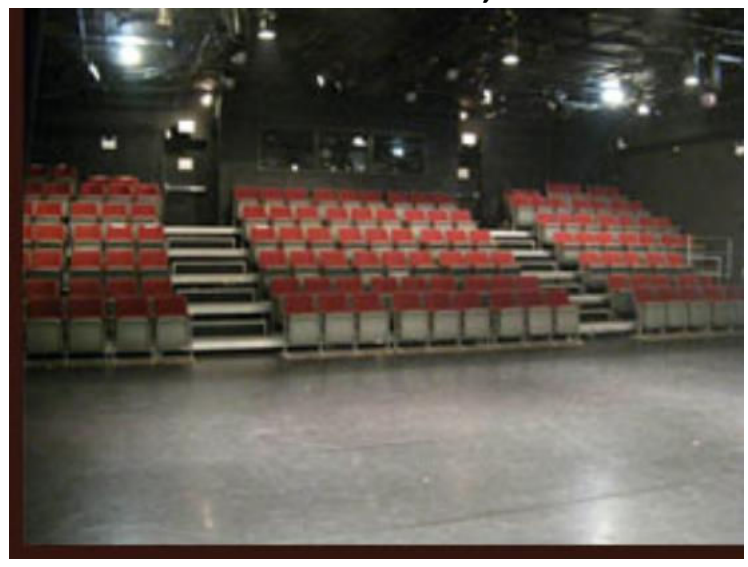

(Trip Advisor, 2013)

\section{Venue Description}

This 136-seat performing arts venue is located in a former City of Vancouver Fire Department fire hall. It was built in 1906 to permanently house the City's first motorised fire trucks and it was the first of its type in North America. It was renovated to become a theatre in 1975 and is the permanent home of these performing arts companies: Firehall Theatre Company; Touchstone Theatre; and Axis Mime, (Alliance for Arts and Culture, no date). The small, intimate space is well suited for theatre and dance, and while the seats are fixed, considerable flexibility is afforded for the staging of work by the deep, full-width stage.

The Firehall Arts Centre is located in the Downtown East Side neighbourhood of Vancouver; an area with a stable low-income population, many of whom also struggle with addiction. The Firehall Arts Centre took on a mandate for itself to produce socially-engaged art and tell relevant stories that help connect the local population and that of the broader city better understand one another (Firehall Arts Centre, 2013). 


\section{Granville Island Stage}

\begin{tabular}{|c|c|c|c|c|c|c|}
\hline Name & Type & Size & Location & Operator & $\begin{array}{l}\text { New vs } \\
\text { Renovation }\end{array}$ & Source \\
\hline $\begin{array}{l}\text { Granville } \\
\text { Island Stage }\end{array}$ & $\begin{array}{l}\text { Proscenium } \\
\text { stage } \\
\text { theatre }\end{array}$ & 450 & Fairview & $\begin{array}{l}\text { Arts Club } \\
\text { Theatre } \\
\text { Company }\end{array}$ & Renovation & $\begin{array}{l}\text { (Arts Club Theatre } \\
\text { Company, 2013) }\end{array}$ \\
\hline
\end{tabular}

Plate 9. Granville Island Stage, exterior

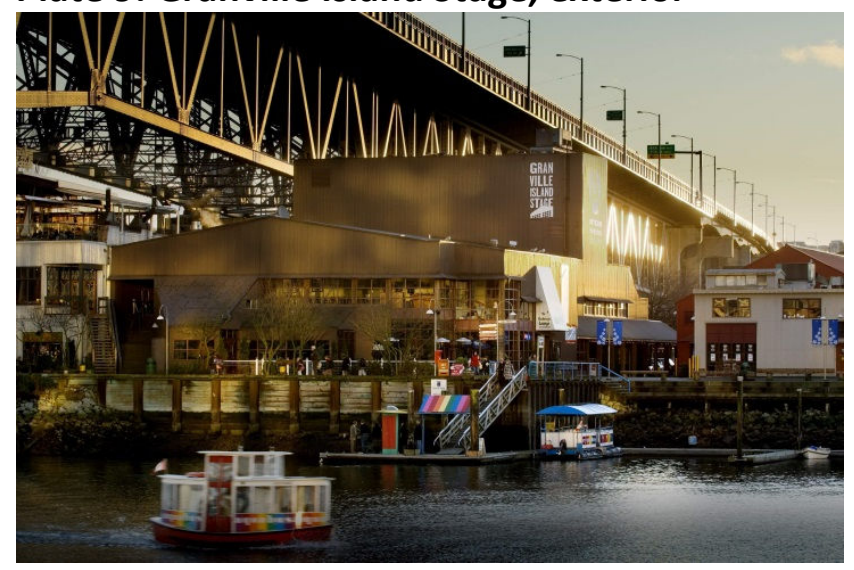

(Arts Club Theatre Company, 2013)
Plate 10. Granville Island Stage, interior

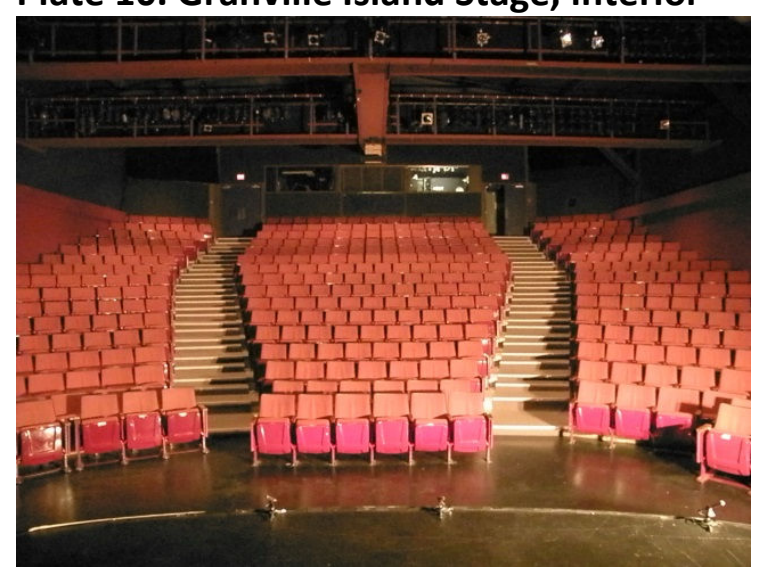

(Arts Club Theatre Company, no date)

\section{Venue Description}

The Granville Island Stage is a 450-seat proscenium stage performing arts venue located on Granville Island. The building that houses the theatre was once a factory built in the 1920s. It was renovated and opened as a theatre in 1979 as part of the redevelopment of Granville Island. The theatre is part of a larger cultural facility includes the head offices of the Arts Club Theatre Company, its rehearsal hall, box office, and the Backstage Lounge; a full-service restaurant and live music venue. Beside the Granville Island Stage are the Arts Club Theatre Company's Revue Stage, its box office back office and call centre, and the company's marketing department. The venue is used primarily for theatre and the Arts Club stages a full five-show annual season. During scheduled gaps in the season, the venue is rented for use by other performing arts companies and as a venue for weddings, graduations, and conferences (Arts Club Theatre Company, 2013). The Granville Island Stage complex is a major employer and trip generator on Granville Island and between it, and the Revue Stage, up to 1,300 patrons per day may come to the Island to attend a performance and frequent Island restaurants and shops. 
Havana Theatre

\begin{tabular}{|c|c|c|c|c|c|c|}
\hline Name & Type & Size & Location & Operator & $\begin{array}{l}\text { New vs } \\
\text { Renovation }\end{array}$ & Source \\
\hline $\begin{array}{l}\text { Havana } \\
\text { Theatre }\end{array}$ & $\begin{array}{l}\text { Black box } \\
\text { studio } \\
\text { theatre }\end{array}$ & 60 & $\begin{array}{l}\text { Grandview- } \\
\text { Woodland }\end{array}$ & $\begin{array}{l}\text { Havana } \\
\text { Restaurant }\end{array}$ & Renovation & $\begin{array}{l}\text { (Havana } \\
\text { Restaurant, } \\
\text { 2013) }\end{array}$ \\
\hline
\end{tabular}

Plate 11. Havana Restaurant, Exterior

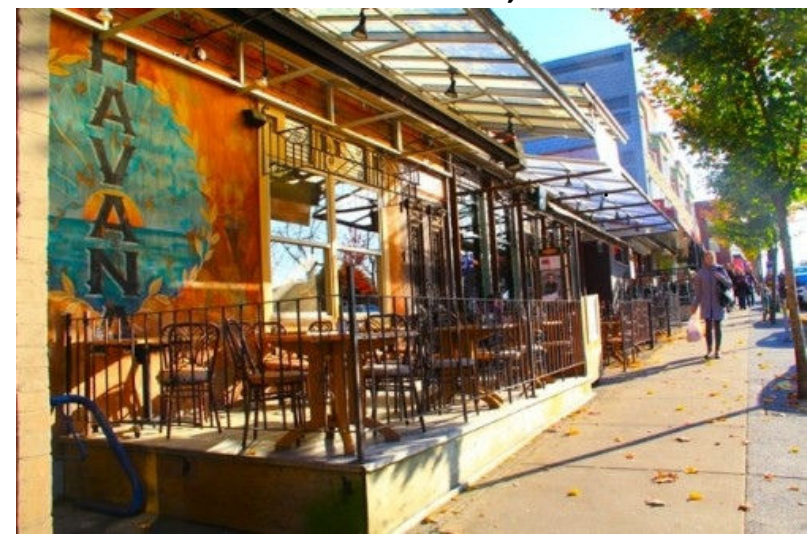

(Foodp, 2012)
Plate 12. Havana Theatre, Interior

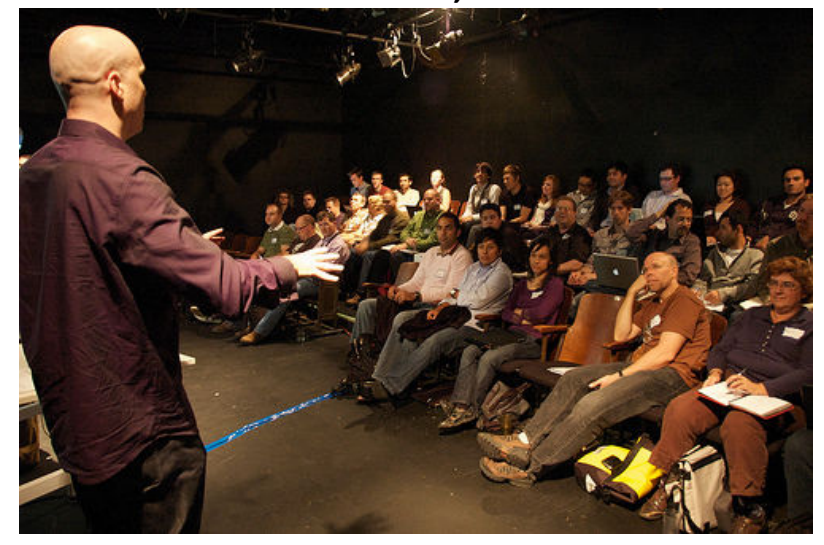

(Smith T. N., 2008)

\section{Project Description}

Havana Theatre is an award-winning 60-seat performing arts venue located on Commercial Drive in the Grandview-Woodlands neighbourhood of Vancouver. The theatre is located inside Havana Restaurant in an innovative mixed-use space that combines a lively Latin restaurant with a patio overlooking Grandview Park, and a gallery space for showcasing local talent that also functions as a lobby for theatre patrons, and the theatre itself. The 'black box' nature of the space means that there is no stage or division between the audience and the performers. Instead, three levels of seating rise from the theatre floor, upon which the actors perform. This creates an intensely intimate environment that is well-suited to character-driven performances and helps preclude the need for a substantial set, which lowers the cost of staging a production.

Havana Restaurant opened in 1996, and was purpose-built to house the theatre and gallery (Havana Restaurant, 2013). Commercial Drive has a reputation for being an inclusive, diverse, artistic, and food-driven neighbourhood, and since opening Havana Restaurant has established itself as a vibrant heart of the neighbourhood. It combines the appeal of casual fine dining and people watching from its patio, for which it has won multiple people's choice awards from local 
newspapers, with the excitement of attending a new local live theatre production and seeing the artwork of up-and-coming local artists.

\section{Further Discussion}

Havana Theatre functions in the critically important role of an 'incubator space' within the performing arts venue landscape of Vancouver. It is an inexpensive venue that offers a platform for new work to be presented by start-up theatre companies and performers. Success in this incubator venue can open a path for performers and theatre companies to move along the continuum of venues, attract larger audiences, undertake shows with larger casts of performers and greater production value, more easily secure financial resources from investors and banked profits.

The financial viability of Havana Theatre is directly tied to its intentional sharing of space with the restaurant portion of the business. This allows the theatre to be located on an expensive commercial street in a highly visible and accessible location without having to bear the cost of this wholly through ticket receipts and venue rental fees. Furthermore, theatre patrons often choose to have a drink and a meal before the play and by eating in the restaurant they avoid the anxiety of missing the start of the show. Afterwards, some patrons may remain for a late meal or a drink.

The Commercial Drive neighbourhood tangibly benefits from having Havana Theatre within its midst. Productions held at the Havana Theatre frequently have an early and late show, attracting up to 120 patrons nightly. This audience base frequently shops, eats, and drinks at Commercial Drive businesses before and after their performance at Havana Theatre. Furthermore, the eclectic nature of the venue helps shape popular the appreciation that Commercial Drive is a lively bohemian neighbourhood with a sense of place.

\section{Jericho Arts Centre}

\begin{tabular}{|c|c|c|c|c|c|c|}
\hline Name & Type & Size & Location & Operator & $\begin{array}{l}\text { New vs } \\
\text { Renovation }\end{array}$ & Source \\
\hline Jericho Arts & Black box & 135 & Point Grey & Jericho Arts & Renovation & (Friends of Jericho \\
\hline
\end{tabular}




\begin{tabular}{|l|l|l|l|l|l|}
\hline Centre & $\begin{array}{l}\text { studio } \\
\text { theatre }\end{array}$ & $\begin{array}{l}\text { Centre } \\
\text { Society }\end{array}$ & $\begin{array}{l}\text { Arts Centre Society, } \\
\text { No date) }\end{array}$ \\
\hline
\end{tabular}

Plate 13. Jericho Arts Centre, Exterior

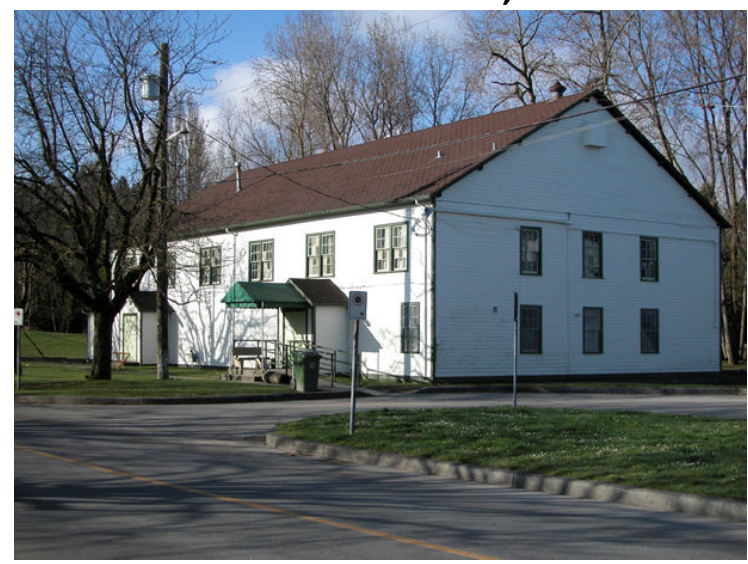

(Wolodoko, 2011)
Plate 14. Jericho Arts Centre, Interior

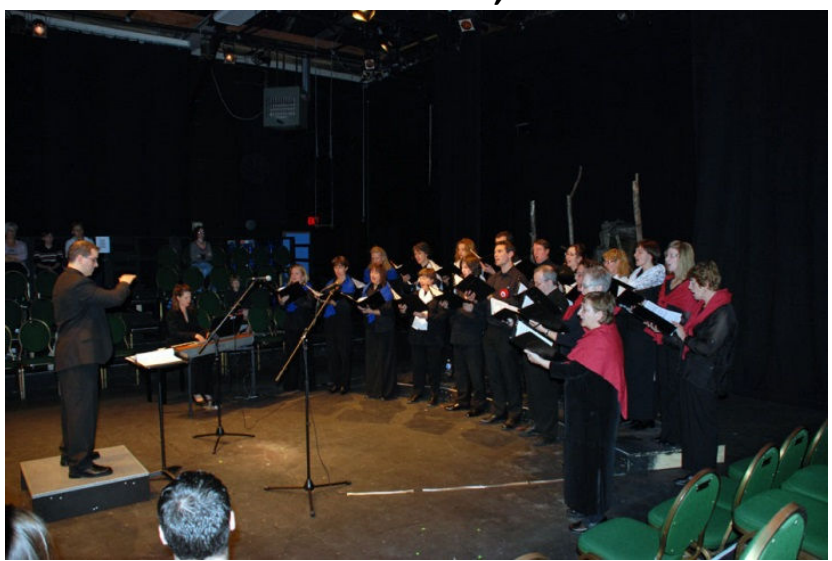

(Burgraeve, 2007)

\section{Venue Description}

The Jericho Arts Centre is an intimate 135-seat black box studio theatre that was created in 1993 by the City of Vancouver Parks Department through the renovation of a decommissioned Coast Guard building that was once a part of a large military sea plane aerodrome during the Second World War (Friends of Jericho Arts Centre Society, No date). The venue has a flexible seating configuration and no permanent stage. This allows for considerable flexibility and the ability to accommodate a variety of performing arts. The venue is the home for the United Players of Vancouver, a volunteer-based professional theatre company that produces a fiveshow season of theatre with an emphasis on casting theatre students and recent graduates. The Jericho Arts Centre is also an active and inexpensive rental venue and it has begun serving as the semi-permanent venue for Fight Change Productions; a recently founded theatre company that has established itself and has moved up the venue continuum from the Havana Theatre.

\section{Further Discussion}

The Jericho Arts Centre is a model incubator performing arts venue and an embodiment of the renovation-first policy that this proposal recommends. The Arts Centres' emphasis on hiring and supporting new talent and theatre companies allows each to gain valuable experience and 
established a track record. The highly functional yet simple - even Spartan - interior of the Jericho Arts Centre demonstrates that an incubator performing arts venue can succeed in its mandate by placing an emphasis on function over form. However, the remote location of the Jericho Arts Centre is a significant weakness. It is located far from established commercial areas on the far north-west corner of the city and it is in the midst of a public park that is surrounded by a residential neighborhood. While public automobile parking is available, the closest public transit route is 600 metres away and accessed along a steep residential street bordering a heavily wooden park that is generally poorly-lit and deserted. Furthermore, there are no restaurants or commercial services in the vicinity of the Jericho Arts Centre and as a result, the potential local economic benefits of the theatre serving as an 'anchor tenant' for a commercial district are forfeited. 
Metro Theatre

\begin{tabular}{|c|c|c|c|c|c|c|}
\hline Name & Type & Size & Location & Operator & $\begin{array}{l}\text { New vs } \\
\text { Renovation }\end{array}$ & Source \\
\hline $\begin{array}{l}\text { Metro } \\
\text { Theatre }\end{array}$ & $\begin{array}{l}\text { Proscenium } \\
\text { stage theatre }\end{array}$ & 285 & Marpole & $\begin{array}{l}\text { Metro Theatre } \\
\text { Co-op }\end{array}$ & Renovation & $\begin{array}{l}\text { (Metro Theatre } \\
\text { Vancouver, 2013) }\end{array}$ \\
\hline
\end{tabular}

Plate 15. Metro Theatre, Exterior

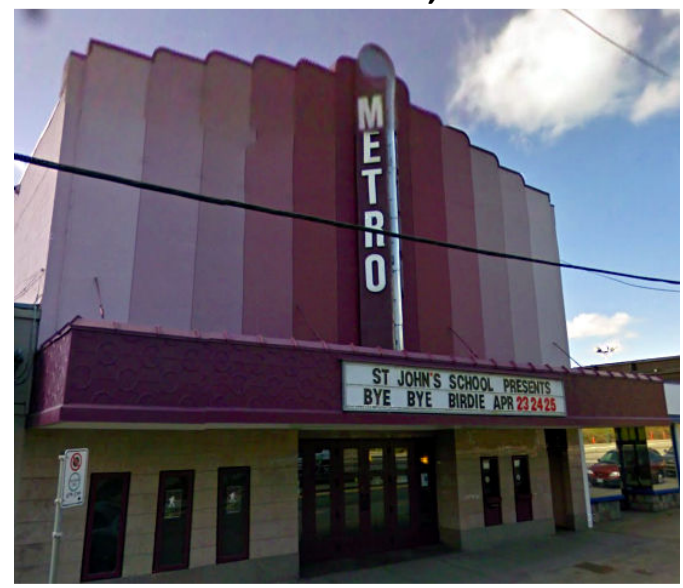

(Google, 2013)
Plate 16. Metro Theatre, Interior

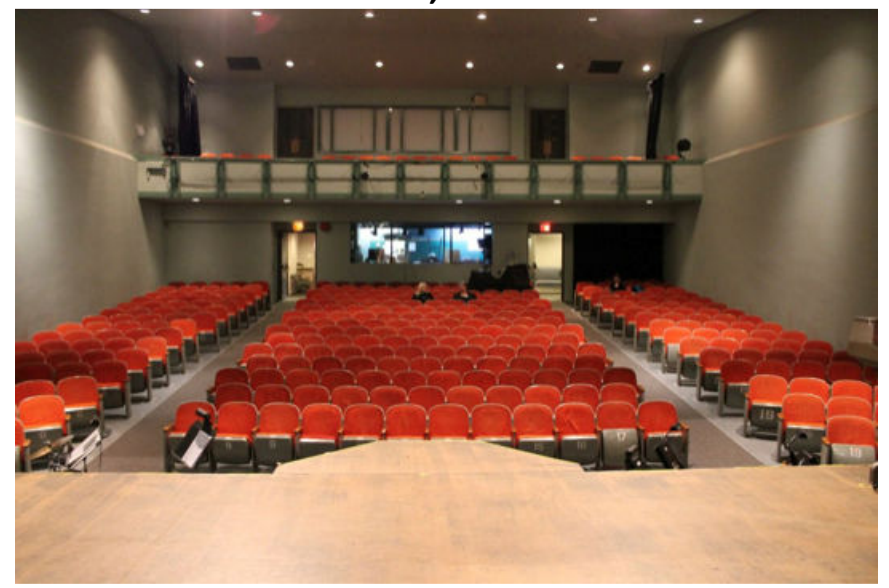

(Metro Theatre Company, 2012)

\section{Venue Description}

The 285-seat Metro Theatre is a proscenium stage performing arts venue located in the Marpole neighbourhood in the southern part of the City of Vancouver. The venue was originally built to be a movie theatre and it was later renovated to accommodate theatre and other art forms. The Metro Theatre Company produces an eight-show season and also rents out the venue for plays, concerts, and film screenings presented by other companies, as well as the work of the nearby St. John's high school. The 'anchor tenant' economic potential for the venue is limited due to it being more than 500 metres away from the pedestrian-oriented commercial core the Marpole neighbourhood. Instead, the Metro Theatre is surrounded by a pedestrianunfriendly stretch of retail that includes a car dealership, motor-inn, and a bar and liquor store with a rough reputation, while the street itself is heavily trafficked by vehicles that accelerate to climb a flying on/off-ramp to the nearby Arthur Lang Bridge. Redevelopment and streetscape improvements are a focus of the Marpole Community Plan (City of Vancouver, 2013). 


\section{Norman Rothstein Theatre}

\begin{tabular}{|c|c|c|c|c|c|c|}
\hline Name & Type & Size & Location & Operator & $\begin{array}{l}\text { New vs } \\
\text { Renovation }\end{array}$ & Source \\
\hline $\begin{array}{l}\text { Norman } \\
\text { Rothstein } \\
\text { Theatre }\end{array}$ & $\begin{array}{l}\text { Proscenium } \\
\text { stage theatre }\end{array}$ & 318 & Oakridge & $\begin{array}{l}\text { Jewish Community } \\
\text { Centre of Greater } \\
\text { Vancouver }\end{array}$ & New & $\begin{array}{l}\text { (Jewish Community } \\
\text { Centre of Greater } \\
\text { Vancouver, 2013) }\end{array}$ \\
\hline
\end{tabular}

Plate 17. Norman Rothstein Theatre, Exterior

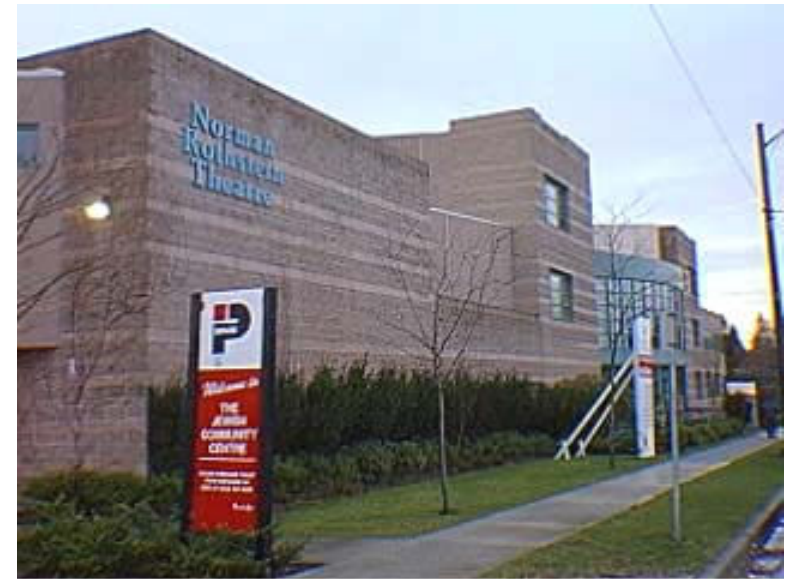

(City of Vancouver, no date)
Plate 18. Norman Rothstein Theatre, Interior

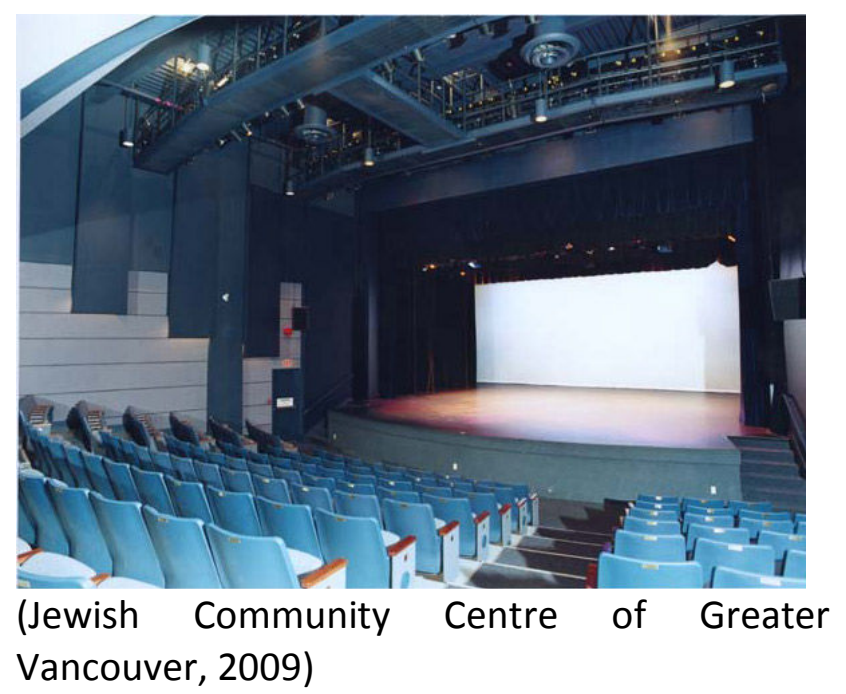

\section{Venue Description}

The 318-seat Norman Rothstein Theatre is a purpose-built proscenium stage performing arts venue located within the Jewish Community Centre of Greater Vancouver. It was designed to accommodate many types of performing arts and includes a stage with dance-friendly floorboards, a grand piano, cinema screen and projector, state of the art sound for live concerts, and extensive lighting and production equipment for theatre and opera (Jewish Community Centre of Greater Vancouver, 2009). The venue is used to present performances associated with the Jewish Community Centre and it is also a rental venue specifically designed and priced to let performing arts companies "graduate" to a large state-of-the-art facility after having been nurtured by small incubator and medium-sized venues. The Marpole Community Plan and the Oakridge Mall redevelopment plan both envision significant new mixed-use residential and retail intensification in the vicinity of the Norman Rothstein Theatre and it will act as an 'anchor tenant' for this evolving neighbourhood centre (City of Vancouver, 2013). 
Orpheum Annex

\begin{tabular}{|c|c|c|c|c|c|c|}
\hline Name & Type & Size & Location & Operator & $\begin{array}{l}\text { New vs } \\
\text { Renovation }\end{array}$ & Source \\
\hline $\begin{array}{l}\text { Orpheum } \\
\text { Annex }\end{array}$ & $\begin{array}{l}\text { Black box } \\
\text { studio } \\
\text { theatre }\end{array}$ & 193 & Downtown & $\begin{array}{l}\text { The Vancouver } \\
\text { Symphony } \\
\text { Orchestra }\end{array}$ & New & $\begin{array}{l}\text { (City of Vancouver, } \\
\text { 2012) }\end{array}$ \\
\hline
\end{tabular}

Plate 19. Orpheum

Annex, Exterior

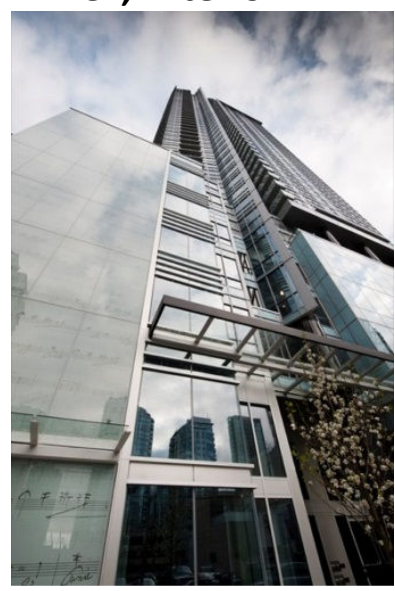

(Matheson \&

Goldstein, 2010)
Plate 20. Orpheum Annex, Interior

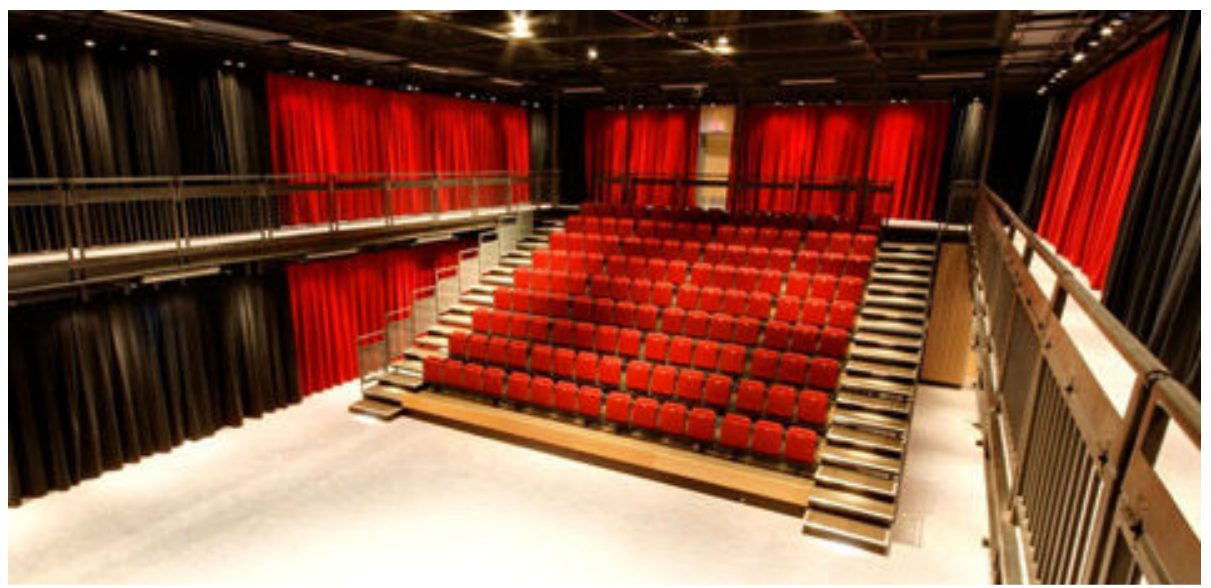

(Vancouver Symphony Orchestra, 2013)

\section{Venue Description}

The Orpheum Annex is a 193-seat performing arts venue that caters primarily to orchestral performances and it located in downtown Vancouver. It is owned by the City of Vancouver, operated by the Vancouver Symphony Orchestra (VSO), and created through a Community Amenity Contribution secured for the rezoning of the property for the Capitol Residences development by Wall Financial Corporation. The venue has a fixed-but retractable tiered seating area that offers significant flexibility. The venue was very recently completed and to date it is primarily used as a rehearsal space for the VSO. What is most significant about the venue is that it is part of larger collection of cultural facilities catering to classical music. The Community Amenity Contribution that created the Orpheum Annex was large enough to also create a second performing arts venue on site - Pyatt Hall - as well as the VSO School of Music. All are immediately adjacent to the 2,600-seat Orpheum Theatre, where VSO performs. 


\section{Orpheum Theatre}

\begin{tabular}{|c|c|c|c|c|c|c|}
\hline Name & Type & Size & Location & Operator & $\begin{array}{l}\text { New vs } \\
\text { Renovation }\end{array}$ & Source \\
\hline $\begin{array}{l}\text { Orpheum } \\
\text { Theatre }\end{array}$ & $\begin{array}{l}\text { Proscenium } \\
\text { stage } \\
\text { concert hall }\end{array}$ & 2,672 & Downtown & $\begin{array}{l}\text { Civic Theatres } \\
\text { (City of } \\
\text { Vancouver) }\end{array}$ & $\begin{array}{l}\text { New (with) } \\
\text { renovations }\end{array}$ & $\begin{array}{l}\text { (City of Vancouver, } \\
\text { 2013) }\end{array}$ \\
\hline
\end{tabular}

Plate 21. Orpheum Theatre, Exterior

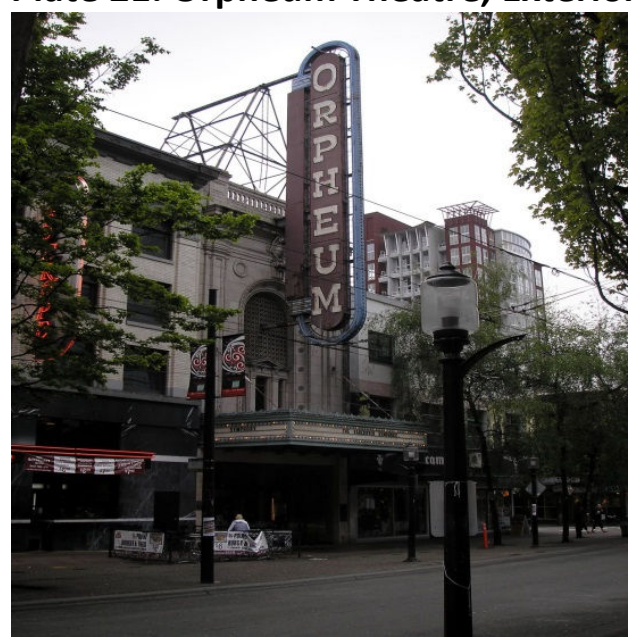

(Vaclav, 2010)
Plate 22. Orpheum Theatre, Interior

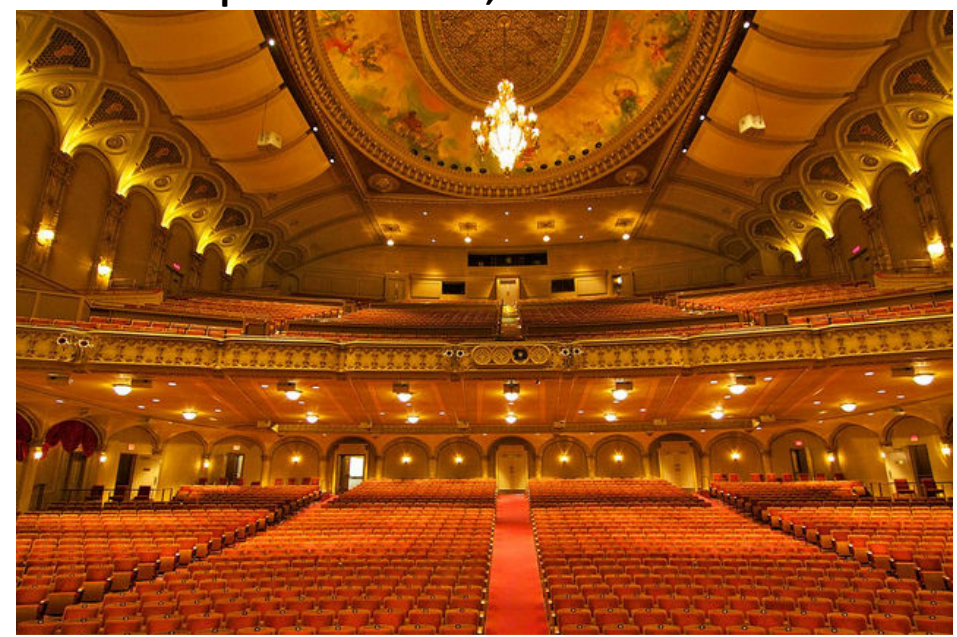

(Rickard, 2011)

\section{Venue Description}

The Orpheum Theatre is the second largest and most opulent theatre in the City of Vancouver.

The 2,672-seat proscenium stage concert hall was the largest theatre in Canada when it opened in 1927 as a purpose-built Vaudeville theatre (City of Vancouver, 2013). It later was converted to cinema while still retaining the ability to host concerts and theatre. In the early 1970s the theatre was in danger of being gutted by its owner Famous Players and converted into a multiplex movie theatre. Instead a successful grassroots 'Save the Orpheum' campaign led the City to purchase the theatre in 1974. It closed for extensive aesthetic and structural renovations and opened as a City-owned venue in 1977 and was recognized as a National Historic Site in 1979 (Parks Canada, 1979). The Orpheum is routinely used as a rental venue for concerts and graduation ceremonies, and it is the permanent home of the Vancouver Symphony Orchestra. The venue is a major activity generator for downtown Vancouver and its large capacity results in a significant driver of economic activity in the form of restaurant and bar patronage. 


\section{Pacific Theatre}

\begin{tabular}{|c|c|c|c|c|c|c|}
\hline Name & Type & Size & Location & Operator & $\begin{array}{l}\text { New vs } \\
\text { Renovation }\end{array}$ & Source \\
\hline $\begin{array}{l}\text { Pacific } \\
\text { Theatre }\end{array}$ & $\begin{array}{l}\text { Black box } \\
\text { studio } \\
\text { theatre }\end{array}$ & 128 & Fairview & Pacific Theatre & Renovation & $\begin{array}{l}\text { (Pacific Theatre, } \\
\text { 2013) }\end{array}$ \\
\hline
\end{tabular}

Plate 23. Pacific Theatre, Exterior

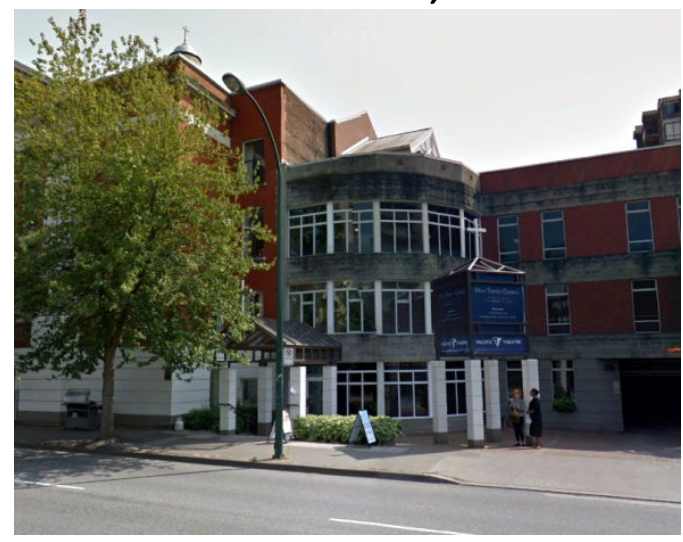

(Google, 2013)
Plate 24. Pacific Theatre, Interior

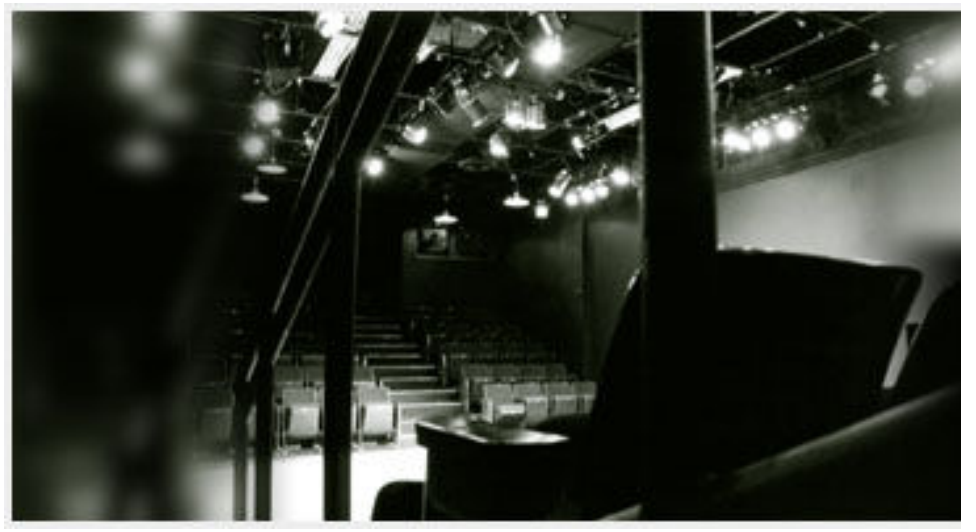

(Pacific Theatre, no date)

\section{Venue Description}

Pacific Theatre is a 128-seat performing arts venue located beneath Holy Trinity Anglican Church in the South Granville area of the Fairview neighbourhood of Vancouver. Since the venue's creation through a renovation in 1984, it has been home to Pacific Theatre Company, which produces work with positive Christian themes. The venue configuration is defined by its 'alley cat' seating configuration - the only one in Vancouver - in which two banks of seats face one another with a long wide stage in between (Pacific Theatre, 2013). This is a variation of the 'Theatre in the Round' in which the audience surrounds the stage on multiple sides, resulting in a more naturalistic performance style. Pacific Theatre is located one block away from Granville Street, which is the neighourhood's thriving commercial high street, and the Arts Club Theatre Company's Stanley Industrial Alliance Stage. Between these two venues there are nearly 900 audience seats and these act as significant 'anchor tenants' for the neighbourhood and its restaurants and shops.

\section{PAL Theatre}

\begin{tabular}{|c|c|c|c|c|c|c|}
\hline Name & Type & Size & Location & Operator & $\begin{array}{l}\text { New vs } \\
\text { Renovation }\end{array}$ & Source \\
\hline
\end{tabular}




\begin{tabular}{|l|l|l|l|l|l|l|}
\hline $\begin{array}{l}\text { PAL } \\
\text { Theatre }\end{array}$ & $\begin{array}{l}\text { Black box } \\
\text { studio } \\
\text { theatre }\end{array}$ & 120 & $\begin{array}{l}\text { Coal } \\
\text { Harbour }\end{array}$ & $\begin{array}{l}\text { Performing Arts } \\
\text { Lodge }\end{array}$ & New & $\begin{array}{l}\text { Performing Arts } \\
\text { Lodge Society, 2010) }\end{array}$ \\
\hline
\end{tabular}

Plate 25. PAL Theatre, Exterior

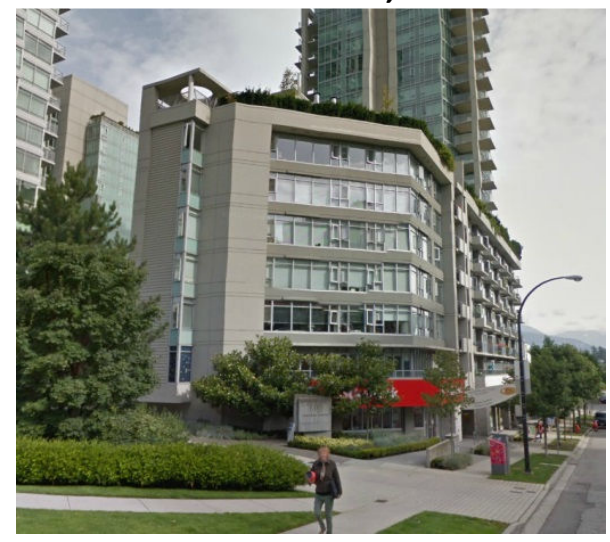

(Google, 2013)
Plate 26. PAL Theatre, Interior

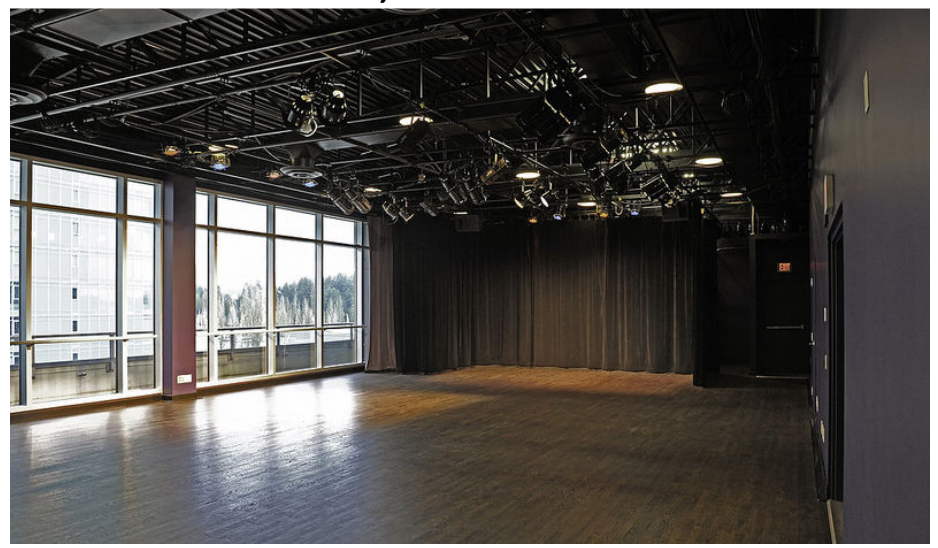

(Woods, 2013)

\section{Venue Description}

The 120-seat Performing Arts Lodge (PAL) Theatre is a purpose-built black box studio theatre located in the Coal Harbour neighbourhood of Vancouver. It is a highly unusual venue by virtue of the fact that the theatre is on the top floor of an apartment building. The PAL Theatre building is a housing co-operative for people who make their living in the performing arts sector and the theatre is run and managed by the co-operative's members. When the master planning for the Coal Harbour neighbourhood took place between Marathon Realty, Aspac, and the City, there was a policy agreed to that would include $20 \%$ non-market affordable housing as well as public amenities, both of which would be financed via CACs (Punter, 2003). The opportunity arose to address both goals on a single site when the Performing Arts Lodge Society won the competitive bid to found a co-operative on the site, which had been reserved by Marathon Realty for a non-market housing building. The building's architects surprised everyone by placing the theatre on the roof to allow audiences to enjoy lovely city views during intermission from the theatre's rooftop terrace (Performing Arts Lodge Society, 2010).

\section{Performance Works}

\begin{tabular}{|c|c|c|c|c|c|c|}
\hline Name & Type & Size & Location & Operator & $\begin{array}{l}\text { New vs } \\
\text { Renovation }\end{array}$ & Source \\
\hline $\begin{array}{l}\text { Performance } \\
\text { Works }\end{array}$ & $\begin{array}{l}\text { Black box } \\
\text { studio }\end{array}$ & 150 & Fairview & $\begin{array}{l}\text { Granville Island } \\
\text { Cultural Society }\end{array}$ & Renovation & $\begin{array}{l}\text { (Performance Works, } \\
\text { 2013) }\end{array}$ \\
\hline
\end{tabular}


Plate 27. Performance Works, Exterior Plate 28. Performance Works, Interior

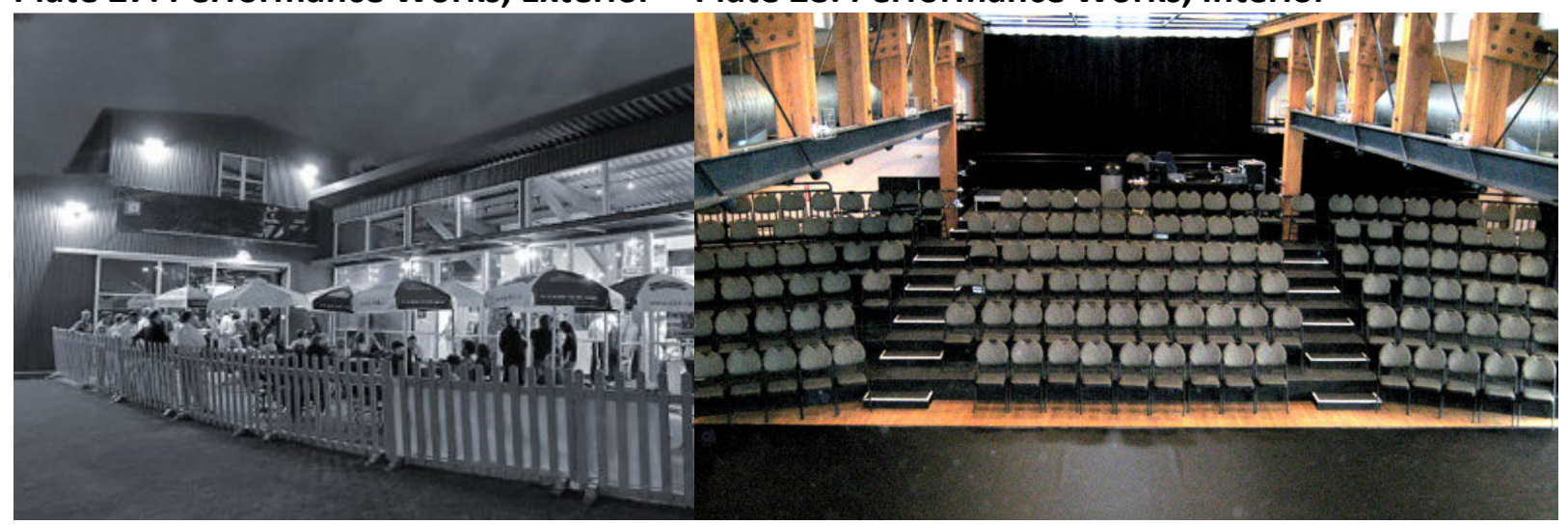

(Savory Chef Catering, no date) $\quad$ (Savory Chef Catering, no date)

\section{Venue Description}

Performance Works is a versatile 150 -seat black box theatre located on Granville Island in the city's Fairview neighbourhood. The facility is a dedicated rental venue operated by the Granville Island Cultural Society and it routinely hosts theatre, dance, concerts, weddings, and conferences (Performance Works, 2013). The building was originally a machine shop built in the 1920s while Granville Island was known as Industrial Island and it was renovated in the late 1970s to become a performing arts facility. An innovative feature of the venue is that one side of the audience chamber is made up of floor-to-ceiling glass industrial doors. The riser seating in the venue can be set up to view out through the open hangar-like doorway and entire productions have taken place outdoors in front of - and incorporating - a large grass hill beside Performance Works while the audience remains indoors. Due to is audience capacity of 150 persons, which can increase to more than 200 for standing-only production, Performance Works is not classified as an incubator performing arts venue in this report. Due to its seating and staging flexibility, it can function in the role of a small, intimate venue when required. 


\section{Pyatt Hall}

\begin{tabular}{|c|c|c|c|c|c|c|}
\hline Name & Type & Size & Location & Operator & $\begin{array}{l}\text { New vs } \\
\text { Renovation }\end{array}$ & Source \\
\hline Pyatt Hall & $\begin{array}{l}\text { Recital } \\
\text { Hall }\end{array}$ & 120 & Downtown & $\begin{array}{l}\text { Vancouver } \\
\text { Symphony } \\
\text { Orchestra School } \\
\text { of Music }\end{array}$ & New & $\begin{array}{l}\text { (Vancouver } \\
\text { Symphony School of } \\
\text { Music, 2013) }\end{array}$ \\
\hline
\end{tabular}

Plate 29. Pyatt Hall, Exterior

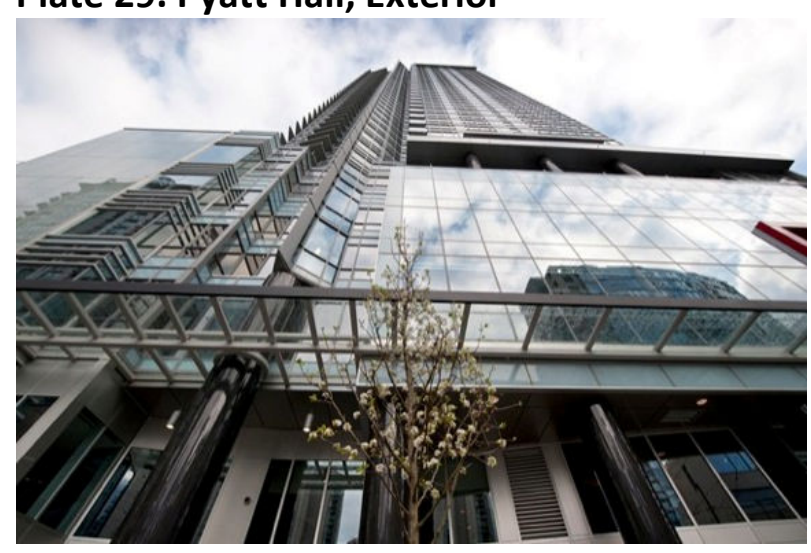

(Matheson \& Goldstein, 2010)
Plate 30. Pyatt Hall, Interior

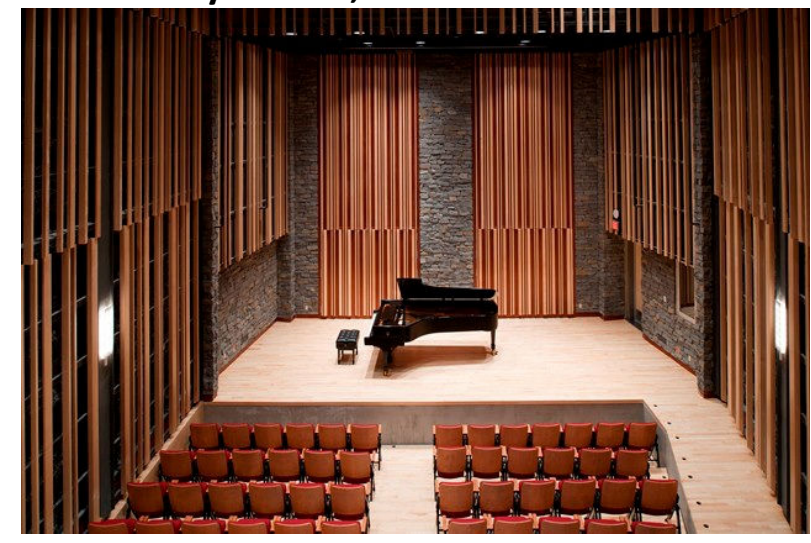

(Vancouver Symphony Orchestra, 2012)

\section{Venue Description}

Pyatt Hall is a purpose-built 120-seat recital hall for classical music, choral performances, and spoken word. It is owned by the City of Vancouver, operated by the Vancouver Symphony Orchestra (VSO), and created through a Community Amenity Contribution secured for the rezoning of the property for the Capitol Residences development by Wall Financial Corporation. The venue has virtually perfect acoustics and flexible seating that can be configured for sitdown table service or classic theatre arrangement. The venue was very recently completed and to date it is primarily used as a performance space for the Vancouver Symphony Orchestra School of Music, though it is available for rent. What is most significant about the venue is that it is part of larger collection of cultural facilities catering to classical music. The Community Amenity Contribution that created the Pyatt Hall was large enough to also create a second performing arts venue on site - The Orpheum Annex - as well as the VSO School of Music. All are immediately adjacent to the 2,600-seat Orpheum Theatre, where VSO performs. 


\section{Queen Elizabeth Theatre}

\begin{tabular}{|c|c|c|c|c|c|c|}
\hline Name & Type & Size & Location & Operator & $\begin{array}{l}\text { New vs } \\
\text { Renovation }\end{array}$ & Source \\
\hline $\begin{array}{l}\text { Queen } \\
\text { Elizabeth } \\
\text { Theatre }\end{array}$ & $\begin{array}{l}\text { Proscenium } \\
\text { stage opera } \\
\text { house }\end{array}$ & 2,765 & Downtown & $\begin{array}{l}\text { Civic Theatres } \\
\text { (City of } \\
\text { Vancouver) }\end{array}$ & $\begin{array}{l}\text { New (with } \\
\text { renovations) }\end{array}$ & $\begin{array}{l}\text { (City of Vancouver, } \\
\text { 2013) }\end{array}$ \\
\hline
\end{tabular}

Plate 31. Queen Elizabeth Theatre, Exterior

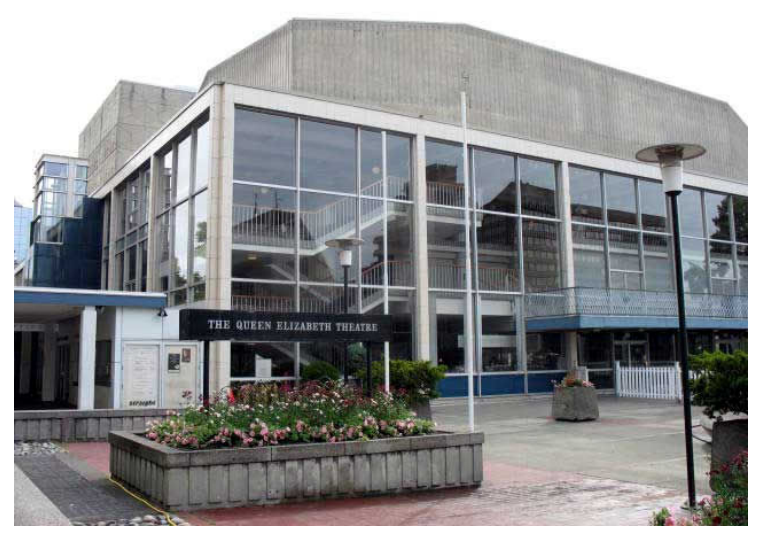

Plate 32. Queen Elizabeth Theatre, Interior

(Vaclav, 2010)

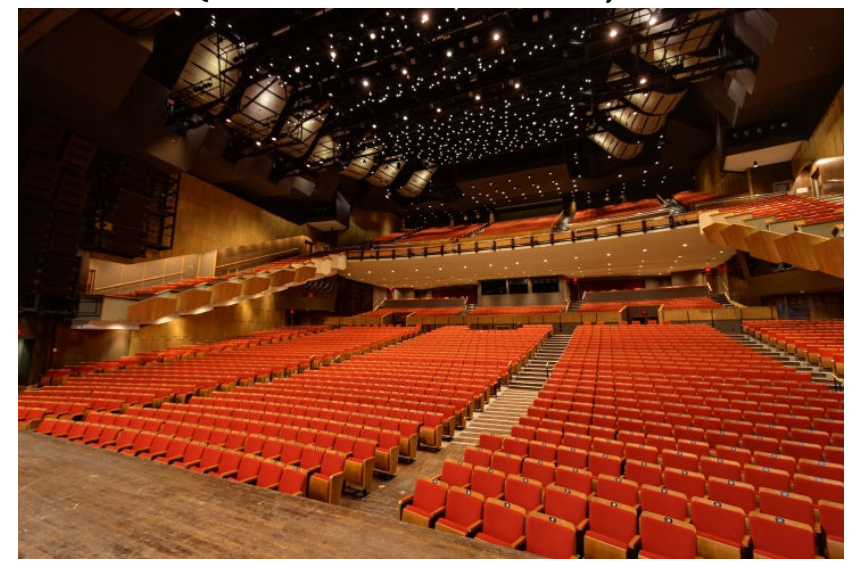

(Thoeny, 2011)

\section{Venue Description}

The 2,765-seat Queen Elizabeth Theatre is the largest performing arts venue in the City. It was purpose built as a performing arts venue, concert hall, and opera house, and it was opened in 1959 in time for a Royal visit by Queen Elizabeth, who attended a performance of the Vancouver Symphony Orchestra and after whom the theatre is named (City of Vancouver, 2013). It is the current home to Vancouver Opera and Ballet BC, and it regularly hosts concerts and touring Broadway shows. It underwent extensive renovations in time for the Expo86 World's Fair in 1986 and again prior to the 2010 Winter Olympic Games (City of Vancouver, 2013). Of particular note was the way in which the capital was raised to undertake the most recent series of renovations; the City borrowed against the future earnings it would receive through the eventual sale of the adjacent property called Larwin Park, which is a parking lot that was once housed the former Greyhound bus depot for Vancouver. 
Revue Stage

\begin{tabular}{|c|c|c|c|c|c|c|}
\hline Name & Type & Size & Location & Operator & $\begin{array}{l}\text { New vs } \\
\text { Renovation }\end{array}$ & Source \\
\hline $\begin{array}{l}\text { Revue } \\
\text { Stage }\end{array}$ & $\begin{array}{l}\text { Proscenium } \\
\text { stage } \\
\text { theatre }\end{array}$ & 198 & Fairview & $\begin{array}{l}\text { Arts Club Theatre } \\
\text { Company }\end{array}$ & Renovation & $\begin{array}{l}\text { (Arts Club Theatre } \\
\text { Company, 2013) }\end{array}$ \\
\hline
\end{tabular}

Plate 33. Revue Stage, Exterior

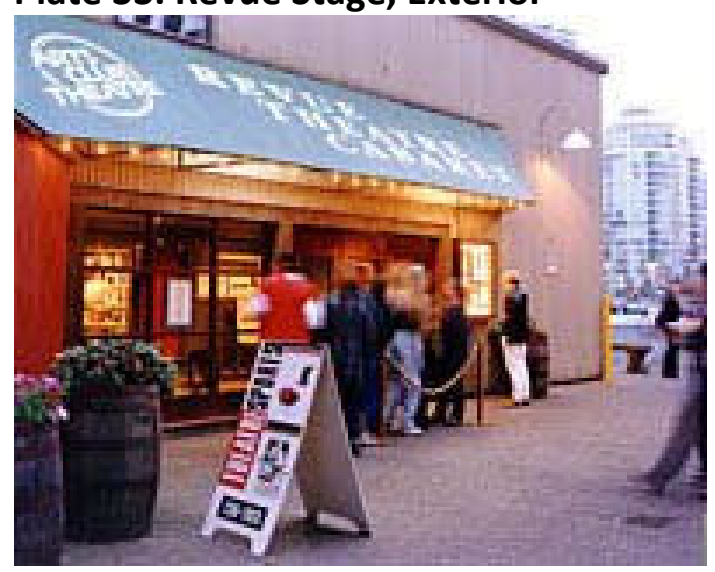

(Crystal H, 2009)
Plate 34. Revue Stage, Interior

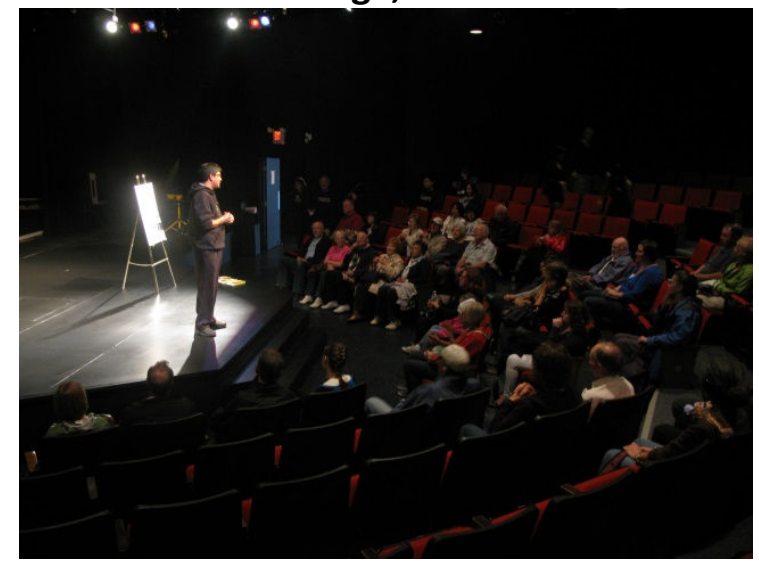

(Arts Club Theatre Company, 2010)

\section{Venue Description}

The 198-seat Revue Stage is a small- to medium-sized proscenium stage performing arts venue on Granville Island. It is owned and operated by the Arts Club Theatre Company, which presents a four-production annual season, and it is an active rental venue. The building in which the venue is located was originally a factory and built in the 1920 s when Granville Island was known as Industrial Island (Arts Club Theatre Company, 2010). In the late 1970s the building was partially renovated as part of the redevelopment of Granville Island and in 1984 the Arts Club completed renovating the shell of the building into a live theatre venue. The Arts Club produced work in the theatre until 1998 when it entered into a long-term lease agreement with Vancouver Theatresports League, which continued until 2010, when Theatresports' new Improv Centre was completed and opened. Later that year, the Revue underwent extensive renovations that saw the interior gutted and completely rebuilt (Arts Club Theatre Company, 2010). 
Roundhouse Performance Centre

\begin{tabular}{|c|c|c|c|c|c|c|}
\hline Name & Type & Size & Location & Operator & $\begin{array}{l}\text { New vs } \\
\text { Renovation }\end{array}$ & Source \\
\hline $\begin{array}{l}\text { Roundhouse } \\
\text { Performance } \\
\text { Centre }\end{array}$ & $\begin{array}{l}\text { Black box } \\
\text { studio } \\
\text { theatre }\end{array}$ & 170 & Downtown & $\begin{array}{l}\text { Roundhouse } \\
\text { Community Arts } \\
\text { and Recreation } \\
\text { Centre }\end{array}$ & Renovation & $\begin{array}{l}\text { (Roundhouse } \\
\text { Community Arts and } \\
\text { Recreation Centre, } \\
\text { 2013) }\end{array}$ \\
\hline
\end{tabular}

Plate 35. Roundhouse Performance Centre,

\section{Exterior}

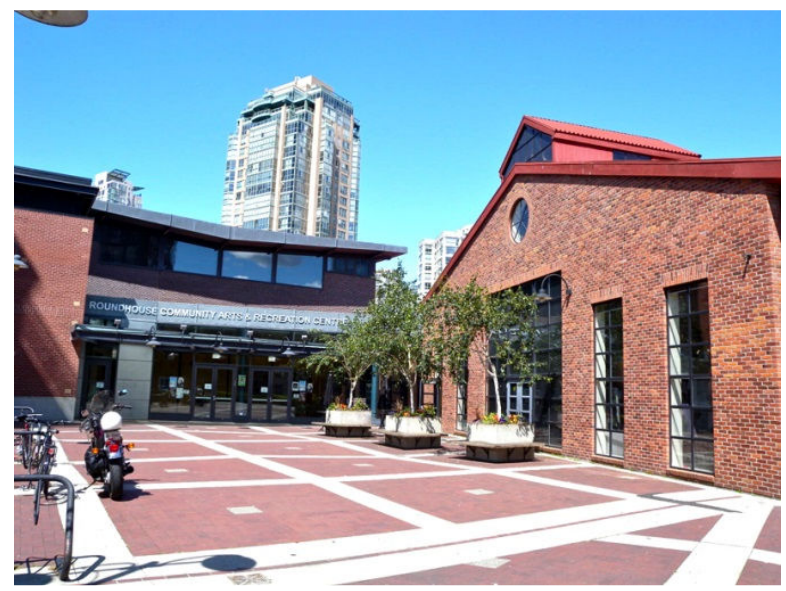

(VanCity Buzz Photo Pool)
Plate 36. Roundhouse Performance Centre, Interior

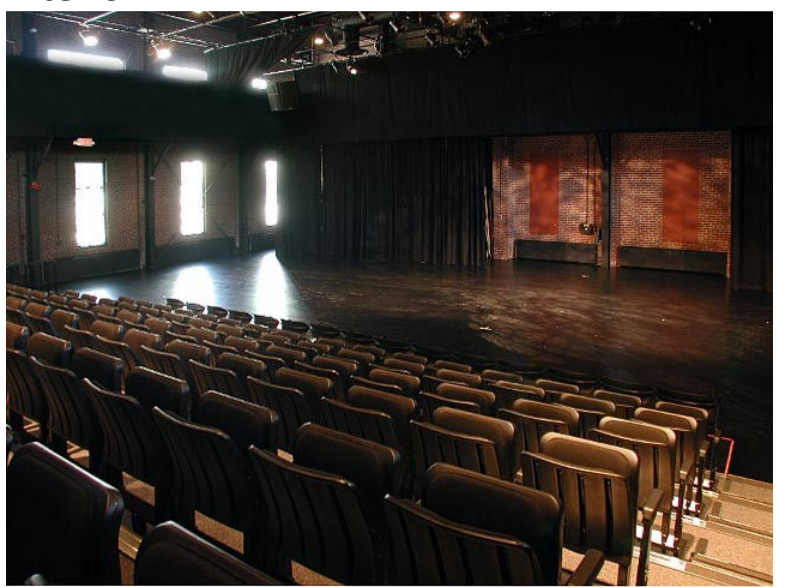

(Sinclair, 2005)

\section{Venue Description}

The Roundhouse Performance Centre is a 170-seat black box studio theatre housed in the Roundhouse Community Arts and Recreation Centre in the Yaletown area of Downtown Vancouver. The venue is highly flexible in its configuration and it can host theatre, dance, concerts, conferences, and lectures with east. The building in which the venue is located was built in 1887 as part of a roundhouse storage and maintenance yard for the Canadian Pacific Railway's trans-continental steam engines (Roundhouse Community Arts and Recreation Centre, 2013). It was converted for use as a temporary pavilion during the Expo86 World's Fair, and afterwards was extensively renovated by Concord Pacific and gifted to the City as part of its CAC obligation for the rezoning of its False Creek North lands (Punter, 2003). The venue is available for rent and it can be used in a more intimate incubator configuration with fewer seats and a smaller stage area. 


\section{Scotiabank Dance Centre}

\begin{tabular}{|c|c|c|c|c|c|c|}
\hline Name & Type & Size & Location & Operator & $\begin{array}{l}\text { New vs } \\
\text { Renovation }\end{array}$ & Source \\
\hline $\begin{array}{l}\text { Scotiabank } \\
\text { Dance } \\
\text { Centre }\end{array}$ & $\begin{array}{l}\text { Black box } \\
\text { dance } \\
\text { studio }\end{array}$ & 154 & Downtown & The Dance Centre & New & $\begin{array}{l}\text { (Scotiabank Dance } \\
\text { Centre, 2013) }\end{array}$ \\
\hline
\end{tabular}

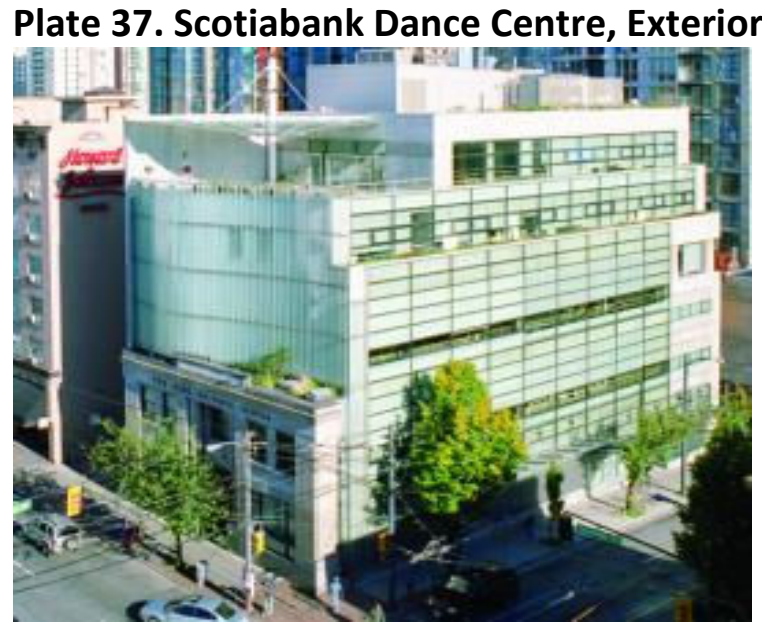

(Dance Centre, 2001)
Plate 38. Scotiabank Dance Centre, Interior

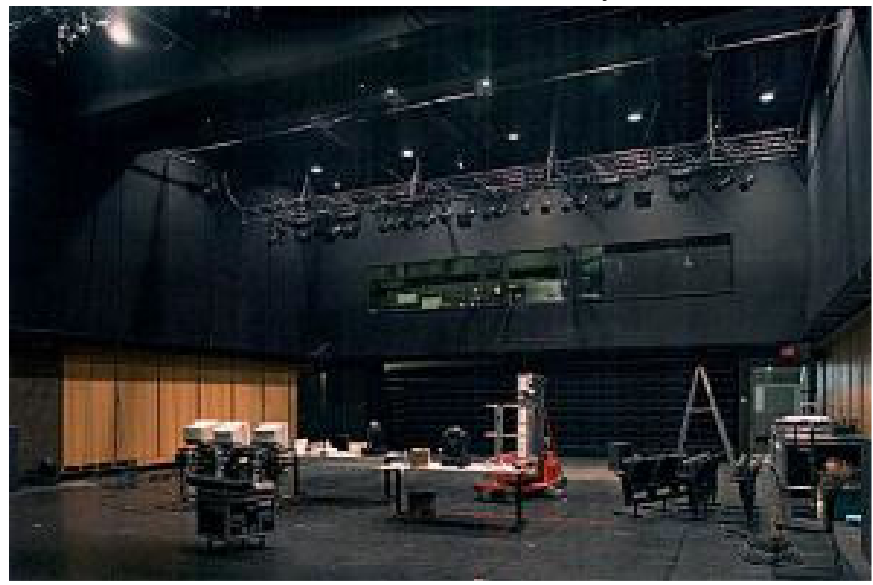

(Savory Chef, no date)

\section{Venue Description}

The Scotiabank Dance Centre is a 154-seat dance and performing arts venue located within a larger purpose-built dance facility in the downtown neighbourhood of the City of Vancouver. The venue itself is a black box studio theatre with a retractable seating system and the flexibility to configure the space in a variety of ways. The Scotiabank Dance Centre is the first facility of its kind in North America: a place where dancers can train, rehearse, and perform, while office space acts as the home base for multiple dance companies and houses an internationally-significant video archive of contemporary dance performances and dancers (Scotiabank Dance Centre, 2013). The building was purpose-built for these uses, but it retained the façade of the oldest standing branch of the Bank of Nova Scotia in Vancouver. The bank donated the property to the Dance Centre in exchange for naming rights (Punter, 2003). While the venue almost exclusively caters to dance, it is active rental venue that has also housed theatre and concerts. 
Stanley Theatre

\begin{tabular}{|c|c|c|c|c|c|c|}
\hline Name & Type & Size & Location & Operator & $\begin{array}{l}\text { New vs } \\
\text { Renovation }\end{array}$ & Source \\
\hline $\begin{array}{l}\text { Stanley } \\
\text { Industrial } \\
\text { Alliance Stage }\end{array}$ & $\begin{array}{l}\text { Proscenium } \\
\text { stage theatre }\end{array}$ & 650 & Fairview & $\begin{array}{l}\text { Arts Club } \\
\text { Theatre } \\
\text { Company }\end{array}$ & Renovation & $\begin{array}{l}\text { (Arts Club } \\
\text { Theatre } \\
\text { Company, 2013) }\end{array}$ \\
\hline
\end{tabular}

Plate 39. Stanley Theatre, Exterior

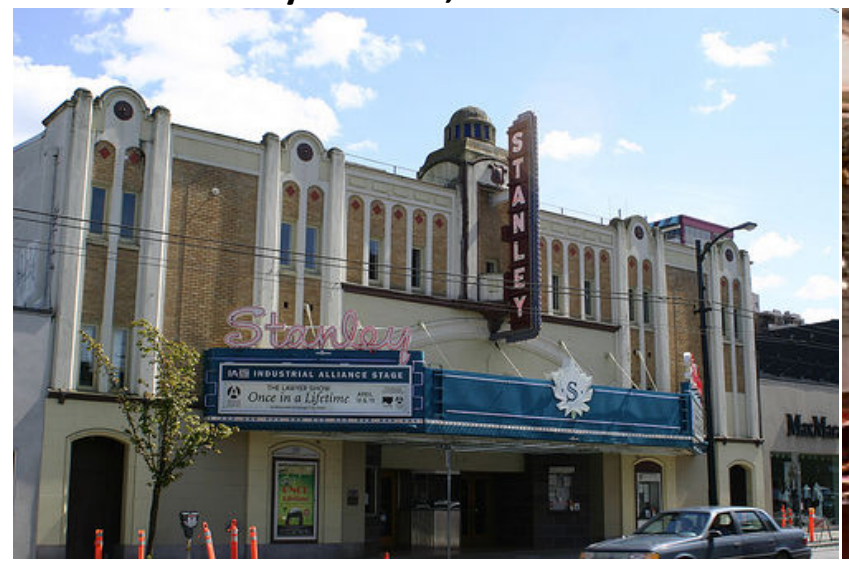

(Ang B, 2009)
Plate 40. Stanley Theatre, Interior

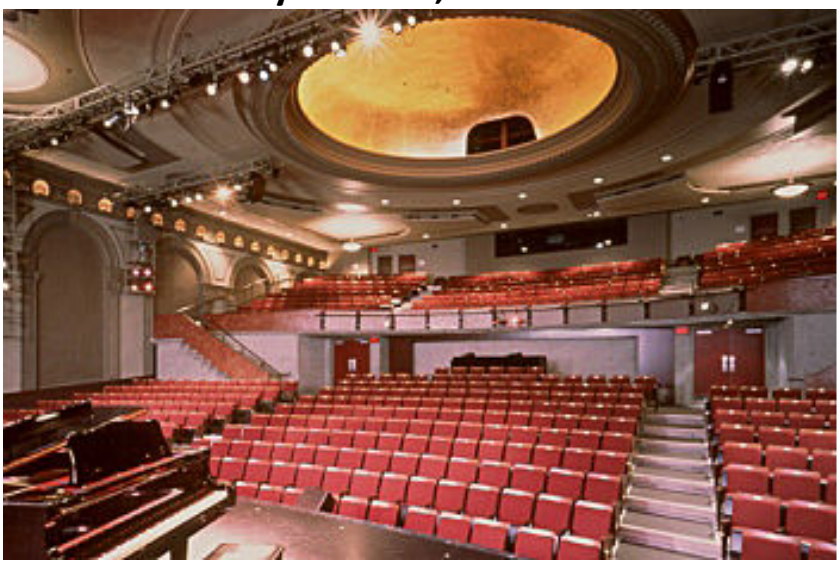

(Faulker, 1999)

\section{Project Description}

The Stanley Industrial Alliance Stage (Stanley Theatre) is a 650-seat proscenium stage theatre that is owned and operated by the Arts Club Theatre Company. The venue includes a balcony, fly tower, Art Deco and Neoclassical architectural detail, state-of-the-art theatrical lighting and sound system, and a full bar and concession in the lobby (Arts Club Theatre Company, 2013). It is located at 2750 Granville Street and acts as the cultural anchor for the vibrant South Granville neighbourhood of the City of Vancouver.

A \$2.8 million dollar renovation transformed the former Famous Players cinema into a live theatre venue and it was reopened in 1998 as the new main stage venue for the Arts Club Theatre Company. The total project budget of $\$ 5.8$ million dollars, which included the purchase of the theatre and extensive renovations, was made possible through fundraising, a commercial mortgage, and a City of Vancouver-brokered Heritage Restoration Agreement that saw the Stanley Theatre's heritage density sold to Wall Financial Corporation for use as bonus density in its One Wall Centre mixed-use hotel and residential development in downtown Vancouver 
(Vancouver Heritage Foundation, 2011) (Arts Club Theatre Company, 2013). This extra density allowed the project to go to market as the city's (then) tallest building (Punter, 2003). Since reopening in 1998, the Arts Club Theatre Company has produced more than 80 plays and musicals at the Stanley Theatre during its annual seasons and it has been rented countless times for plays, concerts, graduations, weddings, and for use as a set for film and TV productions (Arts Club Theatre Company, 2013).

The Stanley Theatre was first conceived as a venue for the Vaudeville form of live entertainment, but during its construction between 1929 and 1930 cinema took hold of the public imagination. Instead, the Stanley opened shortly after the beginning of the Great Depression with determined fanfare and was celebrated as one of the city's first cinemas. Throughout its life it was a vital neighbourhood cinema that both distracted and informed with cartoons, musicals, comedies, and newsreels during the tough days of the Depression and the Second World War; it introduced Vancouver film-goers first to 'talkies' (films with speech) and then to the blockbusters of the Golden Age of Hollywood and the wondrous arrival of colour film; and it was where generations of children experienced the bliss of Saturday matinee double-features while teenagers indulged in their first furtive forays into dating.

By the late 1980s Famous Players, which had purchased the Stanley Theatre in 1941, found that the economics of operating single screen neighbourhood cinemas was deteriorating as the industry and customers shifted to a new generation of multi-screen complexes located downtown or in suburban shopping malls. In September 1991 Famous Players closed the Stanley Theatre, leaving the larger community and local merchants -- whom had relied for six decades upon the theatre to draw customers - unsure of what lay ahead for the Stanley and whether its doors had shut for good.

Concerned citizens and local merchants joined members of the community and the arts and cultural sectors to form the Stanley Theatre Society and launched a successful 'Save our Stanley' grassroots campaign to preserve the building from demolition or conversion and, 
ultimately, allow its purchase with the intent of renovation and continued use. The Society and the Arts Club Theatre Company succeeded in purchasing the theatre in 1997, and in 1998, after a year of extensive renovation and upgrades the Stanley Theatre reopened as the new mainstage venue of the Arts Club with a sold-out run of the musical revue Swing - a fitting nostalgic tribute to the Stanley Theatre's heyday era in the 1940s.

\section{Further Discussion}

The Stanley Theatre is significant because it pioneered the sale of transferable heritage density as a tool for financing the restoration of a performing arts venue (Punter, 2003). The success of the Stanley project and the positive impact that it immediately had on the South Granville neighbourhood prompted the creation of numerous new performing arts and cultural venues using some form of growth financing tools (CACs, Heritage Restoration Agreements, and Density Bonusing).

The larger stage and audience capacity of the Stanley Theatre offered the Arts Club Theatre Company the ability to mount productions, including Broadway musicals, which were a technical and financial impossibility in its 450-seat Granville Island Stage. With the opening of the Stanley Theatre the Arts Club Theatre Company experienced a sustained creative and financial boom that led it to surpass the attendance and stature of the venerable Vancouver Playhouse Theatre Company to become, arguably, the city's premier theatre company. The financial resources that the larger venue offered also allowed for the Arts Club to dramatically expand its season from five or six shows a year to twelve to fourteen, and with a much larger number of actors and technicians in the company's employ (Arts Club Theatre Company, 2013). The Arts Club would go on to rebuild the Revue Stage once Vancouver TheatreSports League, which had been the long-term tenant, opened their new Improv Centre and moved out. This allowed the Arts Club to expand to three theatres of varying sizes and produce even more shows each season and further increase its impact on the local performing arts community and the local economy. 
Studio 1398

\begin{tabular}{|c|c|c|c|c|c|c|}
\hline Name & Type & Size & Location & Operator & $\begin{array}{l}\text { New vs } \\
\text { Renovation }\end{array}$ & Source \\
\hline Studio 1398 & $\begin{array}{l}\text { Black box } \\
\text { studio } \\
\text { theatre }\end{array}$ & 96 & Fairview & $\begin{array}{l}\text { Playwrights } \\
\text { Theatre Centre }\end{array}$ & New & $\begin{array}{l}\text { (Granville Island } \\
\text { Cultural Society, 2013) }\end{array}$ \\
\hline
\end{tabular}

Plate 41. Studio 1398, Exterior

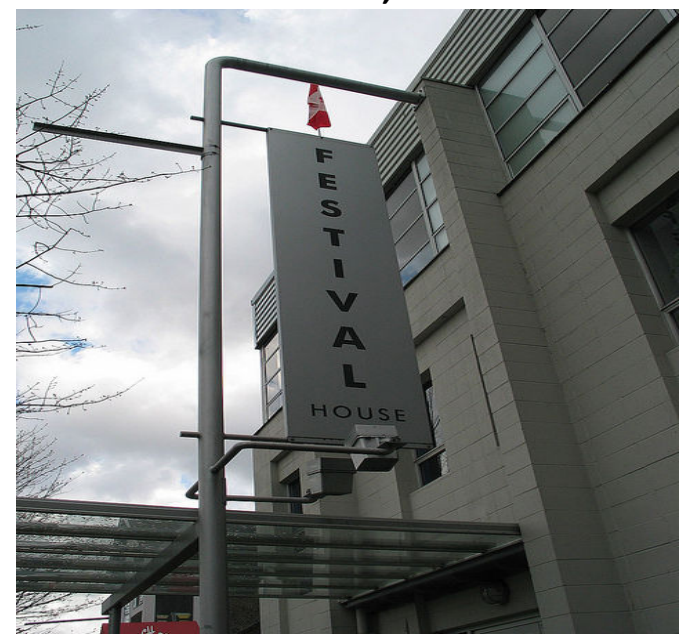

(Granville Island Cultural Society, 2003)
Plate 42. Studio 1398, Interior

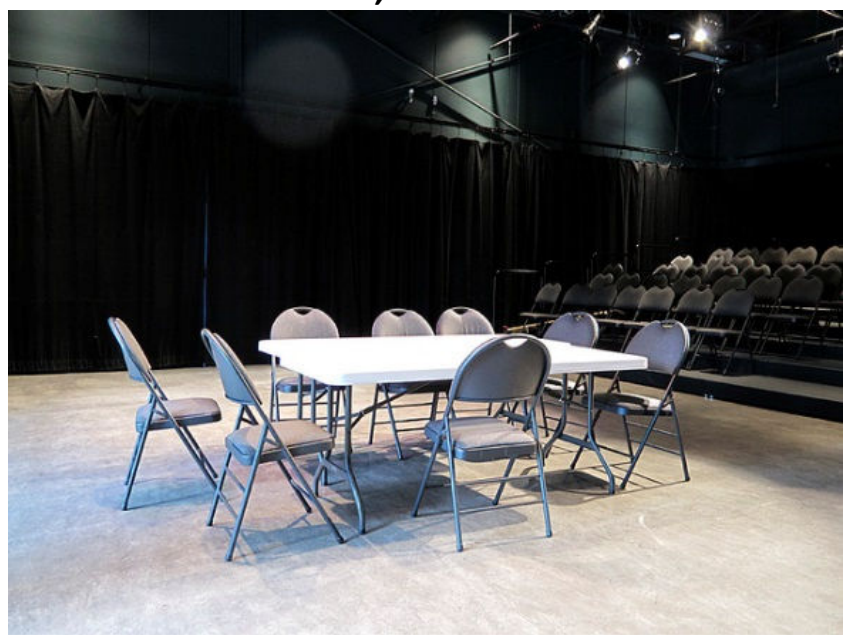

(Granville Island Cultural Society, 2011)

\section{Venue Description}

Studio 1398 is a purpose-built 96-seat incubator performing arts venue located on Granville Island in the Fairview neighbourhood of Vancouver. The small, versatile venue is located on the top floor of a cultural facility called Festival House, which houses the Playwrights Theatre Centre, the Granville Island Cultural Society, as well as other cultural administrative functions for Granville Island including the Buskers Registration Office (Granville Island Cultural Society, 2013). The building was built in 2001 and Studio 1398 (formerly Playwrights Theatre Centre Studio) is in regular use as a rental venue. The venue functions as an incubator performing arts venue by offering some of the lowest rents in the city; as little as $\$ 1,040$ for exclusive use of the space for a week (Studio 1398, 2011). By being located on Granville Island, Studio 1398 joins the Granville Island Stage, Revue Stage, Improv Centre, Performance Works, the Waterfront Theatre, and Carousel Theatre as the Island's performing arts destinations, which attract customers to the restaurants and shops and helps give the Island a sense of place. 


\section{Studio 16}

\begin{tabular}{|c|c|c|c|c|c|c|}
\hline Name & Type & Size & Location & Operator & $\begin{array}{l}\text { New vs } \\
\text { Renovation }\end{array}$ & Source \\
\hline Studio 16 & $\begin{array}{l}\text { Black box } \\
\text { studio } \\
\text { theatre }\end{array}$ & 74 & Fairview & $\begin{array}{l}\text { Centre Culturel } \\
\text { Francophonie } \\
\text { de Vancouver }\end{array}$ & New & $\begin{array}{l}\text { (Centre Culturel } \\
\text { Francophonie de } \\
\text { Vancouver, 2013) }\end{array}$ \\
\hline
\end{tabular}

Plate 43. Studio 16, Exterior

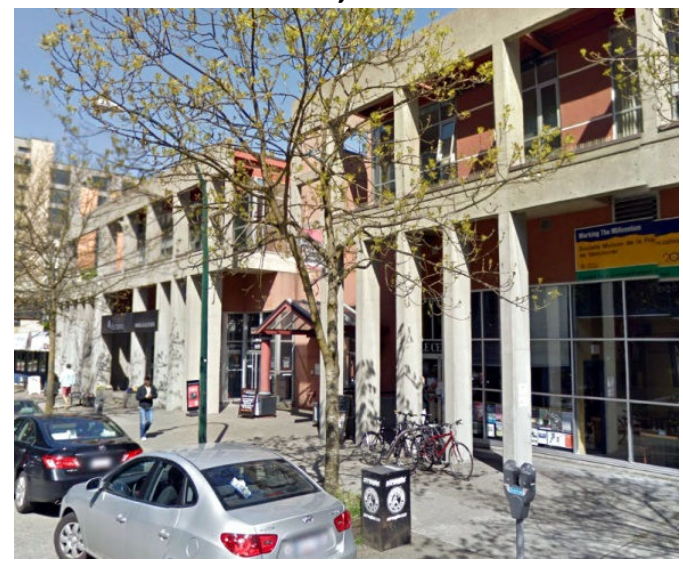

(Google, 2013)

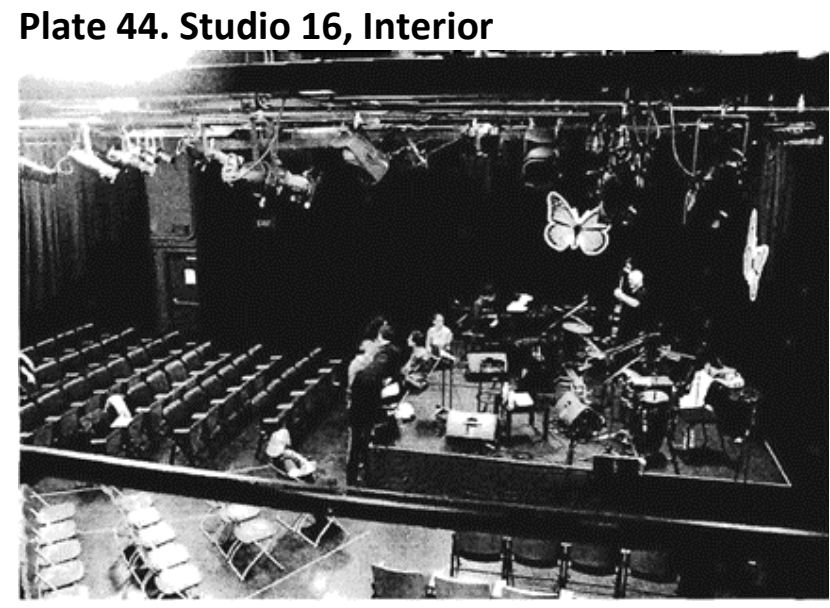

(Metro Vancouver Arts and Culture, 2011)

\section{Venue Description}

Studio 16 is a 74-seat purpose-built black box studio theatre located in the Centre Culturel Francophonie de Vancouver in the Fairview neighbourhood of Vancouver. The venue and Centre were built in 1975 with a mandate of presenting and promoting French culture and as a result, all performances must occur exclusively in French (Le Centre culturel francophone de Vancouver, no date). The Centre also includes classroom space, meeting spaces, and a café, and it is located just off of Granville Street in the 'gallery row' section of the South Granville area. The venue is a flexible black box space that functions as an incubator for French language performing arts and it frequently hosts concerts and plays. 


\section{Studio 58}

\begin{tabular}{|c|c|c|c|c|c|c|}
\hline Name & Type & Size & Location & Operator & $\begin{array}{l}\text { New vs } \\
\text { Renovation }\end{array}$ & Source \\
\hline Studio 58 & $\begin{array}{l}\text { Black box } \\
\text { studio } \\
\text { theatre }\end{array}$ & 120 & Oakridge & $\begin{array}{l}\text { Langara } \\
\text { University } \\
\text { College }\end{array}$ & New & $\begin{array}{l}\text { (Langara } \\
\text { University } \\
\text { College, 2013) }\end{array}$ \\
\hline
\end{tabular}

Plate 45. Langara University College, Exterior

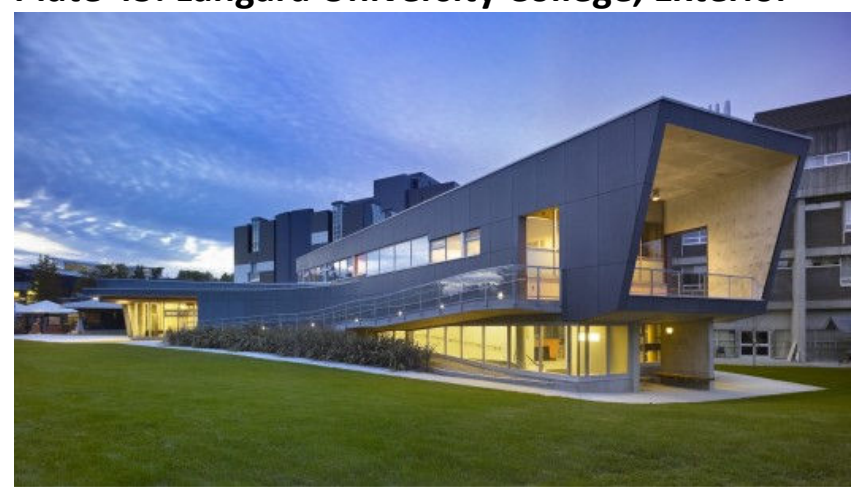

(Gil, 2011)

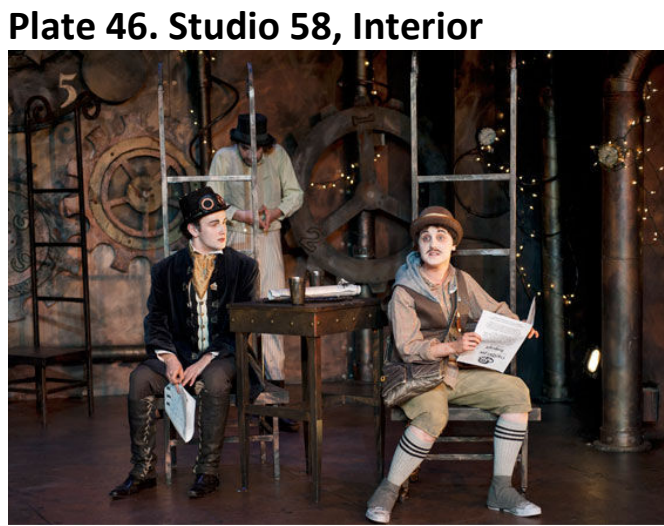

(Cooper, 2011)

\section{Venue Description}

Studio 58 is a 120-seat black box performing arts venue located at Lanagara University College in the Oakridge neighbourhood of Vancouver. The college's theatre school shares its name with the theatre and the space is used throughout the academic year for training, rehearsal, and performances. While the size and configuration of Studio 58 technically classify it as an incubator performing art venue, due to its use as part of the an academic program, the theatre is not available for rent. Despite this, the venue unquestionably acts as an incubator for talent and students both perform and produce the shows that are mounted, including designing and building the sets and costumes. The theatre itself is buried in the basement of the older part of the Langara campus and it lacks the visibility and street presence of the school's new buildings. In time, the original campus build will be redeveloped to make more efficient use of the school's limited land supply and accommodate growing enrollment. At such time, Studio 58 will likely have moved into new purpose-built facilities which will have street presence and potential for programming as a rental venue outside of the academic year. 
The Centre in Vancouver for Performing Arts

\begin{tabular}{|c|c|c|c|c|c|c|}
\hline Name & Type & Size & Location & Operator & $\begin{array}{l}\text { New vs } \\
\text { Renovation }\end{array}$ & Source \\
\hline $\begin{array}{l}\text { The Centre in } \\
\text { Vancouver for } \\
\text { Performing Arts }\end{array}$ & $\begin{array}{l}\text { Proscenium } \\
\text { stage } \\
\text { theatre }\end{array}$ & 1,836 & Downtown & $\begin{array}{l}\text { The Centre in } \\
\text { Vancouver for } \\
\text { Performing Arts }\end{array}$ & New & $\begin{array}{l}\text { (The Centre in } \\
\text { Vancouver for } \\
\text { Performing } \\
\text { Arts, 2007) }\end{array}$ \\
\hline
\end{tabular}

Plate 47. The Centre in Vancouver for Performing Arts, Exterior

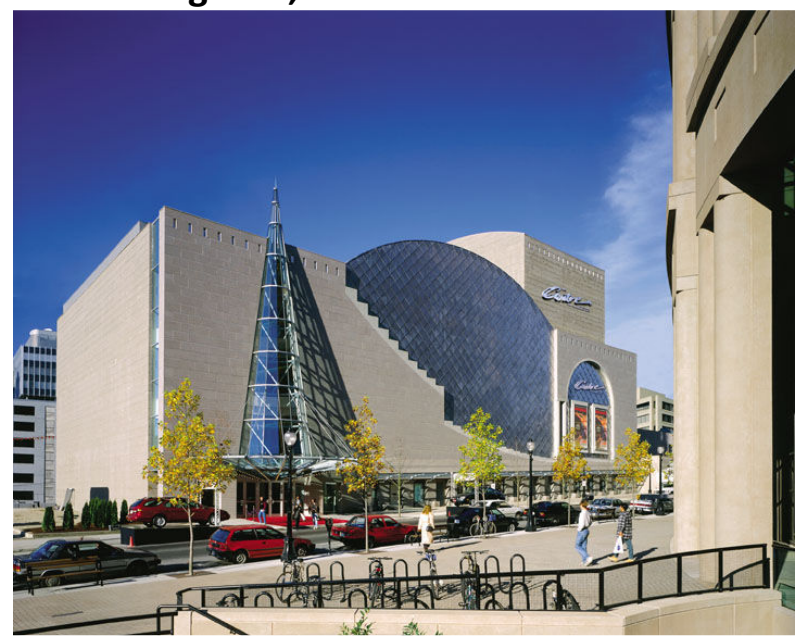

(The Centre in Vancouver, 2007)
Plate 48. The Centre in Vancouver for Performing Arts, Interior

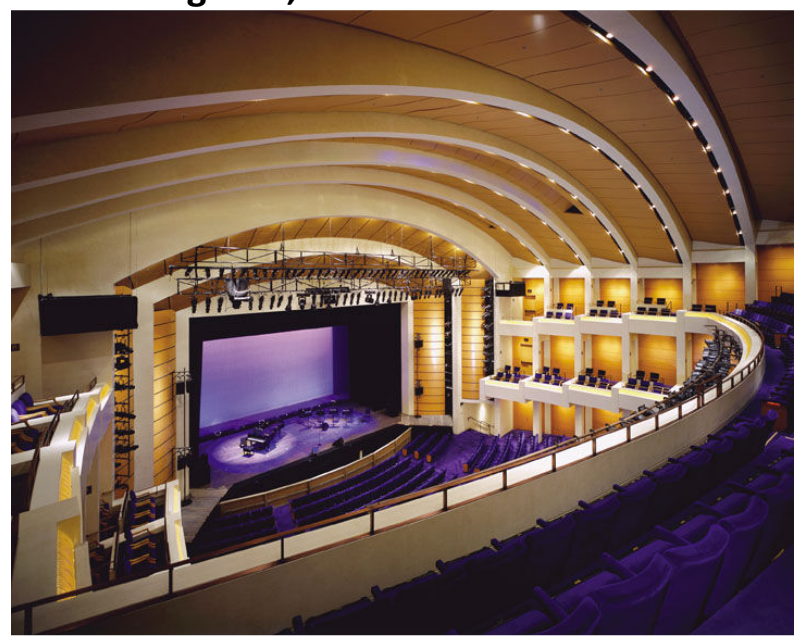

(The Centre in Vancouver, 2007)

\section{Project Description}

The Centre in Vancouver for the Performing Arts is a large, purpose-built 1,836-seat performing arts venue located in downtown Vancouver. The facility was built in 1995 and designed for Broadway musicals, opera, ballet, and concerts. It has three levels of seating, including two balconies, and a large proscenium stage with a fly tower for large sets. The venue is located close to the Queen Elizabeth Theatre and the Vancouver Playhouse, creating a node of cultural activity that helps support nearby restaurants and businesses. The venue is available for rent but the very large size and technical requirements of running the facility put it out of reach for most local companies and it almost exclusively presents touring shows or concerts. 
The Cultch Historic Theatre

\begin{tabular}{|l|l|l|l|l|l|l|}
\hline Name & Type & Size & Location & Operator & $\begin{array}{l}\text { New vs } \\
\text { Renovation }\end{array}$ & Source \\
\cline { 1 - 4 } $\begin{array}{l}\text { The Cultch } \\
\text { Historic Theatre }\end{array}$ & $\begin{array}{l}\text { Proscenium } \\
\text { Stage } \\
\text { theatre }\end{array}$ & 195 & $\begin{array}{l}\text { Grandview- } \\
\text { Woodland }\end{array}$ & $\begin{array}{l}\text { The Vancouver } \\
\text { East Cultural } \\
\text { Centre }\end{array}$ & Renovation & $\begin{array}{l}\text { (The Vancouver } \\
\text { East Cultural } \\
\text { Centre, 2013) }\end{array}$ \\
\hline
\end{tabular}

Plate 49. The Cultch Historic Theatre, Exterior

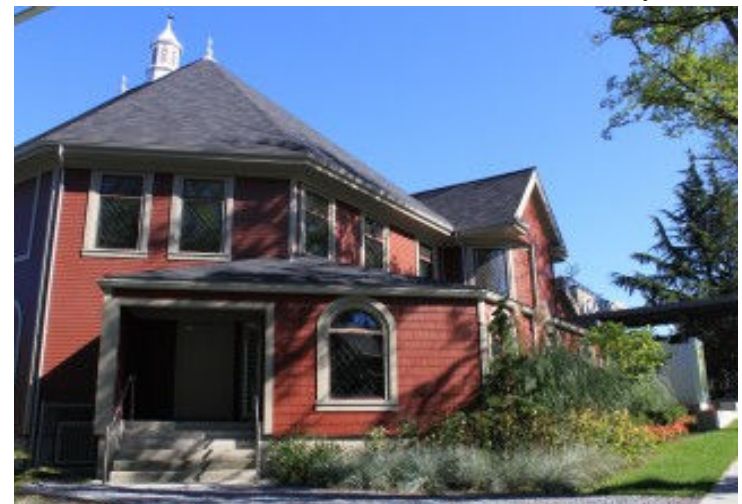

(The Vancouver East Cultural Centre, 2011)
Plate 50. The Cultch Historic Theatre, Interior

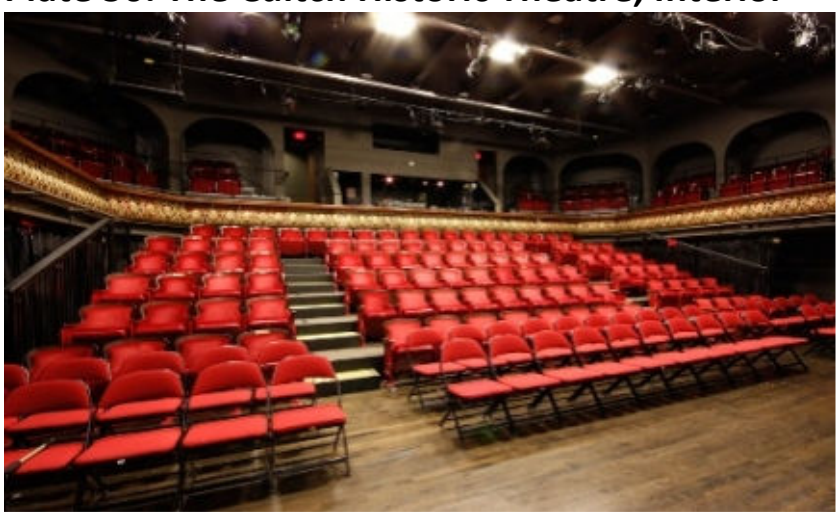

(Stagecoach Theatre Arts Schools Canada, 2011)

\section{Venue Description}

The Vancouver East Cultural Centre (The Cultch) Historic Stage is a 195-seat proscenium stage performing arts venue located in the Grandview-Woodland neighbourhood of Vancouver. The theatre was created through an extensive renovation in 1973 that transformed a former church - which itself was established in a renovated mansion - into a live performing arts venue. In 2009-2011 the theatre was renovated again to improve the washrooms, production equipment, air handling, sound insulation, and seismic stability of the theatre and it became the first performing arts venue in Vancouver to achieve LEED (Leadership in Energy and Environment Design) certification from the Canada Green Building Council (The Vancouver East Cultural Centre, 2011). The Cultch facility also includes a house, which serves as office space, and the new VanCity Culture Lab; a black box studio theatre that shares a common lobby, box office, bar, and backstage areas. The Cultch Historic Stage does not necessary function as an incubator performing arts venue due to its size and the full season of programming that it receives. It is a rental venue and regularly it hosts short-run theatre productions, concerts, and dance. 
The VanCity Culture Lab

\begin{tabular}{|c|c|c|c|c|c|c|}
\hline Name & Type & Size & Location & Operator & $\begin{array}{l}\text { New vs } \\
\text { Renovation }\end{array}$ & Source \\
\hline $\begin{array}{l}\text { The VanCity } \\
\text { Culture Lab }\end{array}$ & $\begin{array}{l}\text { Black box } \\
\text { studio } \\
\text { theatre }\end{array}$ & 74 & $\begin{array}{l}\text { Grandview- } \\
\text { Woodland }\end{array}$ & $\begin{array}{l}\text { The Vancouver } \\
\text { East Cultural } \\
\text { Centre }\end{array}$ & New & $\begin{array}{l}\text { (The } \\
\text { Vancouver } \\
\text { East Cultural } \\
\text { Centre, 2013) }\end{array}$ \\
\hline
\end{tabular}

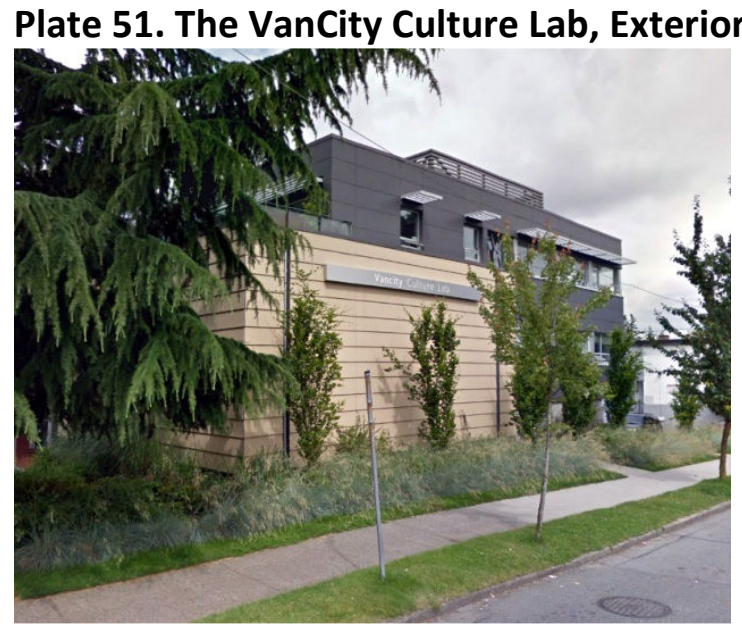

(Google, 2013)

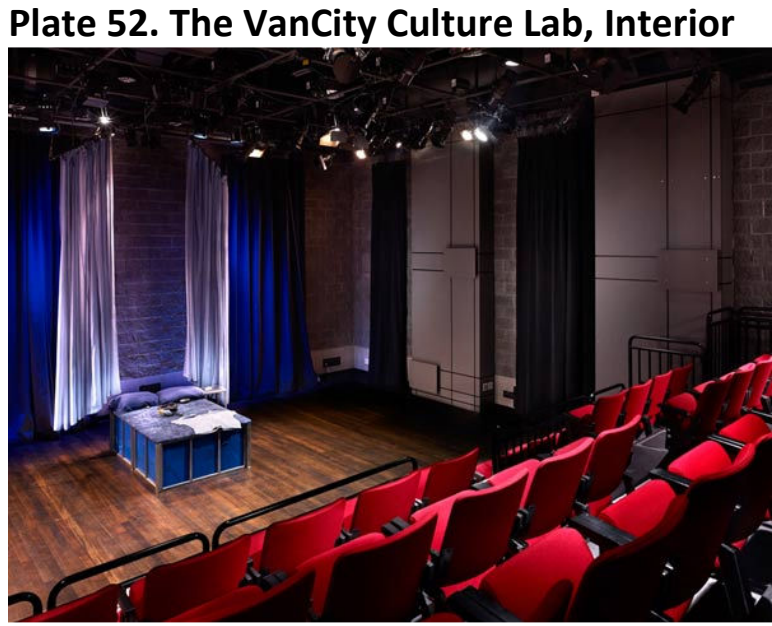

(The Vancouver East Cultural Centre, 2011)

\section{Project Description}

The VanCity Culture Lab is a purpose-built 74-seat black box incubator performing arts space that is part of the Vancouver East Cultural Centre's (The Cultch) facility in the GrandviewWoodland neighbourhood of Vancouver. The venue was built in 2010 as part of large-scale renovation of The Cultch. The VanCity Culture Lab also includes office space, larger back-stage areas, and an improved entry lobby, bar, and gallery. The venue has a sprung floor, which is preferable for dance, and it can easily accommodate theatre, concerts, and spoken word. The combination of intimate audience chamber and the shared resources of the larger Cutch Historic Theatre make the VanCity Culture Lab an unusual incubator performing arts venue. The combined audience drawing power of The Cultch Historic Theatre and the VanCity Culture Lab play an important role in the vitality of the nearby Commercial Drive retail area and between the two theatres, and the nearby Havana Theatre, together can attract upwards of 300 theatre patrons to local restaurants and businesses before or after their performances. 
The Improv Centre

\begin{tabular}{|c|c|c|c|c|c|c|}
\hline Name & Type & Size & Location & Operator & $\begin{array}{l}\text { New vs } \\
\text { Renovation }\end{array}$ & Source \\
\hline $\begin{array}{l}\text { The Improv } \\
\text { Centre }\end{array}$ & $\begin{array}{l}\text { Proscenium } \\
\text { stage theatre }\end{array}$ & 186 & $\begin{array}{l}\text { Granville } \\
\text { Island }\end{array}$ & $\begin{array}{l}\text { Vancouver } \\
\text { Theatresports } \\
\text { League }\end{array}$ & Renovation & $\begin{array}{l}\text { (Vancouver } \\
\text { Theatresports } \\
\text { League, 2013) }\end{array}$ \\
\hline
\end{tabular}

Plate 53. The Improv Centre, Exterior

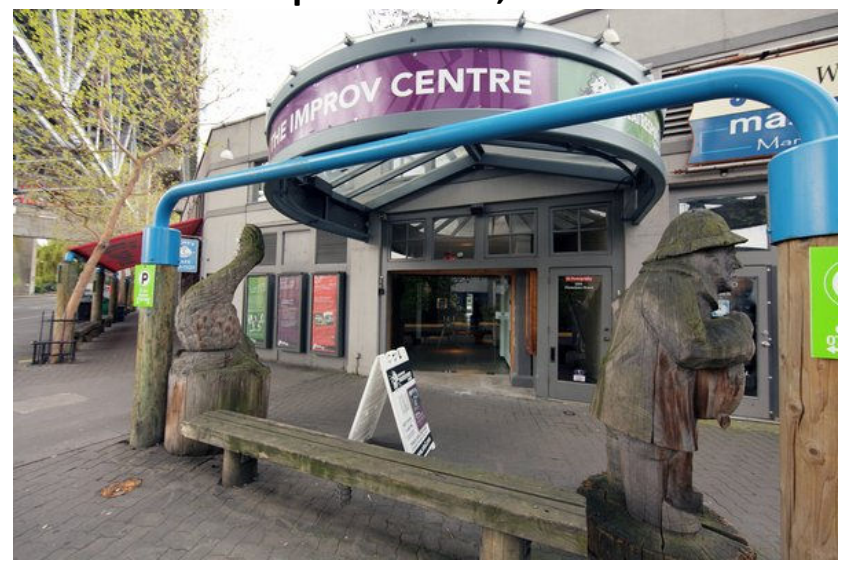

(Granville Island Community and Business Improvement Association, 2013)
Plate 54. The Improv Centre, Interior

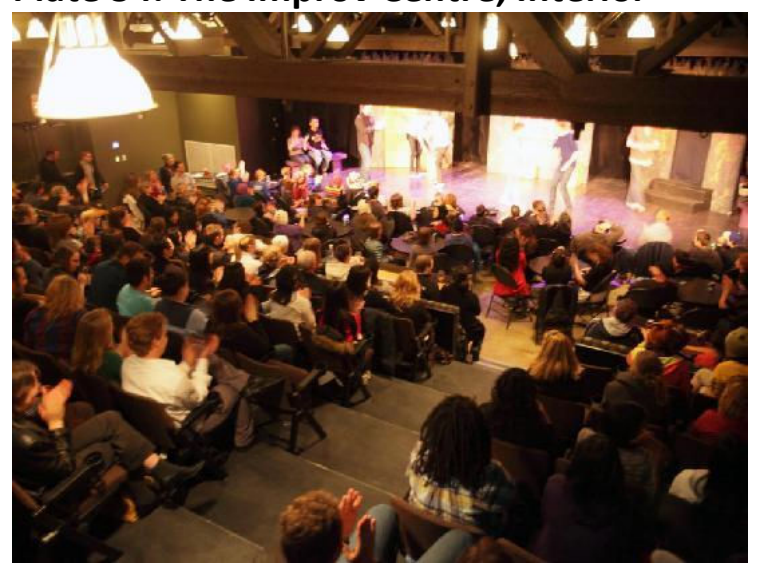

(Granville Island Community and Business Improvement Association, 2013)

\section{Project Description}

The 186-seat Improv Centre is the permanent home of the Vancouver Theatresports League; a professional improvised comedy troupe. The live performance venue has a raised proscenium stage, state of the art lighting and sound, and a combination of tiered theatre seats and cabaret table and chairs (Vancouver Theatresports League, 2013). The Improve Centre was created in 2010 through the renovation of spaces that previously housed a luxury yacht sales office and a model train and ship museum. The building was originally built as an industrial workshop during the 1920s and 1930s when Granville Island was a centre of industry known as Industrial Island (Granville Island Community and Business Improvement Association, 2013).

Vancouver Theatresports League was founded in 1980 and popularized the competitive improvised comedy genre of live theatre (Vancouver Theatresports League, 2013). The troupe was first based out of the Back Alley Theatre in downtown Vancouver and then moved to the Arts Club Theatre Company's Revue Stage on Granville Island in 1998 (Vancouver Theatresports League, 2013). This arrangement was successful in that it provided TheatreSports with a stable 
venue at a low cost, but the concession sales from the bar in the lobby went to the Arts Club and this limited TheatreSports' revenue and made finding a permanent venue of their own a top priority. In late 2008 a building became available on Granville Island and using its own savings, a significant grant from Federal Government, and an affordable long-term loan from VanCity Savings and Credit Union, Vancouver TheatreSports League was able to secure a longterm lease and undertake a million-dollar renovation to turn the space into an intimate venue for comedy and theatre (VanCity, 2010) (Vancouver Theatresports League, 2013). Of particular importance for TheatreSports in its renovation of the Improv Centre was to ensure that there was a bar and concession.

\section{Further Discussion}

Vancouver TheatreSports League's Improv Centre is a model for how a state of the art theatre can be created inside of an existing building. The industrial character of Granville Island's building was emphasized in the renovation, and from the street the exterior looks unchanged. This is important because a large part of the draw of Granville Island is the industrial aesthetic and authentic built form. For the Improv Centre to have been possible, a \$500,000 grant needed to be secured from the Federal Government as part of the economic stimulus package that was introduced in the wake of the Great Recession. The long track record, large attendance, and cash in hand all made Vancouver TheatreSports League a sound candidate for the grant and the loan from VanCity Credit Union. In all likelihood, the proponents who would respond to a tenant call to operate one of the proposed incubator neighbrouhood performing arts venues would not have the track record or resources of TheatreSports. For this reason the City would have to take on the construction of the theatre and its fit out so that it would be ready to go as soon as an operator was selected. The operator would still be responsible for fitting out the adjoining commercial retail space with their own resources. 
The Vancouver Playhouse

\begin{tabular}{|c|c|c|c|c|c|c|}
\hline Name & Type & Size & Location & Operator & $\begin{array}{l}\text { New vs } \\
\text { Renovation }\end{array}$ & Source \\
\hline $\begin{array}{l}\text { The } \\
\text { Vancouver } \\
\text { Playhouse }\end{array}$ & $\begin{array}{l}\text { Proscenium } \\
\text { stage theatre }\end{array}$ & 668 & Downtown & $\begin{array}{l}\text { Civic Theatres } \\
\text { (City of } \\
\text { Vancouver) }\end{array}$ & $\begin{array}{l}\text { New (with } \\
\text { renovations) }\end{array}$ & $\begin{array}{l}\text { (City of } \\
\text { Vancouver, } \\
2013 \text { ) }\end{array}$ \\
\hline
\end{tabular}

Plate 55. The Vancouver Playhouse,

Exterior

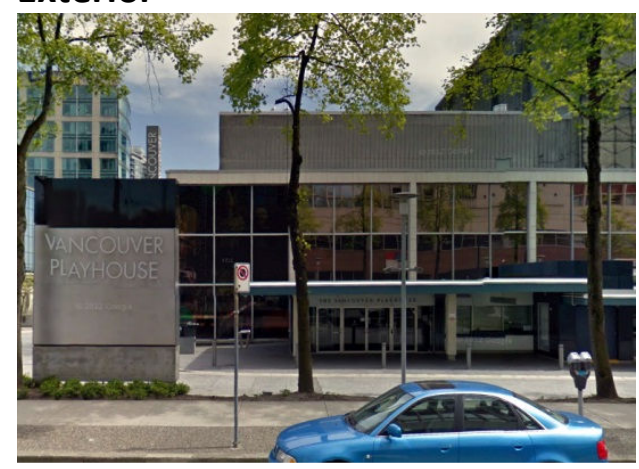

(Google, 2013)
Plate 56. The Vancouver Playhouse, Interior

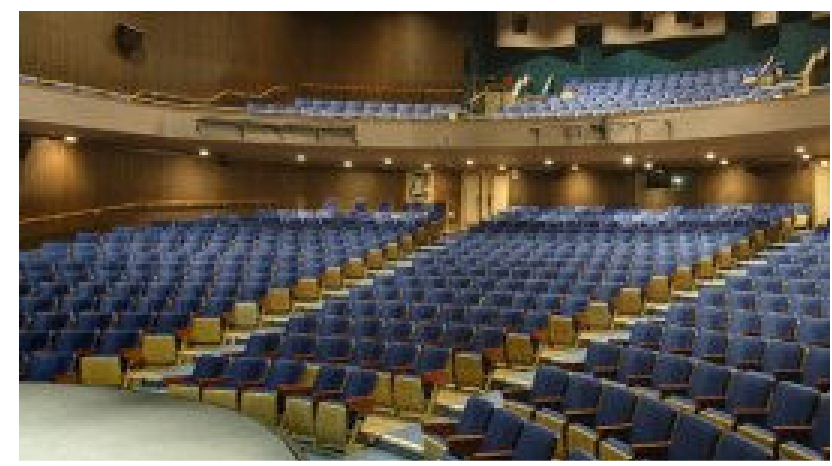

(City of Vancouver, 2013)

\section{Project Description}

The Vancouver Playhouse is a purpose-built 668-seat performing arts venue located in downtown Vancouver. It is part of a larger cultural precinct that includes the Queen Elizabeth Theatre. Both are owned and operated by the City of Vancouver through its Civic Theatres division. Until the Vancouver Playhouse Theatre Company ceased operations in 2012, it was the resident performing arts tenant in the venue and it continues to regularly host concerts and public events and lecture series. The facility was built in 1959-1960 and it embodies the midcentury modern style of the time. Architecturally unsympathetic renovations were undertaken in 1985-1986 in anticipation for the Expo 86 World Fair and the renovations leading up to the 2010 Vancouver Winter Olympic Games restored much of the original character while upgrading facility (City of Vancouver, 2013). 
The Vogue Theatre

\begin{tabular}{|c|c|c|c|c|c|c|}
\hline Name & Type & Size & Location & Operator & $\begin{array}{l}\text { New vs } \\
\text { Renovation }\end{array}$ & Source \\
\hline $\begin{array}{l}\text { The Vogue } \\
\text { Theatre }\end{array}$ & $\begin{array}{l}\text { Proscenium } \\
\text { stage concert } \\
\text { hall }\end{array}$ & 1,114 & Downtown & $\begin{array}{l}\text { The Vogue } \\
\text { Theatre }\end{array}$ & New & $\begin{array}{l}\text { (The Vogue } \\
\text { Theatre, } \\
\text { 2010) }\end{array}$ \\
\hline
\end{tabular}

Plate 57. The Vogue Theatre, Exterior

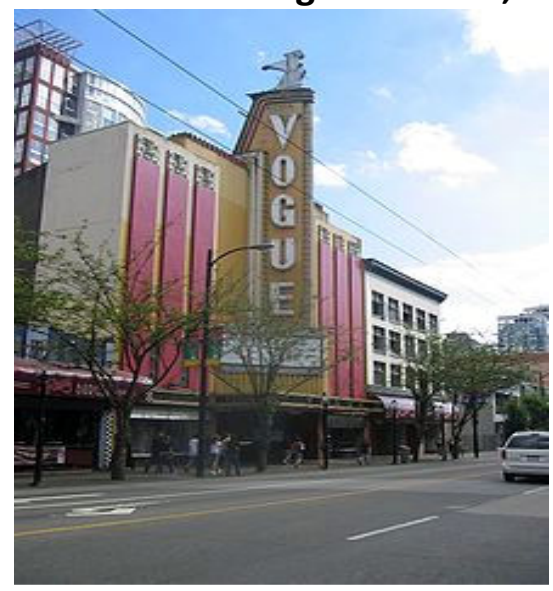

(Arnold C, 2006)
Plate 58. The Vogue Theatre, Interior

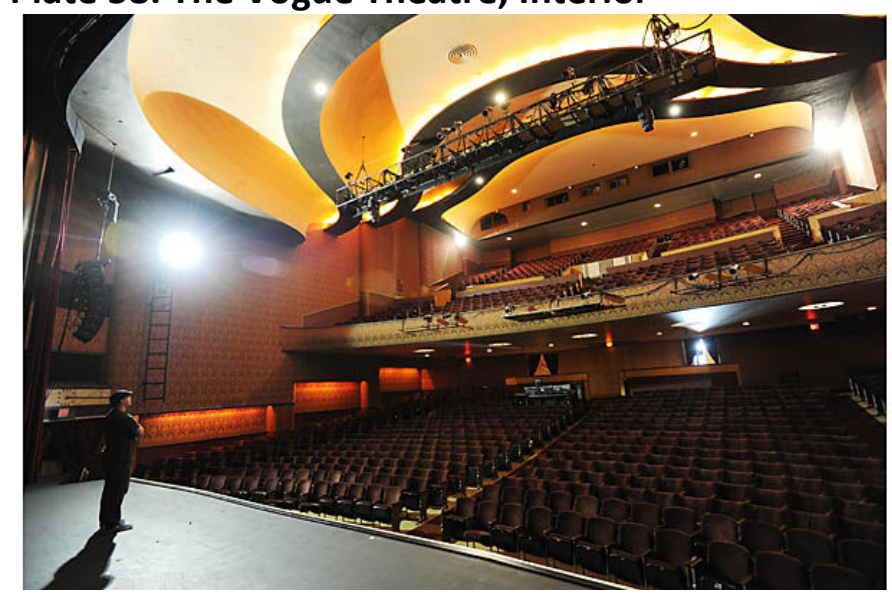

(Payne, 2010)

\section{Project Description}

The Vogue Theatre is a purpose-built 1,114-seat proscenium stage performing arts venue in downtown Vancouver. The venue was built in 1941 in the streamlined Art Deco style of the era and is a registered national historic site (Parks Canada, 2006). It underwent a significant interior and exterior renovation in 2009-2010 and has reopened with its Art Deco aesthetics on full display, including a refurbished neon sign on Granville Street (The Vogue Theatre, 2010). It is primarily a live music venue, however it also a functional cinema and it is used as the gala venue for the Vancouver International Film Festival. The Vogue could be used for theatre, opera, and dance, but it does not have a fly tower nor the extensive backstage areas common to most large theatres (The Vogue Theatre, 2010). 
The Waterfront Theatre

\begin{tabular}{|c|c|c|c|c|c|c|}
\hline Name & Type & Size & Location & Operator & $\begin{array}{l}\text { New vs } \\
\text { Renovation }\end{array}$ & Source \\
\hline $\begin{array}{l}\text { Waterfront } \\
\text { Theatre }\end{array}$ & $\begin{array}{l}\text { Proscenium } \\
\text { stage theatre }\end{array}$ & 224 & Fairview & $\begin{array}{l}\text { Granville } \\
\text { Island } \\
\text { Cultural } \\
\text { Society }\end{array}$ & Renovation & $\begin{array}{l}\text { (Granville Island } \\
\text { Cultural Society, } \\
\text { No date) }\end{array}$ \\
\hline
\end{tabular}

Plate 59. The Waterfront Theatre, Exterior

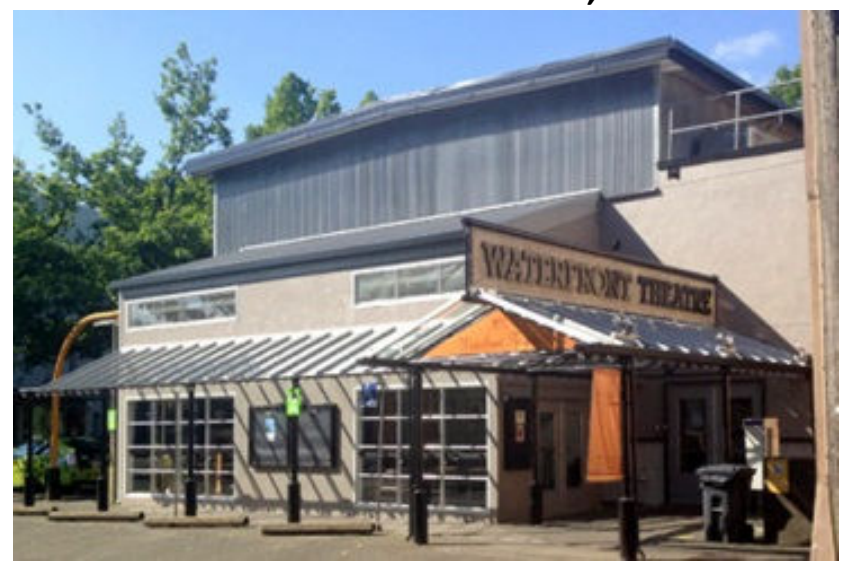

(Granville Island Cultural Society, no date)
Plate 60. The Waterfront Theatre, Interior

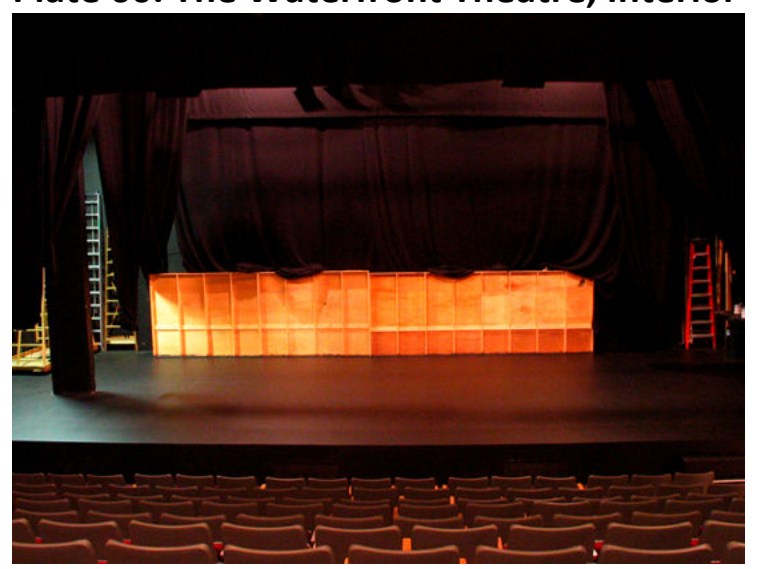

(Granville Island Cultural Society, no date)

\section{Project Description}

The Waterfront Theatre is a 224-seat proscenium stage performing arts venue located on

Granville Island in the Fairview neighbourhood of the City of Vancouver. The venue is housed in a renovated machine shop that was built in the 1920s when Granville Island was known as Industrial Island. The mid-sized venue accommodates theatre, concerts, dance, and comedy. By being located on Granville Island, the Waterfront Theatre joins the Granville Island Stage, Revue Stage, Improv Centre, Performance Works, Studio 1398, and the Carousel Theatre as the Island's performing arts destinations, which attract customers to the restaurants and shops and helps give the Island a sense of place. 


\section{York Theatre}

\begin{tabular}{|c|c|c|c|c|c|c|}
\hline Name & Type & Size & Location & Operator & $\begin{array}{l}\text { New vs } \\
\text { Renovation }\end{array}$ & Source \\
\hline York Theatre & $\begin{array}{l}\text { Proscenium } \\
\text { stage theatre }\end{array}$ & 350 & $\begin{array}{l}\text { Grandview- } \\
\text { Woodlands }\end{array}$ & $\begin{array}{l}\text { Vancouver } \\
\text { East Cultural } \\
\text { Centre }\end{array}$ & Renovation & $\begin{array}{l}\text { (The } \\
\text { Vancouver } \\
\text { East Cultural } \\
\text { Centre, 2013) }\end{array}$ \\
\hline
\end{tabular}

Plate 61. York Theatre in 2013

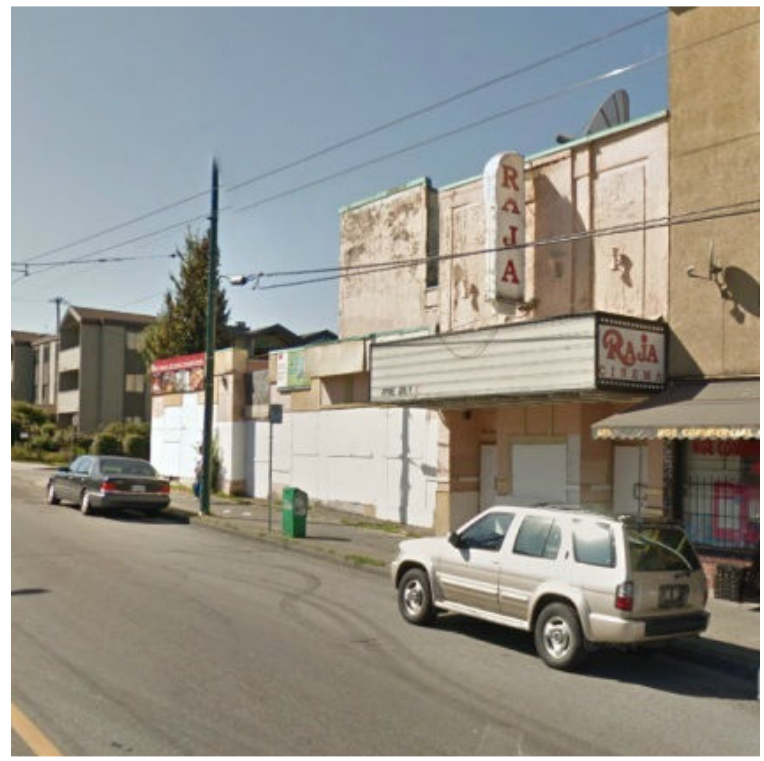

(Google, 2013)

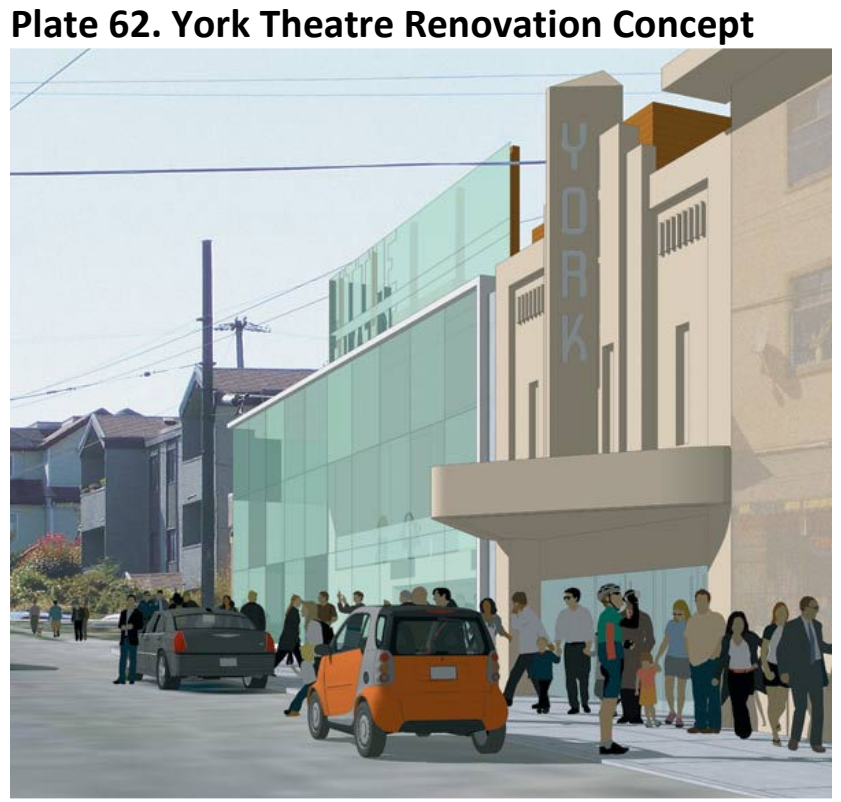

(The Vancouver East Cultural Centre, 2013)

\section{Project Description}

The York Theatre revitalization project will renovate a dilapidated 100-year old neighbourhood theatre in east Vancouver into a modern 350-seat live theatre and performing arts venue, complete with balcony and fly tower. The theatre is located at 639 Commercial Drive (at East Georgia Street) in the heart of the Grandview-Woodlands neighbourhood, just north of the bustling Commercial Drive mixed-use high street.

The $\$ 12$ million dollar renovation is being undertaken by The Vancouver East Cultural Centre (The Cultch) and Henriquez Partners Architects, in partnership with Wall Financial Corporation. The Cultch is celebrating its $40^{\text {th }}$ anniversary in 2013 , and has established itself as one of Vancouver's most innovative and vital theatre companies (The Vancouver East Cultural Centre, 2013). Henriquez Partners Architects is a socially-engaged architecture practice with a portfolio 
of culturally-anchored mixed-use buildings (Henriquez Partners Architects, 2013). Wall Financial Corporation is a publicly traded Vancouver-based real estate development company with an extensive track record of partnering to create performing arts venues as part of its high-rise residential and mixed-use developments (The Vancouver East Cultural Centre, 2013). Upon completion, the York Theatre will be operated by The Cultch and function primarily as a rental venue as well as programming from its eclectic annual season of live theatre, concerts, and dance (The Vancouver East Cultural Centre, 2013).

The York Theatre was built between 1912 and 1913 as The Alcazar Theatre. It was a 600-seat live theatre and music venue built in the contemporary Edwardian architectural style, and upon construction it was the only theatre on Vancouver's east side with a balcony, fly tower, proscenium stage, and an orchestra pit (Heritage Vancouver Society, 2008). Throughout its century of life, it has been renovated to remain culturally relevant and economically viable (Heritage Vancouver Society, 2008). The Alcazar was renamed to 'The York Theatre' when it received an ambitious Art Deco makeover in the early 1940s and became home to the groundbreaking Vancouver Little Theatre Association. In the 1960s it received architecturally unsympathetic exterior alterations and additions that obscured much of the earlier exterior and interior detail (Heritage Vancouver Society, 2008). Renamed the New York Theatre, during the 1980 s it was an in-demand inexpensive venue with a large capacity for upcoming punk, heavy metal, and grunge bands like Metallica, Nirvana, Marilyn Manson, Sonic Youth, The Dead Kennedys, GWAR, and others (Setlist.fm, No date) (Heritage Vancouver Society, 2008). A final conversion back to cinema occurred in the late 1990s when stucco exterior repair work, minimal interior maintenance, rooftop satellite dish, and a name change to The Raja allowed the deteriorating theatre to live on for another decade as a Bollywood movie theatre before the property was purchased by a developer that permanently closed the theatre pending demolition. The property was later re-sold to the Wall Financial Corporation once a deal to save the theatre had been brokered.

With the theatre of demolition looming for many years, an engaged group of citizens and members of the city's arts and theatre community founded the 'Save the York Society' and 
succeeded at calling attention to the venue's future potential and imminent risk of demise. With the assistance of Jim Green and Associates and the Vancouver Heritage Society, The Cultch, the City of Vancouver, and Wall Financial Corporation agreed to work together to save The York and restore it to functionality and use as a live performance venue (Grant, 2009).

A \$12 million dollar Heritage Restoration Agreement (HRA) was drafted that would utilize the sale and transfer of heritage density to cover the hard cost of renovating and restoring the theatre and The Cultch took on responsibility for its maintenance, operation, and programming (The Vancouver East Cultural Centre, 2013). Henriquez Partners Architects developed a preliminary concept plan for the restoration as part of the Heritage Restoration Agreement (see plate 53, below) and Wall Financial Corporation received the right to 'land' the York Theatre's heritage density on its upcoming development through existing density bonusing tools.

\section{Plate 63. Design for the York Theatre restoration}

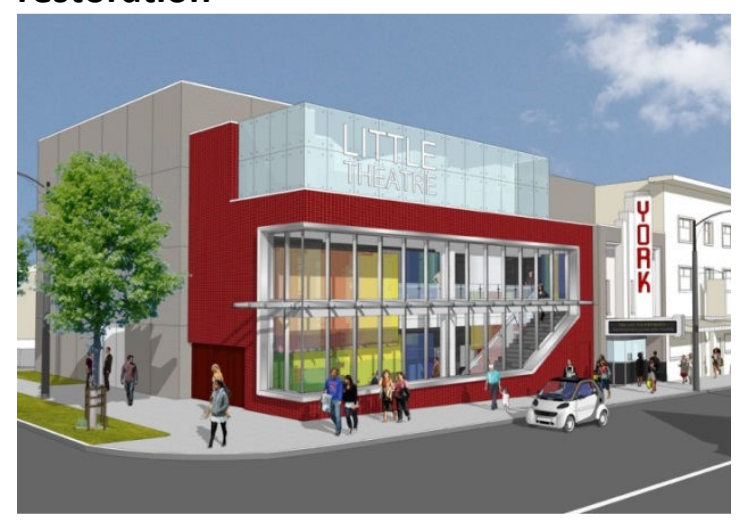

(Henriquez Partners Architects, 2013)

\section{Plate 64. York Theatre Construction progress}

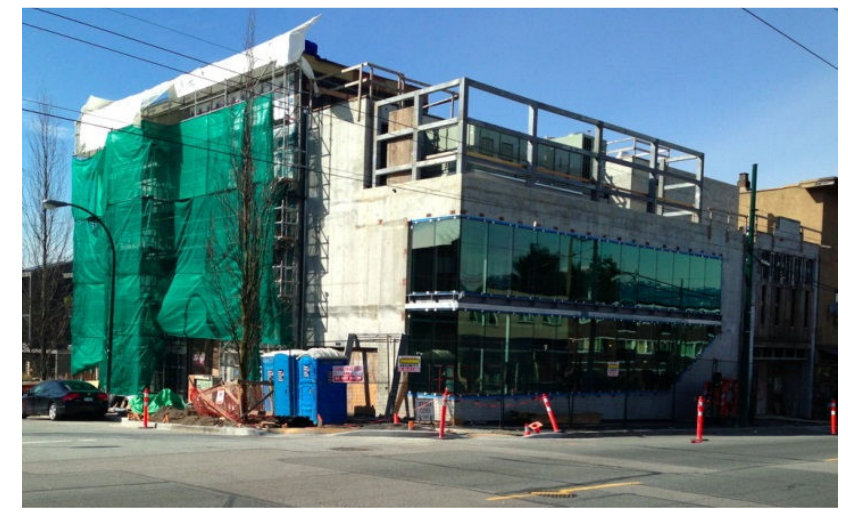

(Crilly, The York Theatre re-development is moving along nicely, 2013)

\section{Further Discussion}

All Heritage Restoration Agreements (HRA) are, by definition, ad-hoc. They are intended to preserve unique examples of built heritage by forging deals that create an attractive enough value proposition in the retention and restoration of the building that its outright demolition becomes ill-considered. For the York Theatre, the HRA that was negotiated between The Cultch, the City, and Wall Financial Corporation trades heritage density from a dilapidated shadow of its former self to recipient sites that will be built out in the years ahead. These will be slightly 
taller and more dense than as-of-right zoning permits due to the 'landing' of the York Theatres heritage density, but this essentially administrative movement of density creates the conditions on the ground that allow a century-old piece of Vancouver's cultural history to come to life again and act as a catalyst for regeneration of the north end of Commercial Drive.

Currently the highly animated continuous street-level retail environment of Commercial Drive ends with the blocks surrounding the intersection of Commercial Drive and Venables. North of this intersection, towards the York Theatre, the street level character of the street changes to that of landscaped or gated setbacks for low- and medium-rise apartment buildings and houses. The block in which the York Theatre is located is shared with a three-storey pre-war apartment building that has retail at grade, including a well-established spaghetti restaurant - Nick's Spaghetti House - that dates back to 1956 (Adam \& Green, 2008). Further north is Hastings Street; one of the city's great, if-underutilized, streets. As the ongoing redevelopment of Hastings Street from the east and west converges on Commercial Drive, the importance and relevance of a revitalized York Theatre will be all the more important. Furthermore, both Hastings and Commercial Drive have frequent high capacity bus service and the latter connects to SkyTrain at Commercial-Broadway Station, placing the York Theatre in the enviable position of being highly accessible to transit.

The value proposition of renovation versus new-construction is many-fold. In addition to further extending the life of the structure and the investment of materials, energy, and wealth in the structure of the building, there is an intangible - but very real - quality to preserving a physical manifestation of an earlier time in the city's history and occupying and enjoying a space in much the same way as others have done for decades - and a century - before.

While the efforts to save the York Theatre were under way, a moratorium was in effect that prohibited new 'donor sites' from entering into heritage restoration agreements that would allow them to sell and transfer their heritage density to the Heritage Density Bank. The Director of Planning, Brent Toderian, had received Council approval to put the moratorium in place out 
of concern that the Heritage Density Bank was acquiring density at a greater rate than it could be sold to developers - the recipient sites - through density bonusing. The price developers pay to purchase heritage density for use in their projects and the amount paid out to donor sites in a heritage restoration agreement are dependent on the amount of density available in the Heritage Density Bank. It was felt that the slow residential market cycle following the Great Recession of $2008 / 9$ was resulted in too much heritage density accumulating in the Heritage Density Bank and too little being paid by the developers when compared with the benefits they received. Moreover, the low price for heritage density was seen to be undermining the favourable land economics of landowners choosing to enter into a heritage restoration agreement. Without a recovery in heritage density prices it was feared that the future of the previously-successful mechanism for saving built heritage through a self-financing density transfer system would be severely jeopardized and there would be a high likelihood that owners of old building stock would choose to demolish and redevelop their properties instead of retaining them in-situ and restoring them using the windfall of the sale of their heritage density.

The temporary moratorium was intended to allow the development industry to recover and draw down on the Heritage Density Bank during the post-recessionary residential construction boom and once prices were stabilized In the decade since the Stanley Theatre, Through an innovative heritage restoration agreement authorized by Vancouver City Council, The Cultch will sell and transfer the York Theatre's heritage density to Wall Financial Corporation for use as a density bonus in upcoming developments. 


\section{BIBLIOGRAPHY}

Adam, E. M., \& Green, B. (2008, 6 15). Nick's Spaghetti House. Retrieved 3 18, 2013, from Viaduct: Travels Through East Vancouver: http://viaducteast.ca/2008/06/15/nicksspaghetti-house/

Alliance for Arts and Culture. (no date). Firehall Arts Centre. Retrieved 3 28, 2013, from Alliance for Arts and Culture: http://www.allianceforarts.com/users/firehall-arts-centre

Ang B. (2009, 10 18). Arts Club Theatre Company Stanley Industrial Alliance Stage. Retrieved 3 19, 2013, from Picasa:

http://picasaweb.google.com/lh/photo/aFbjxZDZWfZvTWBuuae6bA

Arnold C. (2006, 6 7). Vogue Theatre. Vancouver, BC, Canada. Vancouver, British Columbia, Canada. Retrieved 4 14, 2013, from http://en.wikipedia.org/wiki/File:Vogue-thtr.jpg

Arts Club Theatre Company. (2010, 9 27). Revue Stage. Arts Club Theatre Blog. Vancouver, British Columbia, Canada. Retrieved 4 14, 2013, from http://blog.artsclub.com/2010/09/27/culture-days-at-the-arts-club-theatre-company/

Arts Club Theatre Company. (2013). About Us. Retrieved 4 1, 2013, from Arts Club Theatre Company: http://blog.artsclub.com/about-us/

Arts Club Theatre Company. (2013). Company History. Retrieved 3 19, 2013, from Arts Club Theatre Company: http://www.artsclub.com/about/history.htm

Arts Club Theatre Company. (2013). Show Archive. Retrieved 3 19, 2013, from Arts Club Theatre Company: http://www.artsclub.com/about/archives/index.htm

Arts Club Theatre Company. (no date). Granville Island Strage Technical Specifications. Retrieved 4 1, 2013, from Arts Club Theatre Company: http://production.artsclub.com/GI\%20Stage\%20Tech\%20Info/index.htm

Berelowitz, L. (2005). Dream City: Vancouver and the Global Imagination. Vancouver: Douglas and Mclntyre.

Bobanny. (2007, 4 14). Firehall Arts Centre. Vancouver, British Columbia, Canada. Retrieved 41 , 2013, from http://commons.wikimedia.org/wiki/File:Fire_Hall_Arts_Centre.jpg

Boddy, T. (2005, September 20). INSIGHT: Vancouverism vs. Lower Manhattanism: Shaping the High Density City . Retrieved December 2, 2012, from ArchNewsNow.com: http://www.archnewsnow.com/features/Feature177.htm

Burgraeve, D. (2007, 10 17). Les Échos du Pacifique présentant leur spectacle de "Comédies musicales " au Jericho Arts Centre à Vancouver. Les Echos du Pacifique. Vancouver, British Columbia, Canada. Retrieved 4 14, 2013, from http://www3.telus.net/lesechosdupacifique/photos.html

Carousel Theatre for Young People. (2012). Studio Space Rentals on Granville Island. Retrieved 3 31, 2013, from Carousel Theatre for Young People: http://www.carouseltheatre.ca/about-carousel-theatre/studio-rentals/

Centre Culturel Francophonie de Vancouver. (2013). Studio 16. Retrieved 3 38, 2013, from Centre Culturel Francophonie de Vancouver: http://www.vancouverfringe.com/pdfs/Studio16VenueSpecs2012.pdf

City of Vancouver. (2004, 2). Financing Growth: Paying for City facilities to serve a growing population: the role of cty-wide charges on new development. Retrieved 316,2013 , 
from City of Vancouver:

http://former.vancouver.ca/commsvcs/planning/financinggrowth/documents.htm

City of Vancouver. $(2008,5)$. City of Vancouver Cultural Facilities Priority Plan, Final Report.

Retrieved 3 26, 2013, from City of Vancouver:

http://vancouver.ca/files/cov/CulturePlan-Phase1-Facilities-Study.pdf

City of Vancouver. (2008, 6 13). Cultre Plan Implementation - Phase 1 of 2008 - 2023 Cultural

Facilities Priorities Plan. Retrieved 3 30, 2013, from City of Vancouver:

https://vancouver.ca/files/cov/CulturePlan-Phase1-Facilities-Plan.pdf

City of Vancouver. $(2008,1)$. Culture Plan 2008 - 2018. Retrieved 326 , 2013, from City of

Vancouver: http://vancouver.ca/parks-recreation-culture/culture-plan-2008-2018.aspx

City of Vancouver. (2008, June 10). Vancouver EcoDensity Charter: How Density, Design, and Land Use Will Contribute to Environmental Sustainability, Affordability, and Livability. Retrieved December 3, 2012, from City of Vancouver: http://former.vancouver.ca/commsvcs/ecocity/pdf/ecodensity-charter-low.pdf

City of Vancouver. (2009, 9 3). 2008 - Development Cost Levies Status Report on Collection and Expenditure. Retrieved 03 07, 2013, from Financing Growth Documents: http://former.vancouver.ca/commsvcs/planning/financinggrowth/documents.htm

City of Vancouver. (2010, 5 10). CD-1 (462) Bylaw No. 9594 - Policy Report Development and Planning. Retrieved 3 14, 2013, from City of Vancouver Rezoning Centre: http://former.vancouver.ca/commsvcs/planning/rezoning/applications/140w1st/index. htm

City of Vancouver. (2011, May 9). Community Amenity Contributions Through Rezonings. Retrieved November 17, 2012, from City of Vancouver, Community Amenity Contributions: http://former.vancouver.ca/commsvcs/guidelines/C025.pdf

City of Vancouver. (2012, 6 12). 2011 Council Report on Public Benefits Secured Through Approvals of Additional Density. Retrieved 325,2013 , from City of Vancouver: http://former.vancouver.ca/commsvcs/planning/financinggrowth/documents.htm

City of Vancouver. (2012, October 2). Community Amenity Contributions. Retrieved November 15, 2012, from City of Vancouver Home, Property, and Development: http://vancouver.ca/home-property-development/community-amenitycontributions.aspx

City of Vancouver. (2012, 12 20). Cultural Space Leasing Opportunity 140 West 1st Tenant Call. Retrieved 3 17, 2013, from City-Owned Property for Sale or Lease: http://vancouver.ca/files/cov/Cultural-spaces-infosheet-140-west-1st.pdf

City of Vancouver. (2012, 12 20). Cultural Space Tenant Selection: 140 West 1st Avenue. Retrieved 3 17, 2013, from City-owned Properties for Sale and Lease: http://vancouver.ca/doing-business/cultural-space-tenant-selection-140-west-1stavenue.aspx

City of Vancouver. (2012, 5 15). Live Performance Venue Regulatory Review Overview 2011. Retrieved 3 26, 2013, from City of Vancouver: http://vancouver.ca/files/cov/LivePerformanceVenueRegulatoryReviewOverview_2011.pdf

City of Vancouver. (2012, June 11). Major Planning Projects. Retrieved February 18, 2013, from City of Vancouver - Home, Property, Development - Urban Planning, Zoning, and 
Development: https://vancouver.ca/home-property-development/major-planningprojects.aspx

City of Vancouver. (2012, 6 13). Orpheum Annex. Retrieved 3 23, 2013, from Theatres and Performance Spaces: http://vancouver.ca/parks-recreation-culture/rent-the-orpheumannex.aspx

City of Vancouver. (2013). Cambie Corridor Plan. Retrieved 3 5, 2013, from City of Vancouver Home, Property, and Development: http://vancouver.ca/home-propertydevelopment/cambie-corridor-plan.aspx

City of Vancouver. (2013). Central Broadway Corridor Plan. Retrieved 3 5, 2013, from City of Vancouver Home, Property, and Development: http://vancouver.ca/home-propertydevelopment/central-broadway-corridor.aspx

City of Vancouver. (2013). Chiantown Revitalization. Retrieved 3 5, 2013, from City of Vancouver Home, Property, and Development: http://vancouver.ca/home-propertydevelopment/chinatown-revitalization.aspx

City of Vancouver. (2013). Culture Plan Implementation Phase 1 - Cultural Tourism Strategy. Retrieved 3 14, 2013, from City of Vancouver Parks, Recreation, and Culture: http://vancouver.ca/files/cov/CulturePlan-Phase1-Tourism-Strategy.pdf

City of Vancouver. (2013). Downtown East Side Local Area Plan. Retrieved 3 5, 2013, from City of Vancouver Home, Property, and Development: http://vancouver.ca/home-propertydevelopment/dtes-local-area-plan.aspx

City of Vancouver. (2013). Facilities List. Retrieved 3 25, 2013, from City of Vancouver: http://app.vancouver.ca/PerformingArts_Net/Facilitylist.aspx

City of Vancouver. (2013). Grandview-Woodland Community Plan. Retrieved 3 5, 2013, from City of Vancouver Home, Property, and Development: http://vancouver.ca/homeproperty-development/grandview-woodland-community-plan.aspx

City of Vancouver. (2013). Green Buildings. Retrieved 4 5, 2013, from City of Vancouver Greenest City 2020 Action Plan: http://vancouver.ca/green-vancouver/greenbuildings.aspx

City of Vancouver. (2013). Little Mountain Master Plan. Retrieved 3 5, 2013, from City of Vancouver Home, Property, and Development: http://vancouver.ca/home-propertydevelopment/little-mountain.aspx

City of Vancouver. (2013). Marpole Community Plan. Retrieved 3 5, 2013, from City of Vancouver Home, Property, and Development: http://vancouver.ca/home-propertydevelopment/marpole-community-plan.aspx

City of Vancouver. (2013). Mount Pleasant Community Plan. Retrieved 3 5, 2013, from City of Vancouver Home, Property, and Development: http://vancouver.ca/home-propertydevelopment/mount-pleasant-community-plan.aspx

City of Vancouver. (2013). Norquay Village Community Plan. Retrieved 3 5, 2013, from City of Vancouver Home, Property, and Development: http://vancouver.ca/home-propertydevelopment/norquay-village-neighbourhood-centre-plan.aspx

City of Vancouver. (2013). Oakridge Centre Redevelopment. Retrieved 3 5, 2013, from City of Vancouver Home, Property, and Development: http://vancouver.ca/home-propertydevelopment/oakridge-redevelopment.aspx 
City of Vancouver. (2013). Olympic Village. Retrieved 3 5, 2013, from City of Vancouver Home, Property, and Development: http://vancouver.ca/home-propertydevelopment/olympic-village.aspx

City of Vancouver. (2013). Queen Elizabeth Theatre. Retrieved 32 , 2013, from City of Vancouver Parks Recreation and Culture: http://vancouver.ca/parks-recreation-culture/queenelizabeth-theatre.aspx

City of Vancouver. (2013). Southeast False Creek. Retrieved 3 5, 2013, from City of Vancouver Home, Property, and Development: http://vancouver.ca/home-propertydevelopment/southeast-false-creek.aspx

City of Vancouver. (2013). Southeast False Creek Official Development Plan. Retrieved 325 , 2013, from City of Vancouver Rezoning Centre: http://former.vancouver.ca/commsvcs/bylaws/odp/SEFC.pdf

City of Vancouver. (2013). The Orpheum Theatre. Retrieved 25 3, 2013, from City of Vancouver Parks and Recreation - Theatres and Performance Spaces: http://vancouver.ca/parksrecreation-culture/the-orpheum.aspx

City of Vancouver. (2013). Vancouver Playhouse. Retrieved 32 , 2013, from City of Vancouver Parks, Recreation and Culture: http://vancouver.ca/parks-recreation-culture/vancouverplayhouse.aspx

City of Vancouver. (2013). Venue List. Retrieved 3 25, 2013, from City of Vancouver: http://app.vancouver.ca/PerformingArts_Net/Venuelist.aspx

City of Vancouver. (2013). West End Community Plan. Retrieved 3 5, 2013, from City of Vancouver Home, Property, and Development: http://vancouver.ca/home-propertydevelopment/west-end-community-plan.aspx

City of Vancouver. (no date). Norman Rothstein Theatre. Performing Arts Facility Inventory. Vancouver, British Columbia, Canada. Retrieved 4 4, 2013, from https://app.vancouver.ca/PerformingArts_Net/Facilitydetail.aspx?id=42

Cole, Y. (2013, 3 12). Vancouver approves pilot rogram for indoor arts events. Retrieved 314 , 2013, from The Georgia Straight: http://www.straight.com/arts/361126/vancouverapproves-pilot-program-indoor-arts-events

Conference Board of Canada. (2008). Valuing Culture: Measuring and Understanding Canada's Cultural Economy. Conference Board of Canada.

Cooper, E. (2011, 9 28). The Star. Retrieved 4 12, 2013, from 24 Hours: http://vancouver.24hrs.ca/News/local/2011/09/21/18721611.html

Crilly, B. (2013, 03 24). The York Theatre re-development is moving along nicely. SkyscraperPage.com forums. Vancouver, British Columbia, Canada. Retrieved 325 , 2013, from http://forum.skyscraperpage.com/showpost.php?p=6065244\&postcount=3838

Crilly, B. $(2013,4$ 1). Wall Centre False Creek. Vancouver, British Columbia, Canada. Retrieved 4 1, 2013, from http://forum.skyscraperpage.com/showthread.php?t=138106\&page=200

Crystal H. (2009, 4 21). New Revue Stage. Yelp. Vancouver, British Columbia, Canada. Retrieved 4 14, 2014, from http://www.yelp.ca/biz_photos/revue-stagevancouver?select=B7sC_sKCEsguECMiiaOLxw\#B7sC_sKCEsguECMiiaOLxw

Dance Centre. (2001). Contact Us. The Dance Centre. Vancouver, British Columbia, Canada. Retrieved 4 13, 2013, from http://www.thedancecentre.ca/contact 
Faulker, A. (1999). Stanley Theatre. Proscenium Architecture. Vancouver, British Columbia, Canada. Retrieved 4 14, 2013, from http://www.proscenium.ca/images/stanley_web1.jpg

Firehall Arts Centre. (2013). About Us. Retrieved 4 1, 2013, from Firehall Arts Centre: http://firehallartscentre.ca/about-us/

Firehall Arts Centre. (2013). FAC Technical Specifications. Retrieved 327,2013 , from Firehall Arts Centre: http://firehallartscentre.ca/wp/wp-content/uploads/2012/02/FAC-techspecs2012.pdf

Florida, R. (2012). Rise of the Creative Class Revisited. New York: Basic Books.

Foodp. (2012, 5 24). Havanas Patio. Flickr. Vancouver, British Columbia. Retrieved 3 25, 2013, from http://www.flickr.com/photos/68393571@N08/7264313106/

Friends of Jericho Arts Centre Society . (No date). About Jericho Arts Centre. Retrieved 325 , 2013, from Jericho Arts Centre: http://www.jerichoartscentre.com/aboutus.html

Gil, S. (2011, 3 17). Langara Student Union / Teeple Architects in association with IBI/HB Architects . Retrieved 4 12, 2013, from Arch Daily:

http://www.archdaily.com/120688/langara-student-union-teeple-architects-inassociation-with-ibihb-architects/

Google. (2013). Street View. Vancouver, British Columbia, Canada. Retrieved 4 14, 2013, from Maps.google.ca

Grant, P. (2009, 2 2). Vancouver developer has $\$ 12 M$ to save York Theatre. Retrieved 319 , 2013, from CBC News | Arts and Entertainment: http://www.cbc.ca/news/arts/theatre/story/2009/02/02/vancouver-theatre.html

Granville Island Community and Business Improvement Association. (2013). Vancouver Theatre Sports. Granville Island Works. Vancouver, British Columbia, Canada. Retrieved 325 , 2013, from http://granvilleislandworks.com/profile/vancouver-theatresports-league

Granville Island Cultural Society. (2003, 4 2). Festival House. Flickr. Vancouver, British Columbia, Canada. Retrieved 4 12, 2013, from http://www.flickr.com/photos/gics/5916357775/in/photostream

Granville Island Cultural Society. (2011, 7 8). Studio 1398 Interior. Flickr. Vancouver, British Columbia, Canada. Retrieved 4 13, 2013, from http://www.flickr.com/photos/gics/5916917294/in/photostream

Granville Island Cultural Society. (2013). Studio 1398 Technical Specifications. Retrieved 312 , 2013, from Studio 1398: http://www.giculturalsociety.org/studio1398/wpcontent/uploads/2013/01/Studio-Technical-Specifications.pdf

Granville Island Cultural Society. (no date). The Waterfront Theatre. Waterfront Theatre. Vancouver, British Columbia, Canada. Retrieved 4 14, 2013, from http://www.waterfronttheatre.ca/wft/photos.htm

Granville Island Cultural Society. (No date). Waterfront Theatre. Retrieved 3 25, 2013, from Waterfront Theatre: http://www.waterfronttheatre.ca/

Greater Vancouver Professional Theatre Alliance. (2012). Fei and Milton Wong Experimental Theatre. Vancouver, British Columbia, Canada. Retrieved 3 4, 2013, from http://www.gvpta.ca/vancouver-theatre-guide/venue/fei-and-milton-wongexperimental-theatre-goldcorp-centre-for-the-arts/ 
Greater Vancouver Professional Theatre Alliance. (2013). Carousel Theatre. Vancouver, British Columbia, Canada. Retrieved 3 25, 2013, from http://www.gvpta.ca/vancouver-theatreguide/venue/carousel-theatre-studio/

Greater Vancouver Professional Theatre Alliance. (no date). Waterfront Theatre. Vancouver Theatre Guide. Vancouver, British Columbia, Canada. Retrieved 4 14, 2013, from http://www.gvpta.ca/vancouver-theatre-guide/venue/waterfront-theatre/

Havana Restaurant. (2013). Havana Restaurant. Retrieved 3 25, 2013, from http://www.havanarestaurant.ca/

Henriquez Partners Architects. (2013). York Theatre. Retrieved 3 18, 2013, from Henriquez Partners Architects: http://henriquezpartners.com/work/york-theatre/

Heritage Vancouver Society. (2008). 2008 Top 10 Endangered Sites - \#6 York (Alcazar) Theatre (1913). Retrieved 3 18, 2013, from Heritage Vancouver Society: http://www.heritagevancouver.org/topten/2008/topten2008_06.html

Hoekstra, G. (2012, 12 4). Theatre trio develops proposal for city art space in False Creek condo complex. The Vancouver Sun. Vancouver, British Columbia, Canada. Retrieved 3 31, 2013, from http://www.vancouversun.com/Theatre+trio+develops+proposal+city+space+False+Cre ek+condo+complex/7651806/story.html

Jewish Community Centre of Greater Vancouver. (2009). Norman Rothstein Theatre. Jewish Community Centre of Greater Vancouver. Vancouver, British Columbia, Canada.

Retrieved 4 4, 2013, from http://www.jccgv.com/content/norman-and-annetterothstein-theatre

Jewish Community Centre of Greater Vancouver. (2013). Norman Rothstein Theatre Technical Info. Retrieved 3 25, 2013, from Norman Rothstein Theatre:

http://www.normanrothsteintheatre.com/technical-info.php

Langara University College. (2013). Studio 58. Retrieved 3 28, 2013, from Studio 58: http://www.langara.bc.ca/studio-58/

Le Centre culturel francophone de Vancouver. (no date). Le Centre Mandat. Retrieved 314 , 2013, from Le Centre culturel francophone de Vancouver: http://lecentreculturel.com/index.php?option=com_content\&view=article\&id=26\&ltem $\mathrm{id}=8$ \&lang=en

Lee, J., \& Hall, N. (2012, 3 9). Vancouver Playhouse Theatre Company to close final curtain this Saturday. Retrieved 3 25, 2013, from The Vancouver Sun: http://www.vancouversun.com/entertainment/Vancouver+Playhouse+Theatre+Compa ny+close+final+curtain+Saturday/6279311/story.html

Lindsay, J. Exterior view of the Stanley Theatre showing advertising for "Duel in the Sun". City of Vancouver Archives. City of Vancouver Archives, City of Vancouver.

Matheson, B., \& Goldstein, L. (2010). Capitol Residences. Architects, Bingham Hill. Vancouver, British Columbia, Canada. Retrieved 4 14, 2013, from http://www.bharch.ca/projects/cat/169/id/63

McKinsley and Company. $(2009,10)$. A strategic and economic business for private and public sector investment in the arts in Canada. Retrieved 2 17, 2013, from Business for the Arts: http://www.businessforthearts.org/wp-content/uploads/2012/02/BftA-businesscase-for-funding-the-arts.pdf 
Mercer. (2012, December 4). 2012 Quality of Living worldwide city rankings - Mercer survey. Retrieved December 4, 2012, from Mercer: http://www.mercer.com/pressreleases/quality-of-living-report-2011

Metro Theatre Company. $(2012,816)$. Give your rump a rest metro has new seats. Metro Theatre. Vancouver, British Columbia, Canada. Retrieved 4 14, 2013, from http://metrotheatre.com/give-your-rump-a-rest-metro-has-new-seats/

Metro Theatre Vancouver. (2013). Rentals. Retrieved 4 1, 2013, from Metro Theatre: http://metrotheatre.com/rentals/

Metro Vancouver Arts and Culture. (2011). Studio 16 Venue Details. Retrieved 4 13, 2013, from Metro Vancouver Arts and Culture: http://www.maxguide.org/events/Pages/VenueDetails.aspx?VenuelD=121

Munro, K. (2011). Policy Report, Development and Building - CD-1 Rezoning and Heritage Revitalization Agreement at 639 Commercial. Vancouver: City of Vancouver.

Pacific Theatre. (2013). Pacific Theatre Rental Information. Retrieved 3 16, 2013, from Pacific Theatre: http://pacifictheatre.org/about/rentals

Pacific Theatre. (no date). About Us. Pacific Theatre. Vancouver, British Columbia, Canada. Retrieved 4 12, 2013, from http://pacifictheatre.org/about

Parks Canada. (1979, 11 15). Orpheum Theatre National Historic Site of Canada. Retrieved 4 12, 2013, from Canada's Historic Places: http://www.historicplaces.ca/en/rep-reg/placelieu.aspx?id=7645\&pid=0

Parks Canada. (2006, 3 29). Vogue Theatre National Historic Site of Canada. Retrieved 324 , 2013, from Canada's Historic Places: http://www.historicplaces.ca/en/rep-reg/placelieu. aspx?id=5117\&pid=0

Payne, J. (2010, 7 3). Vogue Theatre on Granville Street in Vancouver, BC. The Vancouver Sun. Vancouver, British Columbia, Canada. Retrieved 4 12, 2013, from http://www.vancouversun.com/Refurbished+Vogue+Theatre+hopes+host+events+annu ally/3228669/story.html

Performance Works. (2013). Rental Rates. Retrieved 3 12, 2013, from Performance Works: http://performanceworks.ca/pw/rentalrates.htm

Performing Arts Lodge Society. (2010). PAL Studio Theatre Technical Specifications and Theatre Rental Guidelines. Retrieved 3 30, 2013, from Performing Arts Lodge:

http://palvancouver.org.previewmysite.com/sites/default/files/PAL\%20Vancouver\%20S tudio\%20Theatre.Technical\%20Specifications\%20\&\%20Rental\%20Guidelines.February\% 202013_1.pdf

Plaza, B. (2007, 9). The Bilbao Effect Ten Years Later. Museum News, 13-15.

Punter, J. (2003). The Vancouver Achievement: Urban Planning and Design. Vancouver: Island Press.

Rickard, D. (2011, 6 28). The Orpheum Theatre Vancouver B.C. Flickr. Vancouver, British Columbia, Canada. Retrieved 4 1, 2013, from http://www.flickr.com/photos/danrickard/5988490225/

Rijn, J. v. (2013). Carousel Theatre. Vancouver, British Columbia, Canada. Retrieved 3 17, 2013, from http://en.wikipedia.org/wiki/File:Carouseloutside.jpg 
Roundhouse Community Arts and Recreation Centre. (2013). Performance Centre. Retrieved 3 25, 2013, from Roundhouse Community Arts and Recreation Centre:

http://roundhouse.ca/facilities-rentals/room-information/performance-centre/

Sandercock, L. (2006). An Anatomy of Civic Ambition in Vancouver: Towards Humane Density. In W. S. Saunders (Ed.), Urban Planning Today: A Harvard Design Magazine Reader (pp. 48-62). Minneapolis: University of Minnesota.

Savory Chef Catering. (no date). Performance Works. Savory Chef Catering. Vancouver, British Columbia, Canada. Retrieved 4 14, 2013, from http://www.savourychef.com/weddingvenue-event-venue/performance-works/

Savory Chef. (no date). Scotiabank Dance Centre. Savory Chef Catering. Vancouver, British Columbia, Canada. Retrieved 4 13, 2013, from http://www.savourychef.com/weddingvenue-event-venue/scotiabank-dance-centre/

Scotiabank Dance Centre. (2013). Faris Family Studio. Retrieved 3 30, 2013, from Scotiabank Dance Centre: http://www.thedancecentre.ca/faris_family_studio

Scotiabank Dance Centre. (2013). The Dance Centre. Retrieved 3 29, 2013, from Scotiabank Dance Centre: http://www.thedancecentre.ca/about_us/the_dance_centre

Setlist.fm. (No date). New York Theatre Vancouver. Retrieved 3 18, 2013, from Setlist.fm - The Setlist Wiki: http://www.setlist.fm/venue/new-york-theatre-vancouver-bc-canada63d6c687.html

Simon Fraser University. (2013). SFU Woodwards - About Us. Retrieved 3 25, 2013, from SFU Woodwards: http://sfuwoodwards.ca/index.php/about

Sinclair, L. (2005). Roundhouse Performance Centre. Centre of Expertise on Culture and Communities Cultural Facility Profile. Vancouver, British Columbia, Canada. Retrieved 4 14, 2013, from http://www.cultureandcommunities.ca/cecc/resources/cultural-facilityprofiles/artspace-north/roundhouse.html

Slack, E. (2009). Guide to Municipal Finance. Nairobi: United Nations Habitat.

Smith, J. (2011, 4 14). Scotiabank Dance Centre celebrates a decade of dancing in midair. Retrieved 3 30, 2013, from The Georgia Straight:

http://www.straight.com/arts/scotiabank-dance-centre-celebrates-decade-dancingmidair

Smith, T. N. (2008, 9 26). Kevin Addresses the Crowd. Flickr. Vancouver, British Columbia, Canada. Retrieved 3 25, 2013, from http://www.flickr.com/photos/nep/2897671269/

South Granville Business Improvement Association. (2013). Stanley Theatre. Retrieved 3 19, 2013, from South Granville: http://www.southgranville.org/history/stanley-theatre/

Stagecoach Theatre Arts Schools Canada. (2011, 6). End of year show 2011 - 'The Wizard of Oz' at The Cultch Theatre, Vancouver. Vancouver, British Columbia, Canada. Retrieved 412 , 2013, from http://www.stagecoachschools.ca/vancouverwestside/news/30529-end-ofyear-show-june-2011.html

Stanwick, S., \& Flores, J. (2007). Design City Toronto. Chichester: John Wiley and Sons.

Studio 1398. (2011, 9 11). Rental Rates. Retrieved 4 13, 2013, from Studio 1398 :

http://www.giculturalsociety.org/studio1398/wp-content/uploads/2012/03/RentalRates-STUDIO1398.pdf 
The Centre in Vancouver. (2007). The Centre in Vancouver for the Performing Arts. Vancouver, British Columbia, Canada. Retrieved 4 12, 2013, from http://www.centreinvancouver.com/history.php

The Centre in Vancouver for Performing Arts. (2007). Technical Specs. Retrieved 3 25, 2013, from The Centre in Vancouver for Performing Arts: http://www.centreinvancouver.com/technical_specs.php

The Vancouver East Cultural Centre. (2011, 10 19). The Cultch Today! Vancouver, British Columbia, Canada. Retrieved 4 13, 2013, from http://blog.thecultch.com/2011/10/backto-where-it-all-began-with-cultch-founder-chris-wootten/

The Vancouver East Cultural Centre. (2011, 1128$)$. The Many Faces of the Vancity Culture Lab. The Cultch Blog. Vancouver, British Columbia, Canada. Retrieved 4 12, 2013, from http://blog.thecultch.com/2011/11/the-many-faces-of-the-vancity-culture-lab/

The Vancouver East Cultural Centre. (2013). Our Story. Retrieved 3 18, 2013, from The Vancouver East Cultural Centre: http://www.thecultch.com/content/view/17/364/

The Vancouver East Cultural Centre. (2013). The Cultch Historic Theatre Rental Info. Retrieved 3 25, 2013, from The Vancouver East Cultural Centre: http://www.thecultch.com/content/view/194/288/

The Vancouver East Cultural Centre. (2013). The VanCity Culture Lab Rental Info. Retrieved 325 , 2013, from The Vancouver East Cultural Centre: http://www.thecultch.com/content/view/195/289/

The Vancouver East Cultural Centre. (2013). The York Theatre. Retrieved 3 18, 2013, from The Cultch: http://www.thecultch.com/content/view/295/431/

The Vogue Theatre. (2010). History. Retrieved 321 , 2013, from The Vogue Theatre: http://www.voguetheatre.com/history.php

Thoeny, M. (2011, 2 22). Queen Elizabeth Theatre interior from stage. Wikipedia. Vancouver, British Columbia, Canada. Retrieved 4 13, 2014, from http://commons.wikimedia.org/wiki/File:Queen_Elizabeth_Theatre_Vancouver_View_fr om_Stage.jpg

Trip Advisor. (2013). Firehall Arts Centre. Vancouver, British Columbia, Canada. Retrieved 4 1, 2013, from http://www.tripadvisor.com/Attraction_Review-g154943-d606742-ReviewsFirehall_Arts_Centre-Vancouver_British_Columbia.html

Vaclav, T. S. (2010, 2 16). Kanady Vancouver Neni jen Zimni Olympiada. Opera Plus. Vancouver, British Columbia, Canada. Retrieved 4 14, 2014, from http://operaplus.cz/list-z-kanadyvancouver-neni-jen-zimni-olympiada/

VanCity. (2010). Vancity loan supports the laughter created by the Vancouver TheatreSports League. Retrieved 3 12, 2013, from VanCity Social Purpose Real Estate: https://www.vancity.com/SharedContent/documents/impact/theatresports.pdf

VanCity Buzz Photo Pool. (n.d.). Roundhouse Community Centre. Flickr. Vancouver, British Columbia, Canada. Retrieved 4 12, 2013, from http://www.flickr.com/groups/vancitybuzz/pool/page8/

Vancouver Heritage Foundation. (2011, 3). 2011 Heritage Awards Nomination. Retrieved 3 19, 2013, from Vancouver Heritage Foundation: http://www.vancouverheritagefoundation.org/wpcontent/uploads/2013/01/Nominated-sites-March-2011.pdf 
Vancouver Playhouse Theatre Company. (2013). Vancouver Playhouse Theatre Company. Retrieved 4 1, 2013, from Vancovuer Playhouse Theatre Company: http://www.vancouverplayhouse.com/\#

Vancouver Symphony Orchestra. (2012, 10 17). Pyatt Hall. Facebook. Vancouver, British Columbia, Canada. Retrieved 4 14, 2014, from http://www.facebook.com/pages/PyattHall/418074344918607

Vancouver Symphony Orchestra. (2013). Orpheum Annex. Vancouver, British Columbia, Canada. Retrieved 4 1, 2013, from http://www.vancouversymphony.ca/venues/orpheum-annex/

Vancouver Symphony Orchestra. (2013). The Orpheum Theatre. Vancouver Symphony Orchestra. Vancouver, British Columbia, Canada. Retrieved 4 19, 2013, from http://www.vancouversymphony.ca/venues/orpheum-theatre/

Vancouver Symphony School of Music. (2013). About Us - History. Retrieved 3 18, 2013, from Vancouver Symphony School of Music: http://www.vsoschoolofmusic.ca/aboutus/history/vancouver-symphony-orchestra/

Vancouver Theatresports League. (2013). The Improv Centre. Retrieved 3 25, 2013, from Vancouver Theatresports League: http://www.vtsl.com/rentals/index.php

Wall Financial Corporation. (No date). Wall Centre False Creek. Retrieved 3 18, 2013, from Rennie Marketing Systems: http://www.rennierealty.com/vancouver-bcdevelopments/109-wall-centre-false-creek

Westbank. (2012). Woodward's. Vancouver, British Columbia, Canada. Retrieved 3 4, 2013, from http://www.westbankcorp.com/woodwards/completion.php

Wolodoko, M. (2011, 4 5). Jericho Arts Centre. Vancouver, British Columbia, Canada. Retrieved 4 14, 2013, from http://maxinewolodko.wordpress.com/2011/04/05/jericho-artscentre/

Woods, K. (2013, 125$)$. PAL Studio Theatre house hang. Flickr. Vancouver, British Columbia, Canada. Retrieved 4 15, 2013, from http://www.flickr.com/photos/93018181@N02/8455971729/

Woronkowicz, J., Joynes, D. C., Frumkin, P., Kolendo, A., Seaman, B., Gertner, R., et al. (2012). Set in Stone: Building America's New Generation of Arts Facilities 1994 - 2008. University of Chicago, Cultural Policy Centre. Chicago: University of Chicago. 